\author{
Universidade de São Paulo \\ Instituto de Energia e Ambiente \\ Programa de Pós-Graduação em Ciência Ambiental
}

\begin{abstract}
A política climática da cidade de São Paulo (2001-2016): análise da ação pública
\end{abstract}

Guilherme Barbosa Checco

São Paulo

2018 


\title{
A política climática da cidade de São Paulo (2001-2016): análise da ação pública
}

\author{
Guilherme Barbosa Checco
}

Dissertação apresentada para obtenção do título de Mestre em Ciências junto ao Programa de Pós-graduação em Ciência Ambiental do Instituto de Energia e Ambiente da Universidade de São Paulo.

Orientador: Prof. Dr. Eduardo de Lima Caldas

Versão original

São Paulo

2018 
Autorizo a reprodução e divulgação total ou parcial deste trabalho, por qualquer meio convencional ou eletrônico, para fins de estudo e pesquisa, desde que citada a fonte.

Checco, Guilherme Barbosa.

A política climática da cidade de São Paulo (2001-2016): análise da ação pública. / Guilherme Barbosa Checco; orientador: Eduardo de Lima Caldas. - São Paulo, 2018.

$177 \mathrm{f} .:$ il; $30 \mathrm{~cm}$.

Dissertação (Mestrado em Ciência Ambiental) - Programa de PósGraduação em Ciência Ambiental - Instituto de Energia e Ambiente da Universidade de São Paulo.

1. Mudança climática - São Paulo. 2. Sociologia política. 3. Políticas públicas - I. Título.

Elaborado por Maria Penha da Silva Oliveira CRB-8/6961 
Nome: CHECCO, Guilherme Barbosa

Título: A política climática da cidade de São Paulo (2001-2016): análise da ação pública

Dissertação apresentada para obtenção do título de Mestre em Ciências junto ao Programa de Pós-graduação em Ciência Ambiental do Instituto de Energia e Ambiente da Universidade de São Paulo.

Aprovado em:

\section{Banca Examinadora}

Prof. Dr. Instituição:

Julgamento: Assinatura:

Prof. Dr. Instituição:

Julgamento: Assinatura:

Prof. Dr. Instituição:

Julgamento: Assinatura:

Prof. Dr. Instituição:

Presidente: Assinatura: 


\section{Agradecimentos}

Em primeiríssimo lugar - não poderia ser diferente -, devo agradecer o incomensurável e incondicional apoio psicológico, moral e financeiro que meus pais sempre deram a mim e ao meu processo educacional, apoio este que sempre esteve disponível de maneira constante e sem o qual jamais conseguiria chegar onde cheguei e pretendo chegar. À minha mãe, Maria Inês Barbosa Checco, e ao meu pai, Valdir Checco (in memoriam), meu mais sincero e amoroso muito obrigado.

Em seguida, deixo registrado aqui meu agradecimento ao Prof. Dr. Eduardo de Lima Caldas. Nossa relação teve início, assim como o figurino manda, enquanto orientador e educando. Meu sentimento é que, ao longo do mestrado, superamos as barreiras formais que a academia tenta impor e, mantendo o rigor acadêmico, criamos uma relação de confiança. Edu - maneira como a amizade construída me permite chamá-lo - é um intelectual de primeira linha. Sem seus conselhos e sem sua orientação, teria tido dificuldades muito maiores no árduo trabalho de compreender, ao menos em partes, as complexidades da ação pública contemporânea e as relações sociais que a permeiam. Nossas conversas nas padarias e cafés do Higienópolis, além de contribuírem diretamente para os avanços da dissertação, permitiram igualmente expandir minha visão sobre a política brasileira. Espero que ainda sigamos juntos, de maneira ou outra, em outras empreitadas da vida.

Aos amigos da vida, sem os quais a vida perde graça e espontaneidade. Os momentos junto a eles permitiram espairecer as ideias e reunir energias indispensáveis para enfrentar as adversidades do cotidiano.

À Juliana Cassano Cibim, ex-chefe e sempre amiga, que me apresentou ao Prof. Eduardo e que me deu forças para tomar a decisão inicial de mergulhar no mestrado.

Ao Instituto Democracia e Sustentabilidade, em especial às figuras de João Paulo R. Capobianco e Fábio de Almeida Pinto que estiveram presentes durante o processo do mestrado e compreenderam os momentos de concentração que necessitei.

A todos os entrevistados que dispuseram de seu tempo para resgatar elementos importantes dos acontecimentos aqui relatados. À Mônica Ribeiro, que gentilmente cedeu a primeira (e longa) entrevista, assim como ajudou a propor ajustes no roteiro de entrevistas e a estabelecer contato com alguns dos demais entrevistados. Uma memória especial ao falecido Volf Steinbaum que, 
juntamente com sua esposa Ignez e sua família, tão gentilmente me receberam em sua residência em Dourados, Mato Grosso do Sul.

Aos integrantes da banca de qualificação, Profa. Dra. Neli Aparecida de Mello-Théry e Prof. Dr. Mário Lúcio de Ávila, pelas sugestões fundamentadas que fizeram e que contribuíram para aperfeiçoar o trabalho em curso.

À Coordenação de Aperfeiçoamento de Pessoal de Nível Superior - Brasil (CAPES) pelo apoio à realização deste trabalho. 
"Comprendre une politique publique, demande donc de décrypter les sens et les projets sous-jacents à chaque action qui la façonne, ainsi que les modes d'articulation entre leurs acteurs, entre leurs actes."

Gilles Massardier 


\section{Resumo}

CHECCO, Guilherme Barbosa. A política climática da cidade de São Paulo (2001-2016): análise da ação pública. 2018. 177 p. Dissertação (Mestrado em Ciência Ambiental) - Programa de Pós-Graduação em Ciência Ambiental - Instituto de Energia e Ambiente da Universidade de São Paulo, São Paulo, 2018.

As mudanças climáticas impõem um conjunto de desafios à sociedade contemporânea. Nesse sentido, esta dissertação trata das mudanças climáticas a partir da abordagem dos governos locais e, mais especificamente, da experiência da cidade de São Paulo. A política climática permitiu que o município paulistano exercesse um protagonismo no cenário nacional e regional, além de uma inserção internacional. A cidade promulgou em junho de 2009, antes do estado de São Paulo e da União, a lei que criou e institucionalizou sua política de mudança do clima. O recorte cronológico considerou os mandatos dos prefeitos Marta Suplicy (PT), de 2001 a 2004; José Serra (PSDB), de 2005 a 2006; Gilberto Kassab (PFL/DEM/PSD), de 2006 a 2012; e Fernando Haddad (PT), de 2013 a 2016. Esse período foi analisado a partir do referencial teórico da sociologia política, considerando especificamente a figura do mediador de políticas públicas e os instrumentos da ação pública. Em termos metodológicos foi realizada uma revisão bibliográfica não sistemática, pesquisas em legislações e periódicos da época e a aplicação de questionário semiestruturado em entrevistas com atores-chave. O questionamento central foi: o que permitiu que a cidade de São Paulo exercesse um protagonismo no campo das políticas públicas em mudanças climáticas no Brasil? A busca pela resposta a essa pergunta indicou que um conjunto de instrumentos da ação pública local começou a ser implementado pelo menos desde 2003 e, a partir do momento em que os valores das mudanças climáticas passaram a representar a principal referência das ações da Secretaria do Verde e Meio Ambiente (SVMA), uma série de ações intersetoriais ganharam força. Eduardo Jorge exerceu uma liderança importante nesse processo, sendo o Secretário de Meio Ambiente mais longevo. Entretanto, quando um novo governo assumiu o poder em São Paulo a partir de 2013, a política climática perdeu força e sofreu retrocessos.

Palavras-chave: mudanças climáticas; cidade de São Paulo; governos locais; sociologia política; mediador de política pública

\section{Abstract}


CHECCO, Guilherme Barbosa. The climate policy of the city of São Paulo (2001-2016): analysis

of the public action. 2018. 177 p. Dissertation (Master in Environmental Science) - Post Graduate Program of Environmental Science, Universidade de São Paulo, São Paulo, 2018.

The climate change imposes a set of challenges to the contemporary society. This dissertation considers the climate change from the local governments approach and, more specifically, the São Paulo's city experience. The climate policy allowed the city to play a leading role at the national regional scenario, besides an international insertion. The city has promulgated in June 2009 the law that created and institutionalized its climate change policy, before the State of São Paulo and the Union. The period analyzed considered the mandates of mayors Marta Suplicy (PT) from 2001 to 2004, José Serra (PSDB) in 2005 and Gilberto Kassab (PFL/DEM/PSD) from 2006 to 2012, and Fernando Haddad (PT) from 2013 to 2016. This period was analyzed from the theoretical reference of the political sociology perspective, considering specifically the figure of the public policies mediator and public action instruments. The methodology adopted was based on nonsystematic bibliographic review, researches in legislation and journals, and the application of semi structured questionnaire on interviews with key actors. What allowed the city of São Paulo to play a leading role in the field of public policies on climate change in Brazil? The quest for the answer to this question indicated that a set of local public action instruments have been in place since at least 2003 and, as climate change values have come to represent the main reference of SVMA actions, a series of intersetorial actions gained strength. Eduardo Jorge has an important leadership in this process, being the environmental secretary during the longer analyzed period. However, when the new São Paulo's government takes place from 2013, climate change policy loses strength and has setbacks.

Key-words: climate change; city of São Paulo; local governments; political sociology; public policies mediator 


\section{Lista de imagens e quadros}

Quadro 1. Relação dos prefeitos e secretários do meio ambiente da cidade de São Paulo ...........54

Quadro 2. Produções acadêmicas sobre a política de mudanças climáticas do município de São

Paulo

.56

Quadro 3. Tabela das ideias redes, fóruns e instrumentos do contexto internacional prévio........64

Quadro 4. Tabela com a ideia, os atores, os instrumentos, as redes e as ações do governo Marta

Suplicy (2001-2004).

Quadro 5. Tabela com a ideia, os atores, os instrumentos, as redes, o fórum e as ações do governo

José Serra (2005-2006)

Quadro 6. Tabela com a ideia, os atores, os instrumentos, os fóruns e as ações do governo Gilberto Kassab (2006-2012).

100

Quadro 7. Tabela com a ideia, os atores, os instrumentos e as ações do governo Fernando Haddad (2013-2016)

Quadro 8. Percurso metodológico.

Tabela 1. Emissões totais de GEEs no município de São Paulo

Figura 1. Categorias de análise consideradas na dissertação.....................................................26



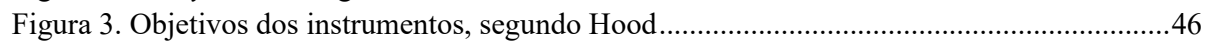

Figura 4. Objetivos dos instrumentos, segundo Lascoumes e Le Galès........................................47

Figura 5. Componentes dos instrumentos da ação pública, segundo Lascoumes e Le Galès .......48

Figura 6. Variáveis que influenciam a escolha dos instrumentos (Lascoumes e Simard).............50

Figura 7. Categorias de análise, segundo as contribuições teóricas ...............................................52

Figura 8. Linha do tempo (1988-2016) com os destaques da política climática paulistana...........58

Figura 9. Capa da revista Time em outubro de 1987 ...................................................................6

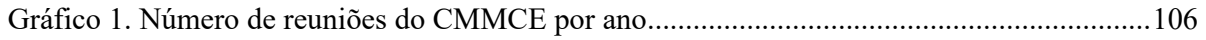




\section{Lista de abreviaturas e siglas}

Abrava - Associação de fabricantes de equipamentos de refrigeração e aquecedores solares

Anfavea - Associação Nacional dos Fabricantes de Veículos Automotores

AR - Assessment Reports

CADES - Conselho Municipal do Meio Ambiente e do Desenvolvimento Sustentável

CCP - Cities for Climate Protection

CMMCE: Comitê Municipal sobre Mudanças Climáticas e Economia Sustentável

CO2e - Dióxido de carbono equivalente

COP - Conference of the Parties

COPPE/UFRJ - Instituto Alberto Luiz Coimbra de Pós-Graduação e Pesquisa de Engenharia, da Universidade Federal do Rio de Janeiro

DEM - Partido Democratas

EMPLASA - Empresa Paulista de Planejamento Metropolitano S.A.

EJ - Eduardo Jorge

FHC - Fernando Henrique Cardoso

Fiesp - Conselho Municipal do Meio Ambiente e do Desenvolvimento Sustentável

GEEs - Gases de Efeito Estufa

GgCO2e - Giga grama de dióxido de carbono equivalente

IDS - Instituto Democracia e Sustentabilidade

INDC - Intended Nationally Determined Contributions

IPCC - Intergovernmental Panel on Climate Change

ISCI - International Solar Cities Initiative

MDL - Mecanismo de Desenvolvimento Limpo

MPE - Ministério Público Estadual

ONU - Organização das Nações Unidas

PAVs - Programa Ambientes Verdes e Saudáveis 
PEMC/SP - Política Estadual de Mudanças Climáticas de São Paulo

PFL - Partido da Frente Liberal

PL - Projeto de Lei

PMMC/SP - Política Municipal de Mudanças Climáticas da cidade de São Paulo

PNMC - Política Nacional de Mudanças Climáticas

PNUMA - Programa das Nações Unidas para o Meio Ambiente

PPB - Partido Progressista Brasileiro

PPS - Partido Popular Socialista

PPCDAm - Plano de Ação para Prevenção e Controle do Desmatamento na Amazônia Legal

PROS - Partido Republicano da Ordem Social

PR - Partido da República

PRP - Partido Republicano Progressista

PSC - Partido Social Cristão

PSD - Partido Social Democrático

PSDB - Partido da Social Democracia Brasileira

PSF - Programa Saúde Família

PSOL - Partido Socialismo e Liberdade

PT - Partido dos Trabalhadores

PV - Partido Verde

Rio 92 / Eco 92 - Conferência das Nações Unidas sobre o Meio Ambiente e o Desenvolvimento realizada no Rio de Janeiro em 1992

Sinduscon - Sindicato da Construção Civil

SMA - Secretaria Estadual de Meio Ambiente

SMRI - Secretaria Municipal de Relações Internacionais

SMS - Secretaria Municipal de Saúde

SS - Secretaria Estadual de Saúde 
SVMA - Secretaria do Verde e Meio Ambiente

TCM - Tribunal de Contas do Município

UCLG - United Cities and Local Governments

UMAPAZ - Universidade Aberta do Meio Ambiente e da Cultura de Paz

UNFCCC - United Nations Framework Convention on Climate Change

UTE - Unidade Térmica de Energia

WWF - World Wild Fund 


\section{Sumário}

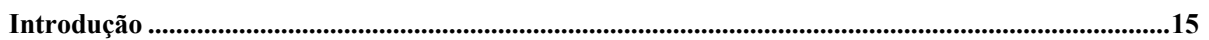

1. Capítulo 1 - Ação pública e as perspectivas teóricas ……………………………..............................25

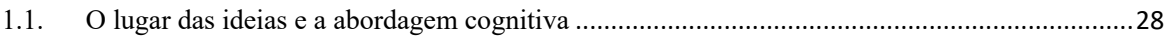

1.2. Os múltiplos atores nas políticas públicas: diferentes nomes para o mesmo fenômeno? .............33

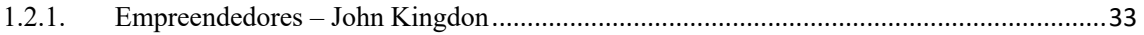

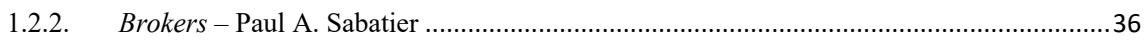

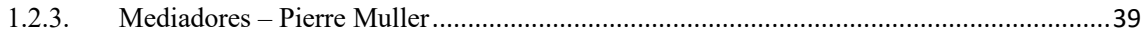

1.3. As relações e as redes de políticas públicas............................................................................... 42

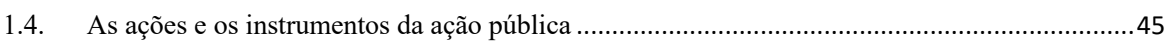



2. Capítulo 2 - A política climática paulistana durante quatro governos: as ideias, os atores, as

relações e as ações ...........................................................................................................................................54

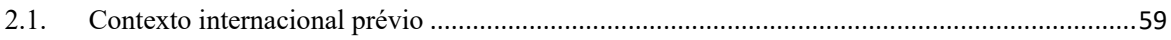

2.2. Gestão da prefeita Marta Suplicy (PT) (2001-2004) ................................................................64

2.3. Gestão do prefeito José Serra (PSDB) (2005-2006) ................................................................72

2.4. Gestão do prefeito Gilberto Kassab (PFL/DEM/PSD) (2006-2012) ........................................... 80

2.4.1. Os dois primeiros anos da gestão Kassab: Ações concretas na agenda climática.................80

2.4.2. 2008: ano eleitoral e avanços na construção da política climática local...............................86

2.4.3. A institucionalização da política climática paulistana a partir de uma lei específica (2009) 91

2.4.4. Após a promulgação da Política Municipal de Mudança do Clima......................................94

2.4.5. Considerações preliminares do capítulo: balanço do governo Gilberto Kassab ..................97

2.5. Gestão do prefeito Fernando Haddad (PT) (2013-2016) ......................................................101



4. Capítulo 3 - Análise do caso de São Paulo a partir das entrevistas............................................114

5.1. Quando as mudanças climáticas entraram na agenda? ...............................................................114

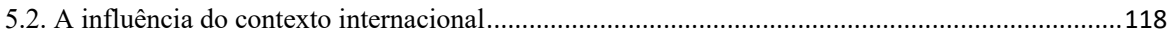

5.3. O mediador, os instrumentos e a rede da política climática paulistana .........................................122

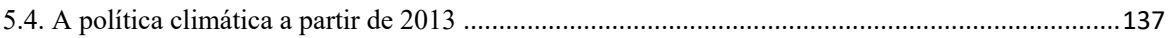

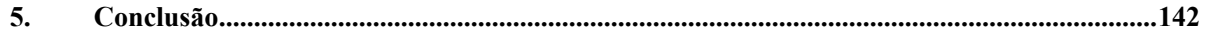




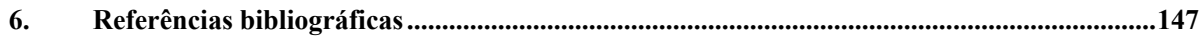



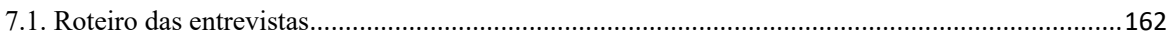



7.3. Atores que participaram da construção da política paulistana de mudanças climáticas. 164 


\section{Introdução}

Ao observar o noticiário nacional e internacional é possível constatar que as mudanças climáticas estão paulatinamente ocupando espaços cada vez maiores em relação às preocupações da sociedade. As vozes que negam a existência das mudanças climáticas, ou que semeiam dúvidas em relação ao papel da ação humana ainda existem, conforme o documentário "Merchants of Doubt" (2014) relata. Entretanto, as pesquisas científicas vêm indicando, com uma precisão cada vez mais apurada, as causas, os efeitos e as projeções advindos das alterações que a ação humana gera nos ciclos biogeoquímicos (IPCC, 2013; MIT, 2016; USGCRP, 2017).

As projeções do Painel Intergovernamental sobre Mudanças Climáticas (IPCC) indicam que os extremos climáticos serão parte do cotidiano da sociedade global:

\footnotetext{
"A influência humana no sistema climático é notória. Isso se nota a partir do aumento da concentração de gases de efeito estufa na atmosfera, absorção de raios radioativos na atmosfera, aquecimento atmosférico e compreensão do sistema climático." (Fifth Assessment Report, Summary for Policymakers, 2014, p. 15 - Tradução do autor).
}

Tal conhecimento científico compartilhado entre as comunidades epistêmicas tem o significativo desafio de adentrar o campo sociopolítico. Nesse sentido, vale dizer que, para as soluções empíricas poderem ser debatidas e implementadas, é necessário um esforço de comunicação social eficiente e clara, que envolva tanto a sociedade como um todo quanto os agentes políticos.

Em dezembro de 2015 foi realizado o $21^{\circ}$ encontro da Conferência das Partes (COP), dessa vez em Paris. Essa reunião ocorre no âmbito da Convenção-Quadro das Nações Unidas sobre Mudanças Climáticas (UNFCCC, na sigla em inglês), criada a partir das negociações da Conferência das Nações Unidas sobre o Meio Ambiente e o Desenvolvimento, mais conhecida como Rio 92 . Esse fórum representa o principal espaço de negociação política a respeito das mudanças climáticas.

Entre os principais resultados da COP-Paris está o compromisso de limitar o aquecimento global em $2^{\circ} \mathrm{C}$ em relação à era préindustrial, com esforços para alcançar a meta de $1,5^{\circ} \mathrm{C}$ até 2020 . Essas metas foram estipuladas com base nas descobertas científicas que afirmam que, caso esses limites não sejam alcançados, teremos de enfrentar danos irreversíveis. Os 195 países integrantes da UNFCCC 
assumiram esse compromisso, inclusive o Brasil. Esse momento vivenciado durante a COP-Paris representou, então, um exemplo singular de união entre o conhecimento científico, os compromissos dos agentes políticos, uma significativa cobertura da mídia e uma relativa sensibilização social.

O pesquisador brasileiro José Eli da Veiga (2015) classifica as mudanças climáticas como o maior desafio global da sociedade contemporânea, acima de qualquer outra agenda da sustentabilidade. Os desafios relacionados às mudanças climáticas são elementares para o futuro da humanidade e, por isso, o autor ressalta seu caráter "civilizatório". "Mais do que um problema ambiental, a mudança climática é hoje o maior dos problemas globais de longo alcance da época atual, sejam eles econômicos, políticos ou de segurança" (DA VEIGA, 2015, p. 161)

Existem distintas perspectivas a respeito do enfrentamento desse desafio no âmbito da política. O exemplo da COP-Paris retrata uma maneira, a partir das negociações entre Estados-nação em um contexto internacional. Porém, dada a complexidade do tema, outras perspectivas são necessárias e indispensáveis para poder avançar como, por exemplo, a tradução dos acordos internacionais em políticas reais em cada um dos países e, também, o papel dos governos subnacionais no enfrentamento desse desafio.

Segundo Giddens (2010), a construção das soluções passa necessariamente pelo campo político. Assim, Giddens defende a ideia de que é imprescindível que haja uma ação política articulada nos diferentes níveis - internacional, nacional, regional e local - para que a humanidade tenha chances reais de limitar os impactos das mudanças climáticas e conseguir se adaptar a contextos climáticos diferentes. Sem negar a importância de determinados atores, tais como a academia, a iniciativa privada e a sociedade civil organizada, Giddens afirma que uma real mudança de paradigma depende essencialmente da ação do governo e do Estado. Entre as tarefas que o "Estado facilitador" deve executar Giddens destaca o papel das lideranças políticas e os estímulos que a ordem política emite para as demais esferas, como ao aplicar o princípio "poluidor-pagador".

As considerações de Giddens auxiliam na compreensão do processo de construção das políticas climáticas no mundo. Notadamente, foram os Estados-nação que começaram a se organizar, a criar instituições e fóruns para tratar do tema das mudanças 
climáticas. Essa característica ainda persiste na atualidade, muito por conta da relevância desses atores, da sua capacidade de articulação e seu poder econômico. Ainda assim, é possível notar um movimento de organização e reivindicação do papel dos governos subnacionais nessa agenda. Nesse sentido, a presente dissertação tem como proposta compreender o campo das mudanças climáticas a partir do prisma dos governos locais.

A primeira justificativa para defender a abordagem a partir dos governos locais é o fato de que o mundo é um local cada vez mais urbanizado e as projeções indicam que $66 \%$ da população mundial será urbana até 2050. No Brasil, o censo populacional de 2010 indica que 160 milhões de brasileiros viviam em área urbana, montante que representava algo em torno de $85 \%$ de toda população brasileira.

Juntamente com o argumento da urbanização, existe um conjunto vasto de literatura que compartilha do entendimento de que é importante que os governos locais e regionais também desempenhem funções centrais na construção de soluções para o aquecimento global, embasando o argumento sobretudo em justificativas a respeito da governança desse "sistema".

É extensa a literatura que analisa especificamente as oportunidades, as necessidades e os desafios para que os governos locais sejam de fato um ator relevante na política de mudança do clima (BULKELEY e BETSILL, 2003; BETSILL e BULKELEY, 2006; TOLY, 2008; OSTROM, 2009; MARTINS e FERREIRA, 2011; OSTROM, 2012; ERICKSON e TEMPEST, 2014; KAHN e BRANDÃO, 2015; ARUP, 2015). Entre esses autores pode-se destacar algumas ideias gerais dessa produção acadêmica.

Nota-se que a produção intelectual que investiga a participação das cidades na agenda das mudanças climáticas é bastante recente, especialmente quando comparada com as ações empíricas que ocorreram no âmbito do sistema internacional, tais como a criação do IPCC e da UNFCC, em 1988 e 1992, respectivamente. A publicação mais antiga considerada no universo de análise da revisão de literatura desta dissertação é do ano de 2003, e nela encontra-se a passagem que ressalta a falta de demais produções com o mesmo enfoque: "Cities and climate change is the first in-depth and interdisciplinar analysis of the role of cities in adressing climate change and illustrates the multilevel nature of climate change governance” (BUKELEY e BETSILL, 2003). 
A maioria da literatura que trata da atuação das cidades na agenda climática parte da mesma premissa e do mesmo entendimento: a de que um mundo cada vez mais urbanizado trará consequências cruciais para as políticas de combate às mudanças climáticas. As afirmações que decorrem desse diagnóstico variam conforme o enfoque de cada autor, mas tem como cerne final assumir que não é possível desenvolver estratégias de mitigação das mudanças climáticas e de adaptação a elas sem considerar os impactos e as ações locais.

Entre os argumentos utilizados para reforçar a importância dos governos locais destaca-se a observação de que os acordos internacionais não são suficientes para lidar com a complexidade e a diversidade de desafios que o aquecimento global nos impõe. Nesse sentido, a atuação local deve ser compreendida como mais um agente que pode somar esforços com os atores internacionais. Elinor Ostrom, cientista política estadunidense, é uma das principais representantes dessas ideias. Ostrom considera que o desafio de construir políticas sustentáveis, entre elas aquelas relacionadas às mudanças climáticas, é de tamanha grandeza que as decisões tomadas, sobretudo no âmbito da COP, envolvendo quase que unicamente os governos nacionais, não seriam suficientes: “We cannot rely on singular global policies to solve the problem of managing our common resources" (OSTROM, 2012, p. 1).

Em um artigo anterior, datado de 2009, Ostrom cunhou o termo "governança policêntrica" para trabalhar exatamente com a ideia de que a política e seus agentes devem trabalhar com os desafios de mitigação e adaptação quanto às mudanças climáticas de uma maneira descentralizada, a partir da qual os acordos internacionais, os governos nacionais, regionais e locais possam todos somar esforços e compartilhar experiências.

Um segundo argumento que surge nessa literatura é o de que o conteúdo dos acordos internacionais deve encontrar respaldo, ser cumprido e adaptado tanto pelas políticas nacionais quanto por aquelas criadas e implementadas pelos demais entes locais. Nessa perspectiva, Kahn e Brandão ressaltam em artigo escrito em novembro de 2015, às vésperas da COP-Paris, a necessidade de que, no âmbito das negociações internacionais, as estratégias nacionais (chamadas de INDCs, ou Intended Nationally Determined Contributions) estejam integradas com as múltiplas ações dos governos locais de seus respectivos países. No contexto brasileiro, as autoras sublinham o potencial dos setores de construção, transporte e resíduos. 
Several cities in Brazil are already undertaking ambitious climate action. (...) Moreover, city leaders can support the national government in pushing for a better international climate agreement, because cities are now playing a central role in policies and actions related to climate change impacts (Kahn e Brandão, 2015, p. 16).

Outra reflexão encontrada na literatura que também trabalha com a atuação de governos locais nas problemáticas envolvendo o aquecimento global faz referência à possibilidade de que, em escalas menores, seja possível implementar, testar e avaliar melhor determinadas políticas, além de possibilitar a troca de experiências entre diferentes localidades. Bulkeley e Betsill (2003), Betsill e Bulkeley (2006), Ostrom (2009) e Martins e Ferreira (2011) apontam para a possibilidade de, em níveis locais, serem testadas ações e políticas com mais facilidade, uma vez que os custos são menores em relação a escalas maiores e a capacidade de assertividade é maior, pois se conhece melhor as características daquele território: “(...) it would be better to self-consciously adopt a polycentric approach to the problem of climate change in order to gain the benefits at multiple scales as well as to encourage experimentation and learning from diverse policies adopted at multiple scales" (OSTROM, 2009, p. 32).

Ainda que os governos locais não sejam necessariamente envolvidos nos debates e nas construções de estratégias para combater o aquecimento global, Ostrom (2012) identifica que já existem várias ações acontecendo de maneira orgânica em diversas cidades do mundo. Nota-se, então, que se trata de uma realidade já em curso e, portanto, importante de ser compreendida.

Somado aos argumentos dos autores citados, existe também um número cada vez maior de organizações que estimulam e/ou organizam a participação de governos locais na construção de políticas climáticas, seja capacitando seus agentes, seja possibilitando um ambiente de troca de experiência entre atores de diferentes países. Nesse sentido, pode-se destacar a atuação da Rede de Governos Locais pela Sustentabilidade (ICLEI, na sigla em inglês) e do C40 Cities.

A Rede de Governos Locais pela Sustentabilidade (ICLEI) é uma organização internacional que busca promover a ação de governos locais em prol da sustentabilidade global. Por sua vez, o C40 Cities - Climate Leadership Group é uma articulação transnacional de prefeitos de diversos países que conta com a participação de mais de 80 cidades, representando cerca de 600 milhões de habitantes e um quarto do PIB mundial. 
Considerando a importância da agenda das mudanças climáticas e a abordagem a partir de governos locais, a presente dissertação elegeu o caso da cidade de São Paulo, com cerca de 12 milhões de habitantes - número estimado para o ano de 2015 (IBGE) - e considerada uma das poucas megacidades do mundo presente em uma região metropolitana com cerca de 20 milhões de habitantes, como seu objeto de estudo. Além da grandiosidade em termos de urbanização e sua importância econômica na América Latina, a cidade de São Paulo foi protagonista na incorporação do discurso das mudanças climáticas, na institucionalização dessa política e na implementação de ações.

Do ponto de vista da emissão de gases de efeito estufa, São Paulo também é relevante. A cidade conta com uma frota de cerca de 8 milhões de veículos, uma média aproximada de um veículo para cada dois habitantes.

Segundo o último inventário de emissões de gases de efeito estufa do município de São Paulo, publicado em novembro de 2013, a cidade emitiu $15.115 \mathrm{GgCO}_{2} \mathrm{e}^{1} \mathrm{em} 2009$, sendo o setor de energia a principal fonte emissora. A cidade encontra-se, nesse sentido, em uma situação de alta vulnerabilidade frente aos impactos das mudanças climáticas, tais como enchentes e deslizamentos de terra provenientes de chuvas mais intensas.

A RMSP é uma das realidades climáticas urbanas mais críticas e insuficientemente estudadas no Brasil. (...) A crescente urbanização das periferias atuando em sinergia com o aquecimento global projeta que eventos com grandes volumes de precipitações pluviométricas irão ocorrer com mais frequência no futuro, abarcando cada vez uma maior área geografica da RMSP (Nobre et al., 2010, pgs. 10-11).

Em junho de 2009 a cidade instituiu sua Política Municipal de Mudança do Clima (PMMC) a partir da Lei Municipal n. 14.933. O momento era oportuno, uma vez que em dezembro daquele ano aconteceria a COP 15 em Copenhagen, na Dinamarca, e havia um debate muito intenso sobre a agenda climática em diversos fóruns. Mais do que isso, a aprovação da política municipal em junho de 2009 credenciava e legitimava a cidade de São Paulo, dando força política para ela. Nem o governo federal tampouco o governo estadual de São Paulo tinha uma política específica de mudanças climáticas.

${ }^{1}$ Giga grama de dióxido de carbono equivalente, unidade de medida correspondente a mil toneladas. 
Porém, o protagonismo paulistano não se limitou a uma mera questão de ordem cronológica de legislação. Por isso, é exatamente essa construção que a presente dissertação se propôs a investigar, com um recorte histórico que analisará o período de quatro mandatos.

O primeiro mandato foi de Marta Suplicy, prefeita eleita pelo Partido dos Trabalhadores (PT), que assumiu o poder entre 2001 e 2004. Nesse período, estiveram à frente da Secretaria do Verde e Meio Ambiente (SVMA) os secretários Stela Goldenstein e Adriano Diogo.

A segunda gestão na Prefeitura teve início em 2005, quando José Serra (PSDB) venceu o pleito contra a antiga prefeita, que tentava a reeleição. Entretanto, Serra deixou o cargo no início de 2006 para disputar o cargo de governador do estado, com o seu vice assumindo, então, o seu lugar, Gilberto Kassab, à época filiado ao Partido da Frente Liberal (PFL). Kassab se manteve no cargo de prefeito até 2012, vencendo Marta Suplicy no meio desse percurso nas eleições de 2008, quando era filiado ao Democratas (DEM) Durante os oito anos do segundo e terceiro mandato em análise pela presente dissertação, Eduardo Jorge foi o secretário da Secretaria do Verde e Meio Ambiente da cidade de São Paulo.

Por fim, o último governo foi de Fernando Haddad (PT), iniciado em 2013 e concluído em 2016. Durante seu mandato, Haddad contou com a participação de três diferentes secretários na SVMA: Ricardo Teixeira, Wanderley do Nascimento e José Tadeu Candelária.

Ainda que as mudanças climáticas representem uma temática transversal, que incide desde a política de saneamento até a de transporte, foi a SVMA a pasta que historicamente liderou essa agenda na gestão paulistana. Por causa disso é dado o devido destaque a essa secretaria na descrição inicial do recorte histórico.

Diante desse contexto, a pergunta que orienta a presente pesquisa é: o que permitiu que a cidade de São Paulo exercesse um protagonismo no campo das políticas públicas em mudanças climáticas no Brasil? A proposição preliminar é que o contexto internacional teve uma influência significativa no processo local paulistano, de modo que favoreceu positivamente a liderança de 
Eduardo Jorge nas ações coordenadas pela SVMA. Ainda, assim como o fator cognitivo foi relevante para os avanços da política climática paulistana, este igualmente foi decisivo para seu enfraquecimento a partir de 2013.

O ferramental teórico selecionado para auxiliar na compreensão do estudo de caso da cidade de São Paulo representa um eixo central de todo o desenvolvimento da dissertação. A análise da ação pública, notadamente do caso das políticas da cidade de São Paulo sobre mudanças climáticas, será desenvolvida a partir do aporte da sociologia política, mais especificamente da escola francesa. A opção pela sociologia política se deve ao fato de acreditar que esta traz contribuições significativas para o campo da Ciência Ambiental, no qual esta dissertação se insere, além de permitir lançar um olhar para um fenômeno social de maneira distinta e complementar em relação às demais produções acadêmicas já existentes.

As produções de Pierre Muller (1990) e Gilles Massardier (2011) apresentam aportes que permitem observar um período de tempo mais longo e, concomitantemente, considerar elementos cognitivos, interpretando a ação pública, portanto, como ações repletas de interesses e valores não explícitos. Peter Hall e Rosemary Taylor (1996) e Bruno Palier e Yves Surel (2005) aportam teoricamente a partir dos chamados três neoinstitucionalismos, chamando atenção para as ideias, os interesses e as instituições e suas respectivas e diferentes temporalidades. Por fim, as diferentes produções de Patrick Le Galès, Pierre Lascoumes e Louis Simard partem da definição de que a ação pública é um espaço sociopolítico construído a partir de instrumentos.

Uma das primeiras etapas deste trabalho foi fazer a revisão da produção acadêmica que também pesquisa a construção da agenda climática na cidade de São Paulo. Entre as produções identificadas é importante ressaltar a contribuição de duas delas: a tese de doutorado de Rachel Birderman Furriela, feita na FGV, no âmbito da Administração Pública, e a dissertação de mestrado de Adalberto Gregório Back, na UFSCar, em Ciência Política.

Na produção de Furriela (2011), a mais antiga entre as selecionadas, nota-se que sua proposta de trabalho é analisar um processo bastante recente, ou seja, somente após dois anos da publicação da Política Municipal de Mudança Climática, em 2009. Seguramente esse contexto permite alguns ganhos, como as memórias mais certeiras dos entrevistados e a possibilidade de entrar em detalhes do 
processo de construção. Em contrapartida, há limites na observação dos desdobramentos da própria política, uma vez que esta ainda não teve tempo necessário para amadurecimento e compreensão por parte da sociedade.

A partir da Administração Pública, a autora tem um foco mais especial para investigar como a participação pública se desenvolve no processo de construção de políticas subnacionais e, para isso, elege o processo de construção da política municipal de São Paulo para mudanças climáticas como seu estudo de caso. Considerando que seu referencial teórico está centrado na discussão a respeito da qualidade da participação pública, seu escopo de investigação fica bastante centrado no espaço do Comitê Municipal de Mudança do Clima e Ecoeconomia, instituído pelo Decreto 45.959/2005.

Furriela contribui com sua tese de doutorado ao fazer uma detalhada descrição do histórico, dos principais acontecimentos, dos atores políticos, da sociedade civil e da academia. A autora consegue trazer vários detalhes, em parte porque participou do processo enquanto coordenadora técnica do processo de formulação do anteprojeto de lei, enquanto integrante do Centro de Estudos em Sustentabilidade da EAESP-FGV. Em relação aos atores especificamente, Furriela afirma que o então Secretário do Verde e Meio Ambiente, Eduardo Jorge, desempenhou um papel chave de convencimento dos demais atores para a aceitação do Projeto de Lei, com rápida votação na Câmara Municipal e a promulgação da lei.

Já Back, ao publicar sua dissertação de mestrado em Ciência Política em 2012, traz importantes contribuições históricas e teóricas para a compreensão do processo de construção da política municipal de São Paulo. O estudo do processo de formulação dessa política está direcionado à compreensão a respeito de como a agenda climática foi incorporada na estrutura institucional dos arranjos de São Paulo. Para desenvolver essa análise, Back utiliza do conceito teórico de agenda setting, tendo como referência a produção de John Kingdon (“Agendas, alternatives and public policies”) e por objetivo identificar os elementos que explicam a formação dessa agenda de políticas públicas. Entre seus achados, Back considera que a construção progressiva da agenda climática paulistana teve início em 2003, quando o município aderiu ao ICLEI. Este representa um importante marco histórico que foi considerado no desenvolvimento da presente dissertação. 
No total foram mapeadas quatro teses de doutorado (FURRIELA, 2011; CORTESE, 2013; CAMPOS, 2014; RAMIRES, 2015) e duas dissertações de mestrado (BACK, 2012; LANDIN, 2013) que analisaram o caso da política de mudança climática na cidade de São Paulo. Esses trabalhos foram desenvolvidos a partir de diferentes abordagens e enfoques, conforme os exemplos já citados. As demais pesquisas foram desenvolvidas na área da Geografia e Saúde Pública.

Considerando o acúmulo desses trabalhos, a originalidade da presente dissertação está ancorada em alguns aspectos. O olhar a partir da Ciência Ambiental permite uma perspectiva interdisciplinar para a questão climática paulistana, levando em consideração seus aspectos políticos, sociais e ambientais. A análise de um período que incorpora quatro mandatos, iniciando em 2001 e terminando em 2016, também possibilita que a investigação inclua um percurso mais amplo, identificando elementos de diferentes contextos históricos e políticos. Por fim, a abordagem teórica utilizada permite compreender os fenômenos sociopolíticos relacionados ao contexto paulistano a partir de outros prismas, incorporando, por exemplo, componentes cognitivos e olhares específicos aos atores e os instrumentos da ação pública.

Weber (1919), visto como um dos fundadores da sociologia moderna, classifica a ciência e a política como duas vocações. Se, por um lado, a ciência fornece métodos de pensamento, a política trata de relações de poder e do exercício deste na vida social. Apesar de Weber considerar a política tão somente a ação do Estado, muito em função das circunstâncias do período em que escreveu, é possível transcender sua reflexão acerca da política para a ação pública contemporânea, com sua complexidade e multiplicidade de atores (Massardier, 2013). Resgatando essa contribuição do pensador alemão, é possível dizer que a presente dissertação é elaborada a partir da relação entre esses dois campos. A Ciência Ambiental e seus conhecimentos interdisciplinares auxilia na compreensão do fenômeno das mudanças climáticas, juntamente com o olhar preocupado com o campo das políticas públicas enquanto prática, especialmente as políticas climáticas.

Nas próximas páginas o leitor encontrará a dissertação organizada em quatro capítulos e uma conclusão. O primeiro capítulo é dedicado a esclarecimentos de ordem metodológica, de modo que fique claro o percurso trilhado pelo autor. Em seguida, o capítulo 2 apresenta um resgate teórico central, indicando quais as categorias de análise que serão aprofundadas conforme o desenvolvimento da 
dissertação. No capítulo 3 é feita uma descrição do período a ser estudado, já sendo possível observar algumas análises preliminares e identificar os principais atores, instituições e instrumentos. O capítulo 4 apresenta um conjunto de análises mais aprofundadas, considerando principalmente as descobertas identificadas a partir das entrevistas. Por fim, são feitas as considerações finais desta dissertação, seguidas pelos anexos e as referências bibliográficas.

1. Capítulo 1 - Ação pública e as perspectivas teóricas

O arcabouço teórico representa uma ferramenta importante para o aprofundamento da análise do caso selecionado. Existe um conjunto vasto de produção intelectual que poderia ser utilizado como referência na presente dissertação. Apesar de esse capítulo discriminar ao leitor qual é o referencial teórico considerado pelo autor para o desenvolvimento do trabalho, a proposta dele é fundamentar as escolhas feitas, realizar uma descrição e, igualmente, uma análise crítica sobre essas teorias.

O repertório teórico escolhido para o desenvolvimento desta dissertação tem como objetivo estabelecer "lentes" que permitam destacar determinados fatores e auxiliar na compreensão do caso a ser estudado. Durante o processo de investigação houve a preocupação de olhar os acontecimentos a partir do ferramental disponibilizado pela teoria, sabendo dos potenciais e limites de cada "lente".

Esse cuidado tem como fundamentação a crítica, presente de maneira cada vez mais contundente nos discursos dos cientistas políticos e sociais: a de que as teorias tentam, sem sucesso, colocar ordem no caos que a realidade apresenta. O positivismo exacerbado das teorias de políticas públicas desconsidera, nesse sentido, a complexidade e a dinâmica da ação pública. Conforme Massardier (2003) destaca, a política pública contemporânea é marcada pela interação intensa entre uma diversidade de atores e por um ambiente em que os atores possuem objetivos dinâmicos, que se ajustam o tempo todo, em um contexto em que o Estado não possui mais o monopólio do poder. 
Por causa disso, antes de apresentar ao leitor as teorias e suas nomenclaturas próprias, a construção deste capítulo inicia-se pela reflexão sobre as categorias de análise que serão consideradas, sem ainda enquadrá-las em qualquer referencial. Seria ingênuo afirmar que a construção desse panorama não foi influenciada pelas leituras e influências que o autor dessa dissertação sofreu ao longo do desenvolvimento do trabalho.

A pergunta de pesquisa enunciada na introdução já apresentava pistas de quais os níveis de análise que serão utilizados. O foco está direcionado para os atores e os fatores centrais que influenciaram no ritmo dos avanços da política climática na cidade de São Paulo. Organizando isso de outra maneira, os níveis de análise se apresentam da seguinte maneira, conforme apresentado na figura abaixo:

Figura 1. Categorias de análise consideradas na dissertação

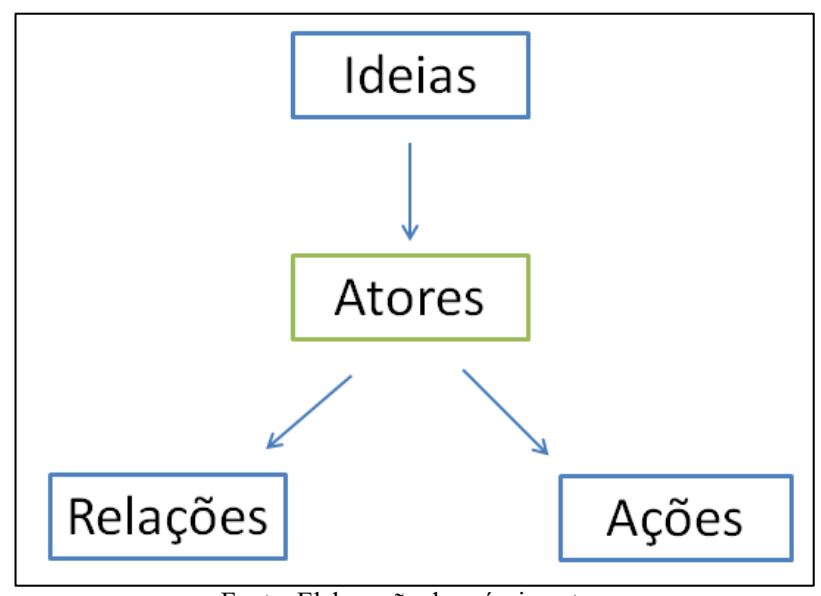

Fonte: Elaboração do próprio autor.

De maneira genérica, são esses quatro níveis de análise que interessam ao autor. As ideias representam o principal pano de fundo, que influenciam a maneira como os atores se comportam. Os atores são apresentados intencionalmente na figura acima com uma cor 
diferente, uma vez que são considerados o centro da análise por serem o fator mais dinâmico. Mais do que isso, não se trata de qualquer ator, mas daqueles capazes de transformar as ideias em políticas públicas. No último nível de análise, pode-se dizer que as subcategorias de análise que serão consideradas são as relações que os atores criam e mantêm, além das ações que eles implementam.

A categoria dos atores é destacada na figura acima por ter grande relevância na análise desenvolvida aqui. O autor da dissertação parte do pressuposto de que são os atores aqueles capazes de articular as demais categorias, dando forma e sentido às ideias, estabelecendo as diferentes relações e implementando ações. Esse pressuposto, inclusive, está refletido nas escolhas feitas do ponto de vista teórico.

Não obstante, reconhece-se a existência de produção teórica que se dedica a analisar as políticas públicas a partir do sistema (CROZIER e FRIEDBERG, 1977; FRIEDBERG, 1993). Essa perspectiva propõe uma abordagem teórica a partir da sociologia das organizações, a qual compreende que o sistema de ação social organizado - as organizações - orienta os comportamentos, circunscreve a liberdade e a capacidade dos indivíduos e, ao mesmo tempo, promove a cooperação em prol dos objetivos comuns acordados.

De todo modo, as valiosas contribuições da sociologia das organizações acima expostas não serão objeto de aprofundamento, tampouco serão consideradas na análise do caso paulistano. De maneira superficial, elas auxiliam no esclarecimento de que há uma relação intensa e de mão dupla entre os atores e o sistema e de que tanto o olhar do ator para o sistema quanto do sistema para o ator permitem compreender a complexidade da ação pública a partir de óticas significativas e, possivelmente, complementares.

Seguramente, o caso em foco nessa pesquisa apresenta uma série de informações a respeito das categorias de análise expostas acima. Em um período de 16 anos foram quatro mandatos, cinco prefeitos, seis secretários de meio ambiente e outras dezenas de secretários nas demais pastas do município de São Paulo. Foram distintos partidos e grupos políticos a frente do comando da capital paulista. Perpassando os anos de 2001 a 2016, o contexto internacional, nacional, estadual e local vivenciou uma multiplicidade de acontecimentos, com uma dinâmica socioeconômica ativa. O campo das mudanças climáticas passou por novas negociações, novas 
ideias, novos conhecimentos, novas informações e novas articulações. Por conseguinte, as categorias de análise apresentadas na figura acima sofreram muitas alterações e interações, as quais serão aprofundadas ao longo da dissertação.

Feitos os esclarecimentos e reflexões iniciais e apresentado o quadro de categorias de análise, é possível avançar para a exposição da bibliografia consultada para a composição do arcabouço teórico utilizado.

\subsection{O lugar das ideias e a abordagem cognitiva}

O papel das ideias é considerado o grande pano de fundo da análise desenvolvida nessa pesquisa, o que, de início, representa um fator importante a ser incorporado. Quando compartilhadas por um determinado grupo de pessoas, as ideias têm a capacidade de gerar mudanças empíricas significativas. Quando incorporadas pela sociedade, elas possibilitam que tais resultados sejam perenizados e institucionalizados.

Incorporar as ideias, os valores e os aspectos subjetivos na análise das políticas públicas representa, por si só, um rompimento com uma determinada abordagem que interpreta as escolhas dos atores e instituições de maneira mais funcionalista e objetiva. Essa perspectiva considera que os atores atuam de maneira puramente objetiva e racional, de modo que seus objetivos são claramente definidos. Contudo, a premissa inicial do presente trabalho considera que os atores atuam fortemente influenciados por fatores subjetivos, como as ideias e os valores, com uma racionalidade limitada pela diversidade de fatores sociais que impactam sua ação.

Esse tipo de debate entre a objetividade e a subjetividade representa uma reflexão que ganhou notoriedade pelo menos desde o início do século XX, quando o sociólogo alemão Max Weber cunhou o termo "neutralidade axiológica”. A partir desse princípio Weber reconheceu o papel dos valores e ideais, mas defendeu que a produção científica deve ser objetiva e livre de juízos de valores. Ao longo da história esse debate a respeito do papel e da influência dos valores também ocupou outros campos do conhecimento, como a Ciência Política e o Direito. 
Pierre Muller é um dos representantes da escola francesa de análise de políticas públicas que contribui para a reflexão acerca do papel das ideias na ação pública. Muller (1990) analisa as políticas agrícolas e seu desenvolvimento na França durante os anos de 1960. O autor defende o argumento de que a produção de políticas públicas é o resultado da influência tanto de fatores objetivos quanto subjetivos. Nesse sentido, Muller critica a análise weberiana, a economia política e a análise sequencial. Segundo Muller essas teorias desconsideram em suas análises elementos centrais, tais como a equidade, a justiça e as emoções.

Muller está analisando a política agrícola francesa da década de 1960, momento histórico marcado por um Estado centralizador e extremamente técnico. Esses fatores, por óbvio, influenciam a construção de todo seu arcabouço teórico. De todo modo, o cientista francês avança na tentativa de construção de um modelo que permite estabelecer as bases dessa abordagem cognitiva, as quais ele denomina como "referenciais".

Segundo o autor, os referenciais representam a tradução das representações de mundo dos atores que os utilizam, ou seja, os referenciais de um determinado ator - considerando, vale dizer, o conjunto de valores que ele traz consigo - influenciam a maneira como esse agente traduzirá suas ideias em políticas públicas. Por isso, Muller considera que o centro (cœur) de qualquer política pública está nos referenciais adotados para sua construção e implementação. Assim, Muller concebe dois grupos de referenciais, que se articulam entrei si: o global e o setorial.

O referencial global se estabelece com base em um conjunto de valores fundamentais e em normas de conduta que devem orientar a construção de determinada política pública. Nesse sentido, o referencial global é a representação mais abrangente e que irá determinar quais referenciais setoriais serão selecionados e a relevância de cada um: "O referencial global não é um consenso, mas baliza o campo intelectual no seio do qual vão se organizar os conflitos sociais” (MULLER, 2003, p. 65).

Por sua vez, o referencial setorial é a representação da função desempenhada por determinado setor na maneira como a sociedade se organiza. Como já dito, há uma relação direta entre o referencial global e o referencial setorial que orienta os atores durante suas intervenções na ação pública. 
Ambos os referenciais, ou seja, tanto as representações do mundo em relação a valores fundamentais quanto seus impactos em determinados setores são construídos e articulados entre os diferentes atores sociais pelos chamados "operadores de transação", ou então "mediadores". Os mediadores são atores com posições centrais no processo de construção e implementação de políticas públicas, que têm a capacidade de dar sentido a determinadas representações de mundo (imagens cognitivas) e de fazer com que essas ideias circulem nos diferentes espaços e organizações.

Como dito acima, o mundo observado por Muller se circunscrevia à política agrícola francesa na década de 1960 . Tendo em vista a dinâmica social atual, as diferenças na produção de políticas públicas de um lugar para outro e as idiossincrasias de cada localidade, é necessário desenvolver uma análise crítica dessa contribuição teórica.

De início, os conceitos de referencial setorial e referencial global geram uma dificuldade de enquadramento das ideias atuais, seja em um ou em outro referencial. A globalização e a aproximação do local com o global alteraram os limites existentes outrora, o que causa, portanto, um limite tênue, quiçá inexistente entre esses dois campos. Em determinados casos, uma mesma representação de mundo pode ser, ao mesmo tempo, um referencial setorial e global.

As dificuldades de enquadramento igualmente se extrapolam quando considerado o papel dos mediadores, ou operadores de transação. De fato, há de se reconhecer a inovação quanto à figura de um agente capaz de articular dois referenciais, traduzindo uma ideia para seu grupo de influência de modo que essa ideia se transforme em política pública. Entretanto, ao transpor essa figura para o mundo real e atual, uma série de limitações emerge.

Outros teóricos das políticas públicas propõem outras definições e nomenclaturas para atores centrais na produção de políticas públicas. Esse debate será feito ao longo do presente capítulo; porém, mais uma vez, o autor desta dissertação chama atenção para as dificuldades que essas definições apresentam ao propor enquadramentos de determinados atores, que precisam respeitar determinadas configurações, enquanto o mundo real é muito mais dinâmico e caótico. 
Massardier (2011) reconhece a importância da abordagem cognitiva e, ao mesmo tempo, questiona o fato de as ideias permitirem, enquanto categoria de análise e de maneira isolada, compreender o mundo atual. Esse autor afirma que os conceitos de referenciais e de operadores de transação não são mais suficientes para entender a complexidade da atualidade: “(...) as políticas públicas são o resultado de um processo complexo, pois fragmentado, e policêntrico de ação pública” (MASSARDIER, 2011, p. 81). Dessa forma, para compreender para além das ideias o que o autor chama de "nova ação pública" é necessário considerar outras duas dimensões, que são os interesses e as práticas sociais, juntamente com as estruturas sociais e organizacionais. Esse conjunto de categorias permite, segundo Massardier, compreender a produção de políticas públicas.

Em relação ao conceito de referenciais, Massardier aponta que a complexidade da modernidade implica, na maioria dos casos, a justaposição/concorrência tanto entre as diferentes representações de mundo quanto entre os espaços sociais. Essa reflexão foi feita parágrafos atrás ao se notar que as representações de mundo são muitas e que a multiplicidade de agentes produtores de políticas públicas implica uma concorrência em fazer uso, em determinados casos, das mesmas ideias, ou então, sem uma separação clara entre o que se trata de referencial setorial e o que se trata de referencial global.

Aterrissando o debate teórico no estudo de caso desta dissertação, algumas elucubrações iniciais são possíveis. De início, fica claro que a grande ideia em debate são as mudanças climáticas. O simples fato de considerar que está em curso uma mudança climática global e que os homens têm enorme responsabilidade nesse processo já posiciona o autor e a análise em um determinado espectro.

Parte do processo de construção desse campo e da circulação dessa ideia no âmbito global foi exposto na introdução desta dissertação e será explorado ao longo dos demais capítulos. O que se evidencia é que essa representação de mundo e os valores intrínsecos a esse olhar foram sendo construídos e acordados por uma diversidade de atores, fóruns e instituições. Além disso, ao passo que essa ideia foi sendo fortificada, determinadas instituições e estruturas organizacionais foram emergindo. Em termos gerais, basta retomar a construção da $U N F C C C$, os encontros anuais denominados $C O P s$, o arcabouço científico consolidado na figura do IPCC e seus relatórios anuais $(A R s)$. 
Novamente, avançando mais uma etapa no que concerne ao objeto de estudo da presente investigação científica, existe o desafio em compreender em quais condições, a partir de quais fóruns e articulações, com quais agentes e grupos políticos, foi percebido que a ideia das mudanças climáticas era importante e que, mais do que isso, deveria ser internalizada no contexto local do município de São Paulo. Para que a construção da política climática paulistana fosse possível um ator ou um grupo de atores reconheceu que o governo local tinha competência e obrigação de implementar políticas de adaptação e mitigação e, portanto, as mudanças climáticas, enquanto ideia/campo do conhecimento, tinham de ser disseminadas para uma rede mais ampla de agentes e, igualmente, traduzidas em políticas públicas. Este é parte do desafio que esta dissertação se propõe a enfrentar.

O que se pretende com essas reflexões não é desclassificar o reconhecido trabalho de qualquer produção teórica; pelo contrário, a importância de algumas abordagens é reconhecida pelo simples fato de serem utilizadas como referências. A proposta é utilizar as contribuições, mas reconhecendo as dinâmicas atuais e eventuais limitações, apontando necessidades de avanços nas teorias e possibilidades de associar diferentes visões.

A produção de Bruno Palier e Yves Surel, representantes do institucionalismo sociológico, contribui na reflexão a respeito do papel das ideias na produção de políticas públicas. Palier e Surel (2005) consideram a temporalidade de determinadas variáveis nos processos de produção de políticas públicas. Segundo os autores, as ideias, enquanto força motriz da ação pública, possuem uma temporalidade mais longa, uma vez que os valores e as maneiras de interpretar o mundo, quando incorporados por parte significativa da sociedade e dos atores-chave, são menos suscetíveis a mudanças.

Sabatier (1987) também reconheceu essa centralidade, inclusive ao defender o argumento de que as ideias, ou seja, as crenças compartilhadas, representam a principal "cola" do processo de formação de políticas públicas. Dessa maneira, destaca-se a importância de considerar os valores das mudanças climáticas no contexto da política paulistana, de modo a investigar se essa ideia foi incorporada, a profundidade desse processo e os grupos envolvidos, compreendendo, assim, os eventuais avanços e retrocessos nessa agenda. Ao decorrer da análise e do debate da política climática paulistana entre os mandatos de 2001 e 2016, ficará clara importância dessa categoria de análise para sua institucionalidade e perenidade. 
Se as políticas públicas são "ideias em ação", conforme Muller (1990) afirmou, essa variável representa o ponto de partida da presente investigação. A seguir são apresentadas demais dimensões que, aos olhos desse autor, merecem ser consideradas, considerando, eventualmente, seus limites e contribuições, incorporadas na análise da política climática do município de São Paulo.

1.2. Os múltiplos atores nas políticas públicas: diferentes nomes para o mesmo fenômeno?

Os atores são considerados nesta dissertação uma categoria de análise central para compreender as dinâmicas da ação pública. A relação ativa entre os atores e as ideias é determinante para compreender o desenvolvimento das políticas públicas.

Essa escolha metodológica induz ao desenvolvimento de uma análise "ator-centrada" e não sistema-centrada. Entretanto, isso não significa desconsiderar a influência do sistema na construção e no desenvolvimento da política climática paulistana.

A dinâmica e complexidade social implicam na existência de uma multiplicidade de atores no campo da política pública. As teorias observam esses fenômenos e propõem uma forma de organizá-los, com nomenclaturas e definições próprias, de modo que um mesmo ator, em um mesmo período e uma mesma circunstância, pode ser classificado de diferentes maneiras, a depender do referencial adotado. A presente seção propõe apresentar, de forma crítica, ao leitor algumas das construções teórico-conceituais acerca dos atores que influenciam a construção de políticas públicas.

\subsubsection{Empreendedores - John Kingdon}

Kingdon é um representante do espectro clássico de compreensão e análise das políticas públicas e, portanto, se insere em um contexto ainda fortemente estadocêntrico, com características pragmatistas e racionalistas.

A contribuição de Kingdon é considerada um marco teórico no âmbito da Ciência Política, sendo encontrada em muitas produções científicas. Entre elas, destaca-se o trabalho de Back (2012), no qual o pesquisador também investiga o caso da política de 
mudanças climáticas do município de São Paulo. Na ocasião, o pesquisador de Ciência Política da Universidade de São Carlos incorpora ao centro de sua reflexão o conceito de agenda-setting do teórico estadunidense, sem grandes considerações a respeito da figura do empreendedor de políticas públicas.

Em sua obra "Agendas, Alternatives, and Public Policies" (1984), Kingdon deixa claro logo de início que o foco de sua atenção está em compreender como os problemas são reconhecidos e definidos no campo político. O autor resgata o conceito de ciclo de políticas públicas e suas etapas de definição de agenda, de construção de alternativas, de processos decisórios e de implementação. Considerando esse ciclo, Kingdon explicita que o centro de sua pesquisa considera apenas as duas primeiras etapas. Enquanto a primeira etapa, agenda setting, é, geralmente, tratada pelas autoridades, a segunda etapa de estudo das alternativas é conduzida normalmente pelos chamados experts.

Em relação ao conceito de "agenda", que inclusive inicia o próprio título da obra, Kingdon esclarece que se trata da lista dos assuntos e problemas que os "government officals and people outside of government closely associated with those officials" estão seriamente prestando atenção. Para construir e aplicar o arcabouço teórico construído, o autor estadunidense consultou e analisou em sua obra as políticas públicas de saúde e transportes dos EUA.

Segundo o autor, existem dois fatores que impactam a definição da agenda e a construção de alternativas. O primeiro fator são os participantes, responsáveis por levar os assuntos aos líderes do governo, difundir as ideias e influenciar as mudanças políticas. O segundo fator envolve os processos de reconhecimento de um problema e de construção das propostas e os eventos políticos como as eleições.

No caso da presente dissertação, o foco das atenções se concentra no primeiro fator, os participantes, especialmente em um tipo de participante, que Kingdon define como empreendedores de políticas públicas (policy entrepreneurs). Esses atores investem seus recursos, como tempo, energia, reputação e dinheiro, para defender e promover suas propostas e ideias, tentando fazer com que pessoas 
importantes as considerem relevantes e aproximando problemas, soluções e oportunidades políticas. Os empreendedores podem ser pessoas que estão dentro ou fora da estrutura do Estado.

Entre as qualidades de um empreendedor o autor destaca sua habilidade para defender sua ideiasuas conexões políticas e sua capacidade de negociação, além da persistência e da agilidade em aproveitar as janelas de oportunidade. Mais especificamente, Kingdon esclarece que os empreendedores têm a habilidade de aproximar três esferas: os problemas, considerando os eventos chamariz e a divulgação de indicadores; a política e seus acontecimentos mais relevantes, como as eleições; e os participantes, sejam do quadro oficial do governo ou não, que tenham a capacidade de trazer a atenção pública para determinado problema.

As razões que motivam esse tipo de comportamento por parte dos empreendedores podem ser variadas e, nesse sentido, o cientista político clássico ressalta algumas possibilidades. Os empreendedores podem ser motivados a defender uma ideia, quando já possuem soluções prontas para problemas que emergem, por causa de interesses pessoais ou interesses de um determinado grupo (lobby) para colherem benefícios eleitorais, por causa das ideias estarem de acordo com os valores que defendem e acreditam, ou, por fim, por simplesmente gostarem do jogo.

Kingdon faz um alerta final: "Finally, we should not paint these entrepreneurs as superhumanly clever. It could be that they are - that they have excellent antennae, read the windows extremely well, and move at the right moments" (Kingdom, 1984, p. 192). Ainda que sejam participantes centrais no processo de definição da agenda e de construção de alternativas, o autor estadunidense entende que resultados positivos são efetivamente alcançados a partir do trabalho de um conjunto mais amplo de pessoas

Essa seção pretendeu, dessa maneira, fazer uma leitura crítica da contribuição teórica de Kingdon, identificando os elementos que podem ser utilizados na análise do caso selecionado e, ao mesmo tempo, notando determinadas limitações.

A primeira observação a ser feita é o "lugar do mundo" a partir do qual o autor analisa as políticas. O olhar clássico encontra barreiras na complexidade do mundo contemporâneo, marcado por uma conjunção policêntrica de atores e de formas de atuação, em que o Estado não detém mais o monopólio da produção de políticas públicas. 
Em segundo lugar, é importante ter em mente que, quando Kingdon aborda a capacidade de determinados atores difundirem ideias, o autor está considerando questões bastante concretas. Não se trata de um elemento cognitivo subjetivo, uma visão de mundo, mas uma proposta empírica. Nesse sentido, nota-se que Kingdon desconsidera em grande parte a primeira variável que o autor da presente dissertação determinou como grande pano de fundo da análise da ação pública: as ideias enquanto valores e interpretações de mundo, ou seja, há um descompasso significativo que não pode ser ignorado.

Em relação aos policy entrepreneurs, verifica-se, mais uma vez, que a produção teórica avança na tentativa de elencar determinadas características sem as quais determinado ator não se enquadraria no perfil criado. Vale dizer, segundo as determinações de Kingdon, que um empreendedor de política pública tem a capacidade de transformar uma ideia em política a partir da aproximação entre atores-chave, eventos políticos e determinados problemas. Considerando esse emaranhado de definições, a dúvida que emerge ao observar a dinâmica da realidade é: caso uma das condições não seja atendida, não se pode então considerar determinado ator enquanto um empreendedor? Assim, é preciso reconhecer que existem outros elementos a serem incorporados na observação dos fatos concretos, como os aspectos cognitivos subjetivos, que influenciam os comportamentos, como já dito.

De todo modo, Kingdon indica qualidades relevantes para auxiliar na identificação de atores-chave, as quais serão levadas em consideração aqui. Entretanto, a análise da ação pública que esta dissertação se propõe a fazer não se limitará a essas características.

\subsubsection{Brokers - Paul A. Sabatier}

A produção teórica de Sabatier é reconhecida, sobretudo, a partir do conceito de advocacy coalition framework, proposto pelo autor em sua obra "An Advocacy Coalition Framework of Policy Change and the Role of Policy-Oriented Learning Therein" (1988). Nela ele argumenta que, no terreno das políticas públicas, existe uma composição de alianças e aproximações de determinados atores, classificada pelo autor como coalizões, o que contribui para o avanço ou não de determinadas agendas. 
Essas coalizões têm a função de influenciar as tomadas de decisões. Sua composição se estabelece pela presença de agentes com mandato ou sem mandato, mas que compartilham entre si um conjunto específico de "sistema de crenças" (belief system). Esse conjunto de crenças diz respeito tanto a valores e ideais de ordem cognitiva e mais subjetiva quanto à percepção de um problema social. O diferencial desses grupos, chamados de advocacy coalitions, é sua capacidade de coordenação e de influência nos processos de tomada de decisão.

O esquema abaixo tenta representar o raciocínio de Sabatier ao identificar dois elementos centrais para a aproximação de atores na formação de uma coalizão: um conjunto de ideias e uma proposta objetiva para resolver determinado problema. A primeira observação a ser feita nesse sentido é reconhecer que o teórico estadunidense leva em conta uma relativa centralidade dos aspectos cognitivos, como os valores e as ideias dos agentes, sendo, portanto, uma variável que influencia na análise da produção de políticas públicas. Quando comparada à produção de Kingdon, esta é uma diferença significativa. Entretanto, essa centralidade é "relativa", uma vez que os demais aspectos objetivos ganham maior relevância na análise proposta por Sabatier - por isso a representação gráfica abaixo, com diferença entre os tamanhos do box.

Nesse sentido, a figura do broker atua exatamente na relação entre as diferentes coalizões. Os denominados policy brokers são atores com a capacidade de inserção e relacionamento com as diferentes coalizões. São os brokers que minimizam os conflitos entre os grupos diferentes, facilitam seu relacionamento, conseguem identificar as sinergias e uma agenda mínima entre as partes e, por fim, produzem "workable compromises" entre as coalizões, de modo a gerar um impacto positivo no tomador de decisões. 
Figura 2. Policy broker, segundo Sabatier

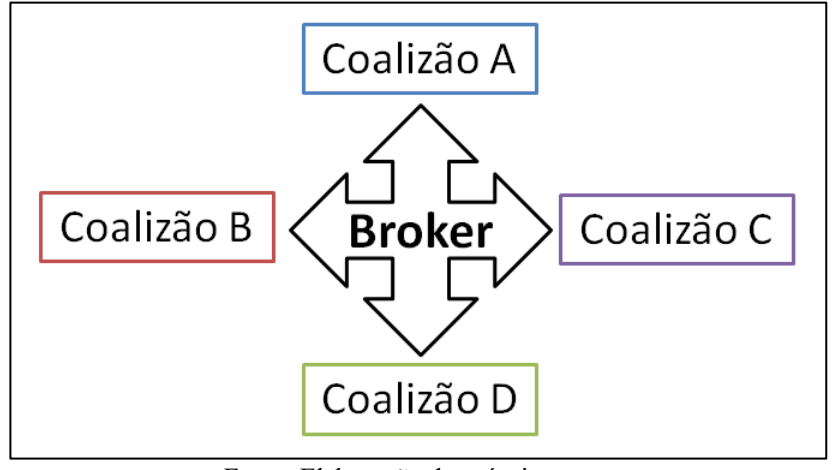

Fonte: Elaboração do próprio autor

Em poucas palavras, o broker é um mediador entre as diferentes coalizões. A depender da situação, uma mesma figura pode desenvolver a função de integrante de uma coalizão, de tomador da decisão, ou então, de broker.

Considerando essa capacidade de transação entre os grupos, seja enquanto integrante, seja apenas influenciador, a construção conceitual proposta por Sabatier enseja uma compreensão de que há um baixo custo de entrada e saída das coalizões, seja ele político ou de outra ordem. Caso esse custo fosse mais elevado, eventualmente a figura do broker seria outra.

De maneira geral, a leitura da produção teórica de Sabatier leva a entender que, ainda que os aspectos cognitivos, como os valores e princípios, sejam incorporados, seu peso é relativamente pequeno quando comparado aos demais aspectos. De certa maneira, há, inclusive, certa contradição entre a construção teórica das coalizões e dos brokers e o argumento defendido pelo mesmo autor de que as ideias são a "cola" da produção de políticas públicas. As advocacy coalitions aparentam, então, serem estruturas muito frágeis, uma vez que são concebidas sob uma ótica utilitarista, em que, quando o objetivo empírico é alcançado, sua razão de ser se esvai. 
De todo modo, as contribuições de Sabatier são importantes para avançar a compreensão da ação pública e serão resgatadas quando necessário ao longo da construção da presente dissertação. Seguramente, observar os atores, sobretudo aqueles que têm a capacidade de circular entre diferentes grupos, representa um ponto de atenção para entender a produção da política climática paulistana.

\subsubsection{Mediadores - Pierre Muller}

Para compreender as contribuições de Pierre Muller em sua obra "Les politiques publiques" (1990), é preciso levar em conta que sua atenção está voltada à política agrícola francesa da década de 1960. É sobre esse contexto, bem diferente do atual, diga-se de passagem, que o autor vai aprofundar sua análise para conceber os alicerces da abordagem cognitiva.

A produção científica do autor estabelece uma diferença significativa em relação às obras clássicas uma vez que coloca no centro da análise das políticas públicas a cognição. Nesse sentido, a abordagem cognitiva proposta por Muller rompe com as "raisons d'agir" clássicas ao entender que os valores compartilhados pelos atores auxiliam na coordenação do processo de produção de políticas públicas e funciona, portanto, como uma bússola para orientar a ação pública.

Há dois conceitos centrais na construção dessa proposta teórica:

O primeiro trata dos "referenciais", que são representações de mundo e os elementos subjetivos que orientam a atividade humana, desde valores como equidade e igualdade, até princípios como a defesa do meio ambiente. Essa abordagem proposta por Muller, a partir da qual um determinado conjunto de valores dão sentido a um programa de ação, rompe com as análises clássicas que consideram apenas os aspectos da burocracia, do mercado e da técnica na produção de políticas públicas. Assim, existem tanto os referenciais globais, que consideram elementos mais abrangentes, quanto os referenciais setoriais, direcionados a determinada pauta da agenda pública. É, portanto, o referencial que produz o sentido cognitivo compartilhado que permite construir a coerência na ação pública. 
O segundo conceito é a figura do mediador de políticas públicas. É o mediador que constrói o significado de determinado referencial, articula os referenciais global e setorial para dar-lhes sentido e, a partir disso, articula essas ideias com seus pares e com demais setores. Esse ator, considerado por Muller como de grande relevância, tem uma capacidade intelectual diferenciada, uma vez que consegue traduzir os valores mais subjetivos em ideias mais objetivas e articulá-las com demais atores-chave na política. Ao mesmo tempo, o mediador tem a capacidade de, a partir dessa articulação, influenciar os demais atores sociopolíticos para que essas ideias se tornem políticas públicas de fato:

"Le rôle du médiateur est à la fois intelectuel et politique: porter le référentiel, l'ordonner, le 'dire', et en même temps, lutter politiquement dans son groupe pour le diriger. De plus, au-delà de leur propre groupe, ces médiateurs assurent la médiation avec les autres secteurs" (Massardier, 2003, p. 160).

Segundo Muller (1990), a figura do mediador exerce uma dupla função, uma de ordem intelectual e outra de ordem política, sendo capaz de transformar uma ideia, um conjunto de valores, em políticas públicas objetivas. Em outras palavras, o mediador tem a habilidade de, a partir de um determinado valor, articulá-lo com um conjunto de atores-chave e produzir uma coerência social de modo que políticas públicas surjam a partir daí.

O mesmo elemento que permite classificar a produção de Muller como inovadora à época, ao quebrar o paradigma das análises clássicas, também dá pistas de sua relativa limitação para compreender a complexidade dos processos de produção de políticas públicas na contemporaneidade. Se, por um lado, a relevante contribuição de Muller incorpora o campo da cognição, variável que era praticamente desconsiderada pelos demais teóricos da área; por outro lado, o autor, ao centrar suas atenções nas ideias e nos valores, acaba por negligenciar demais aspectos que notadamente se fazem presentes e necessários para analisar as políticas públicas.

Em função disso, Massardier (2003; 2011) constrói uma visão crítica da produção de Muller e identifica alguns elementos desconsiderados em sua produção. Massardier inicia sua análise observando que o mundo contemporâneo é marcado por uma descentralização do poder, em que o Estado tem de dividir a produção de políticas públicas com demais atores e, por consequência, os interesses em jogo são diversos e difusos. Esse contexto implica uma situação em que a perspectiva cognitiva não disponibiliza o 
ferramental necessário para compreender a realidade. Assim, a complexidade da modernidade exige que outros componentes sejam aliados à perspectiva cognitiva, como os interesse, as práticas sociais e as estruturas sociais e organizacionais.

Nota-se, então, que o mundo contemporâneo e suas dinâmicas demonstra uma complexidade que é incapaz de ser analisada e explicada simplesmente pela ótica da abordagem cognitiva. Entretanto, é de se considerar que a produção de Muller tem relação direta com a primeira categoria de análise proposta pelo autor da presente dissertação, em que o campo cognitivo é o grande pano de fundo da análise da política climática paulistana. Assim sendo, o conceito de mediador, guardadas suas limitações, ganha significativa relevância ao decorrer das páginas desta pesquisa.

A partir da apresentação desenvolvida acima é possível compreender que as teorias do campo das políticas públicas permitem observar e analisar os atores que participam de seus processos de diversas perspectivas. Cada autor e sua respectiva abordagem teórica contribui de maneira significativa ao propor um determinado ferramental com potencial de traduzir a ação pública.

Considerando especificamente a categoria de análise selecionada nessa seção, os atores, as três definições apresentadas ao leitor - empreendedores, brokers e mediadores - contribuem para a leitura da realidade. Entretanto, se o analista de políticas públicas se limitar às definições teóricas, terá imensa dificuldade de "enquadrar" um determinado ator da vida real. Cada ator se comporta de uma determinada forma a depender da arena ou do fórum em que se encontra, do público para quem fala, do contexto político, do tema e de outras características. Por causa dessa hibridez, surge uma dificuldade quase que insuperável de enquadrar um determinado ator segundo as características delimitadas por cada um dos teóricos, ou seja, há uma barreira na aproximação entre teoria e realidade.

A figura do mediador pode contribuir para identificar atores-chave na política climática paulistana, compreendendo a teia de relações formatada e os instrumentos implementados.

A princípio, é possível identificar dois grupos distintos de atores que tiveram relativo protagonismo na agenda climática do município de São Paulo ao longo do período analisado. De 2001 a 2016 passaram pela gestão municipal quatro prefeitos, de espectros políticos distintos. Marta Suplicy (PT), José Serra (PSDB), Gilberto Kassab (PFL/DEMPSD) e Fernando Haddad (PT). Nesse mesmo 
recorte temporal, estiveram à frente da Secretaria do Verde e Meio Ambiente seis diferentes secretários, a saber: Stela Goldenstein, Adriano Diogo, Eduardo Jorge, Ricardo Teixeira, Wanderley do Nascimento e José Tadeu Candelária. São essas pessoas que ganham maior destaque nas produções, na literatura e nas reportagens sobre a política climática do município de São Paulo. Entretanto, uma investigação mais aprofundada permite compreender como outros atores participaram desse processo e, por isso, é importante ter mais clareza sobre a teia de relações que existia anteriormente e que foi sendo criada e alimentada durante esse período. Estabelecer essa teia de relações permite entender quem ocupava posição de liderança, quem exercia determinadas funções e como a ideia das mudanças climáticas circulava nesse ambiente.

\subsection{As relações e as redes de políticas públicas}

A ideia de redes de políticas públicas representa um importante elemento teórico para compreender a ação pública contemporânea. Por essa razão, as relações representam o terceiro nível de análise que a presente dissertação se propõe a incorporar na análise da política climática.

Existem diferentes formas de configuração das relações, a depender do perfil de seus integrantes, do contexto e de seu propósito de existência. A produção teórica organiza e cria definições a partir do tipo de relação estabelecida, o que se convencionou chamar de redes de políticas públicas. Nesse sentido, essa seção tem como objetivo esclarecer o que é uma rede e quais as estruturas que sua conformação pode tomar no âmbito das políticas públicas. Essas definições serão retomadas ao longo da dissertação, além de representar um elemento central para as análises conclusivas da política climática paulistana.

A produção de Gilles Massardier, mais especificamente sua obra "Politiques et action publique" (2013), será a referência para a exposição desse aspecto teórico. O cientista francês dedica o capítulo 5 de sua obra para detalhar as diferentes abordagens da perspectiva da ação pública. 
Dependendo das características de cada grupo, seja em termos de poder, seja em termos da relação entre seus membros e os instrumentos utilizados (dispositifs tangibles), a rede se organiza de uma determinada forma, recebendo, portanto, uma nomenclatura específica. A princípio, são descritos três tipos de redes: as redes de projetos, as comunidades de política pública e as comunidades epistêmicas.

As redes de projetos ou redes temáticas apresentam um objetivo específico muito preciso, o que faz com que a razão de existir desse grupo seja limitada até o momento em que esse objetivo é alcançado, tendo sua continuidade menos prolongada se comparada às demais. Esse tipo de rede se diferencia das outras por ter um custo de entrada baixo, com um processo de entrada menos severo e suas fronteiras mais permeáveis para a saída e entrada de membros.

Por sua vez, a característica central da comunidade de política pública é que os membros que a integram partilham entre si um conjunto de valores, uma perspectiva cognitiva, ou uma raison pour agir em relação à determinada política pública. Por causa disso, esse tipo de rede é mais unificado, consolidado e fechado, o que faz com que o custo de entrada seja alto, em termos de investimento afetivo, de tempo e de dispêndio de recursos. Mais do que um projeto ou um problema específico, o que une seus integrantes é, de fato, uma política pública.

Por fim, existem as comunidades epistêmicas. Essa rede também tem como principal característica o compartilhamento entre seus membros de determinadas ideias e valores. Não obstante, o que diferencia as comunidades epistêmicas das demais é que seus integrantes são especialistas em determinado assunto. Outro elemento que une essa rede é o fato de que os especialistas que integram determinada rede compreendem determinado fenômeno, do ponto de vista de suas causas e efeitos, de maneira similar.

Comparando especificamente a comunidade de política pública e a comunidade epistêmica, que são redes mais fechadas e, portanto, com um custo maior de entrada de um novo integrante, não fica claro se existe ou não, se é necessário ou não, a existência de uma liderança. Essa dúvida se reflete na representação ilustrativa exibida acima, dado que, no esquema apresentado, a comunidade de 
política pública tem um líder que se relaciona diretamente com todos integrantes do grupo, enquanto na comunidade epistêmica não há uma figura central que una todos seus membros.

Ainda que essas três definições de redes auxiliem a compreensão da realidade, o leitor pode estar se perguntando se apenas elas são suficientes, vide a complexidade da vida real e as múltiplas possibilidades de organização. Essas definições lançam um olhar para as configurações intra-redes, mas é importante levar igualmente em consideração as relações inter-redes, algo que é uma realidade constante no contexto político. Outra possibilidade que também merece atenção é a relação das redes de políticas públicas com determinadas articulações nacionais e internacionais. O caso da política climática paulistana fornece um exemplo interessante, a saber: a relação das redes de políticas públicas do município com as articulações internacionais do ICLEI (não governamental) e do C40 (governamental).

A ideia de rede de ação pública contribui, portanto, para a compreensão das diferentes formas de organização social em um contexto em que os atores sociais e o Estado estão fragmentados. Cada conformação de rede, a depender de seu propósito e suas lideranças, tem um determinado custo de entrada e de saída, sendo esta outra característica a ser observada pelo analista de política pública.

Ao longo dos capítulos desta dissertação será possível identificar a teia de relações entre os atores e como os diferentes grupos agem, com estratégias e objetivos diferentes. Será igualmente investigado o papel dos atores, de modo a identificar aqueles que exercem uma liderança dentro desses grupos, representando, assim, a força convergente entre os diferentes participantes da rede, bem como as figuras com capacidade de interlocução entre redes distintas. Em relação à liderança será interessante notar como ela se estabelece, se é uma liderança carismática, se é uma liderança que tem o domínio do problema, ou então, se é uma liderança política. Especificamente nesse ponto será importante resgatar os conceitos de mediador e broker, apresentados na seção anterior.

Esquemas ilustrativos das redes configuradas no âmbito da política climática paulistana serão apresentados no decorrer da dissertação, de modo a avançar na tentativa de identificar as redes existentes, seus integrantes e as eventuais relações entre as redes. 


\subsection{As ações e os instrumentos da ação pública}

Observar os instrumentos da ação pública é uma oportunidade de compreender como as ideias dos atores se materializam em ações. Dessa maneira, os instrumentos, de maneira similar às redes, permitem aproximar a primeira e segunda categoria de análise proposta na abordagem teórica desta dissertação, considerando a maneira como as ideias e valores de determinados atores são cristalizados em políticas públicas de fato.

Segundo Lascoumes e Le Galès (2005), é possível identificar ao menos cinco tipos de instrumentos: o legislativo e normativo; o econômico e fiscal; o convencional e incentivador; o informativo e comunicacional; e as normas e padrão. A depender da perspectiva teórica utilizada, os instrumentos são definidos e compreendidos de maneira distinta. Essa seção pretende, então, explorar diferentes abordagens que trabalham com o conceito de instrumentos.

Entre as produções consideradas para essa categoria de análise encontram-se Christopher Hood, representante da escola inglesa, e Pierre Lascoumes, Patrick Le Galès e Louis Simard, representando a escola francesa de políticas públicas.

Christopher Hood é um renomado cientista social inglês que, a partir de sua obra "Tools of Government", de 1983, começou a construção de um movimento teórico que compreende a produção de políticas públicas a partir dos instrumentos utilizados pelos atores. Sua análise se estabeleceu por meio da categorização dos instrumentos da ação pública entre aqueles utilizados para reunir informações e aqueles utilizados para influenciar comportamentos, ainda que em determinados momentos eles se sobreponham um ao outro. Em seguida, Hood identificou que as utilizações de instrumentos de ambas as categorias se estabeleciam a partir de quatro recursos sociais "nodality" (capacidade do governo de articular diferentes redes de informações), "authority" (poder legal e legitimidade), "treasure" (ativos e recursos) e "organization" (capacidade de ação direta em setores como polícia, forças armadas e burocracia). 
Figura 3. Objetivos dos instrumentos, segundo Hood

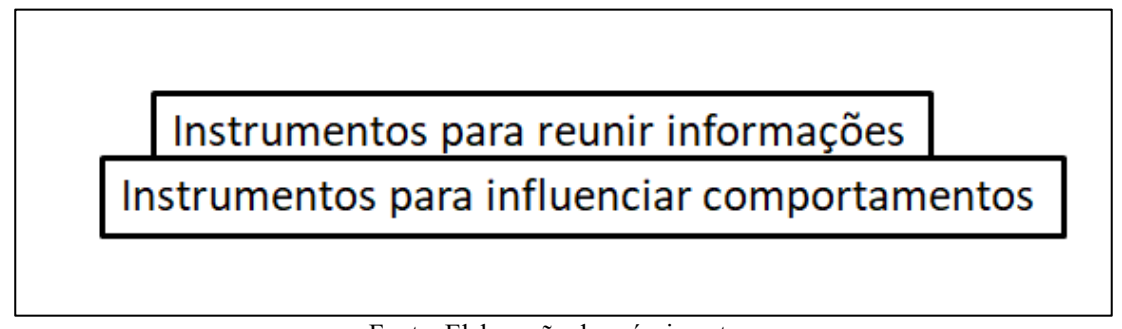

Fonte: Elaboração do próprio autor.

Mais de vinte anos após a publicação da obra inicial, Hood se questionou sobre a atualidade de suas contribuições teóricas de outrora, organizando essa reflexão nas obras "Intellectual Obsolescence and Intellectual Makeovers: Reflections on the Tools of Government after Two Decades" e "The Tools of Government in the Digital Age", ambas publicadas em 2007. O autor parte da constatação de que o mundo moderno passou por uma mudança significativa, baseada em três pilares que alteram a maneira como as políticas públicas são desenvolvidas e o próprio funcionamento dos aparatos governamentais. Inicialmente, o primeiro pilar se estabelece em termos ideológicos, sobretudo com a ascensão de uma "nova direita". Em seguida, existem as mudanças em termos tecnológicos, que alteraram a dinâmica e as possibilidades de trabalho. Por fim, existem os interesses, uma vez que parte do trabalho de administrações públicas foi "terceirizado", como a indústria militar-industrial.

Lascoumes e Le Galès são, por sua vez, representantes da chamada escola da sociologia política francesa. A partir da obra “Gouverner par les instruments”, publicada em 2005, é possível avançar na compreensão sobre o que são os instrumentos da ação pública e qual a relevância em analisar as políticas públicas a partir dessa perspectiva. De início, os autores definem a ação pública como espaço sociopolítico construído por instrumentos, finalidades e projetos de cada ator. Os instrumentos que atuam nesse espaço são compreendidos como dispositivos técnicos e sociais que organizam as relações entre governantes e governados. Cada instrumento é concebido e selecionado a partir dos valores e da visão de mundo dos atores que o utilizam. 
Lascoumes e Le Galès (2005) compartilham, nesse sentido, do entendimento de que os instrumentos da ação pública são instituições socialmente construídas, além de influenciar os comportamentos, gerar constrangimentos e privilegiar determinados interesses. Todo instrumento é composto por três elementos que o constituem como "dispositivo técnico e social": os valores fundamentais que o conceberam, ou seja, características de ordem cognitiva; uma representação sobre formas de organização; e o seu propósito técnico declarado.

Figura 4. Objetivos dos instrumentos, segundo Lascoumes e Le Galès

Instrumentos para influenciar comportamentos

Instrumentos para gerar constrangimento

Instrumentos para privilegiar interesses

Fonte: Elaboração do próprio autor. 
Figura 5. Componentes dos instrumentos da ação pública, segundo Lascoumes e Le Galès

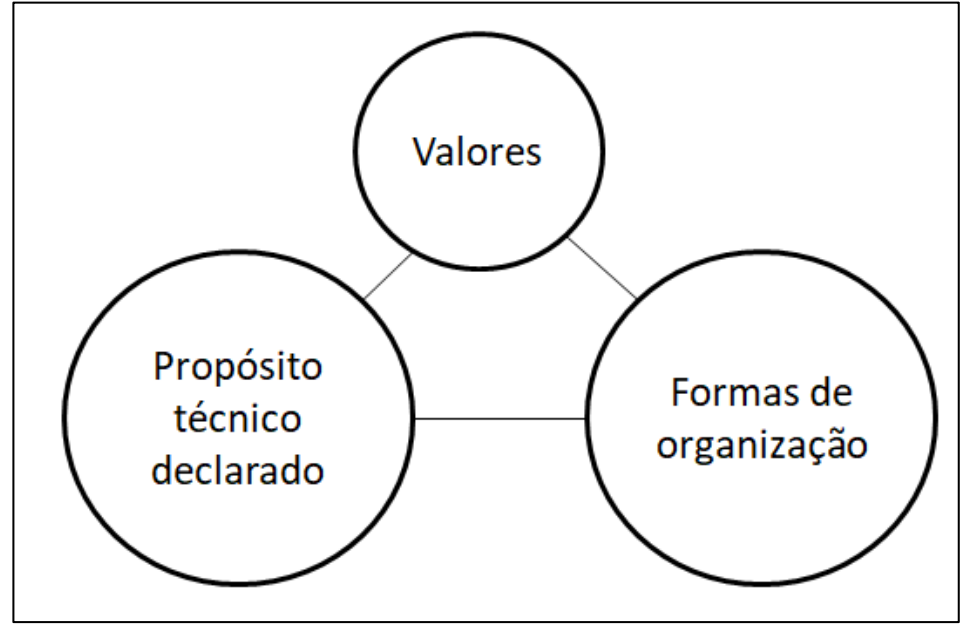

Fonte: Elaboração do próprio autor.

A definição dada por Lascoumes e Le Galès e a própria identificação desses três componentes permitem compreender as diferenças entre a abordagem dos autores franceses e a dos demais teóricos clássicos, tal como Hood. Lascoumes e Le Galès defendem a ideia de que os instrumentos não podem ser investigados e analisados considerando-os somente como "meios" para determinada finalidade. Há de se considerar as características de ordem cognitiva, os objetivos não declarados e os impactos que geram na relação Estado-sociedade e na própria estrutura do Estado. Enquanto abordagem metodológica de análise de políticas públicas, compreender os instrumentos da ação pública como "dispositivos técnicos e sociais" permite, portanto, complementar as teorias clássicas, ao incorporar a historicidade dos instrumentos, suas características cognitivas e normativas, a rede de atores envolvidos e os efeitos que produzem. 
Lascoumes e Le Galès insistem no entendimento de que a concepção e a escolha de determinados instrumentos não são um processo neutro, tampouco simplesmente técnico: "Um instrumento não é jamais redutível a uma racionalidade técnica pura" (LASCOUMES E LE GALÈS, 2005, p. 22). Uma vez que instrumentos são instituições sociais, eles representam os interesses e preferências daqueles que os conceberam. Além disso, os autores entendem que a análise das políticas públicas a partir dos instrumentos auxilia na identificação de mudanças na estrutura e no comportamento do Estado.

“(...) les instruments qui permettent à l'État d'exercer son contrôle, de contraindre, de modifier les comportements. Le choix
d'un instrument par des représentants de l'État produit sur le moyen terme des effets structurants et contraignants qui
réaffirment la capacité de l'État à imposer les règles du jeu (...) Ces instruments, qui vont dans le sens de ce que les auteurs
anglo-saxons appellent 'regulatory state', à savoir un mélange de régulations et de réglementations, se révèlent de puissants
instruments de contrainte qui modifient en profondeurs le comportement des acteurs.” (LASCOUMES E LE GALĖS, 2005, p.
368).

Pierre Lascoumes e Louis Simard (2011), na publicação "L'action publique au prismes de ses instruments", auxiliam no entendimento de como se dá o processo de escolha dos instrumentos. Segundo esses autores, existem múltiplas variáveis, de diferentes naturezas, que permitem avançar nessa explicação. Em uma escala macro, normalmente são considerados a influência de organizações e os acordos internacionais, além do papel da circulação das ideias. No nível médio, destacam-se o papel das instituições e as práticas históricas. Por fim, incorporando aspectos mais micro, são levadas em consideração as preferências e os interesses pessoais como fator preponderante para a escolha de determinado instrumento. 
Figura 6. Variáveis que influenciam a escolha dos instrumentos (Lascoumes e Simard)

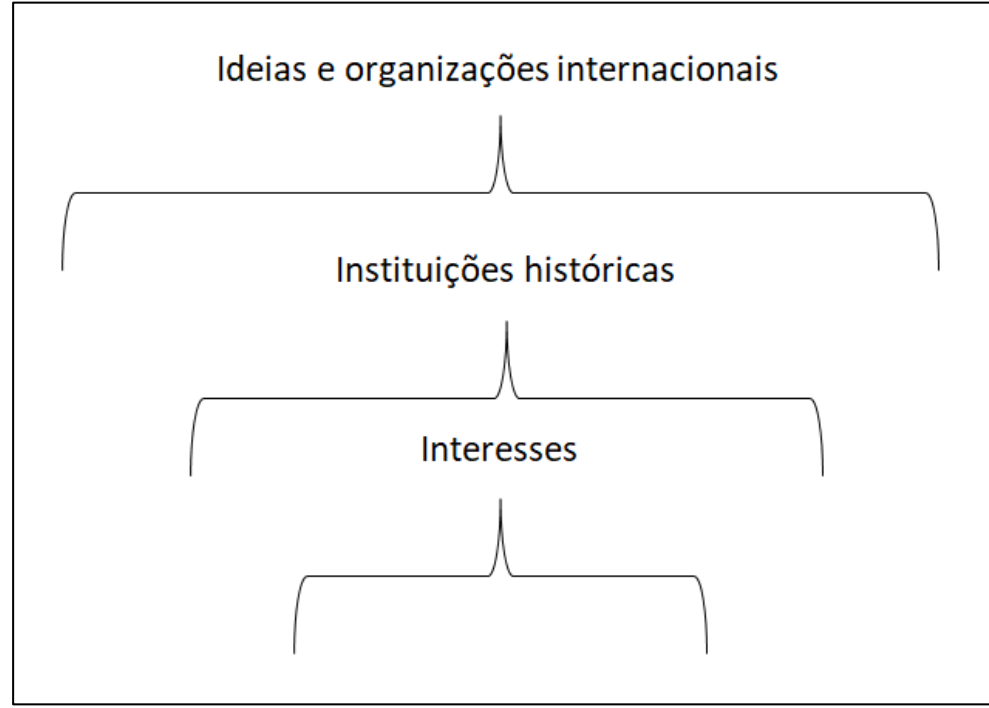

Fonte: Elaboração do próprio autor.

Ampliando as contribuições teóricas da escola francesa a respeito dos instrumentos da ação pública, os instrumentos geram efeitos não somente em seus alvos declarados, conforme já dito: “Os instrumentos da ação pública não são inertes, simplesmente disponíveis para mobilizações sociopolíticas, eles detêm uma força de ação própria” (LASCOUMES E SIMARD, 2011, p. 34). Assim o instrumento cria efeitos de inércia, tendo que demonstrar-se resistente a pressões externas provindas de interesses distintos daquele que ele representa. Em segundo lugar, o instrumento produz uma representação dos valores que ele representa, carregando consigo, portanto, uma série de características cognitivas que auxiliam a compreender suas "razões de agir". Por fim, o instrumento induz ao desenvolvimento de debates sobre determinada situação, uma vez que ele hierarquiza e propõe intervenções nela. 
A abordagem a partir dos instrumentos possibilita, desse modo, identificar como a própria estrutura do Estado se estabelece e como as relações entre governantes e governados se desenvolve. Nesse sentido, os instrumentos servirão como ferramenta importante para compreender a política climática paulistana.

Em relação à estrutura do Estado, os instrumentos colaborarão com a compreensão do motivo e do modo como as mudanças climáticas entraram na agenda e, inclusive, o período em que estas de fato se mantiveram no centro da política municipal. Do ponto de vista legal, sem dúvidas a Lei Municipal n. 14.933/2009 cumpriu um papel fundamental na construção e institucionalização da política climática na cidade, ao instituir a Política Municipal de Mudança do Clima. Entretanto, essa legislação representou apenas um acontecimento (importante), inserido em um percurso mais longo, repleto de avanços e desafios.

O próprio Eduardo Jorge, Secretário do Verde e Meio Ambiente na época da construção do projeto de lei e da aprovação deste pela Câmara Municipal, destaca esse argumento no documento "Diretrizes para o plano de ação da cidade de São Paulo para mitigação e adaptação às mudanças climáticas”, publicado em maio de 2011. “O caminho até a 'Lei do Clima' foi construído gradativamente, com iniciativas palpáveis (...)” (p. 10). Entre essas ações, como o próprio então Secretário indica nesse mesmo documento, está, por exemplo, o inventário de emissões, publicado em 2005. Assim como ele, outros instrumentos também alteraram a estrutura do governo municipal paulistano, de modo que as mudanças climáticas fossem incorporadas.

Nos próximos capítulos, dedicados a entrar com maior profundidade nos acontecimentos da vida política paulistana de 2001 a 2016, os instrumentos da ação pública em mudanças climáticas serão identificados e analisados.

\subsection{Considerações finais do capítulo}

As páginas acima se dedicaram em definir e esclarecer ao leitor as categorias de análise que serão observadas durante a construção da dissertação. Assim, as ideias, os atores, as relações e as ações representam as categorias de análise. Transportando as teorias de políticas públicas ao campo, essas categorias ganham nomenclaturas e definições próprias, a depender do autor que trabalha 
com as elas e, automaticamente, das referências e influências que o autor traz consigo. Do ponto de vista teórico, as categorias apresentadas inicialmente ganham as nomeações indicadas no quadro abaixo, onde as ideias passam a ser concebidas sob a ótica da abordagem cognitiva, os atores desempenham a função de mediadores, as relações são consideradas como redes e, por fimm, as ações transmutam-se em instrumentos.

Figura 7. Categorias de análise, segundo as contribuições teóricas

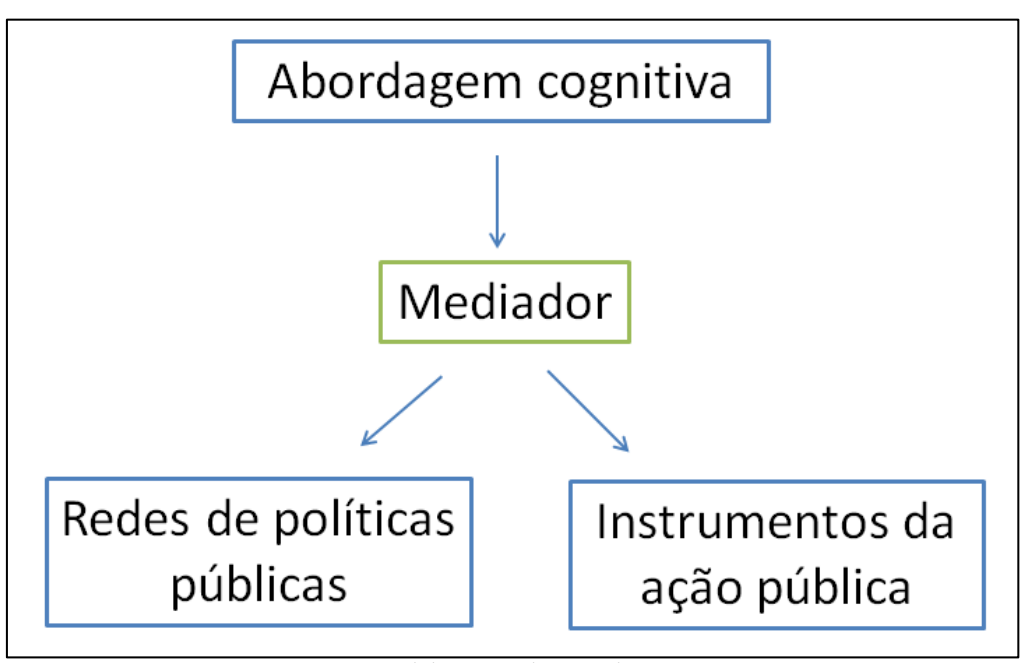

Fonte: Elaboração do próprio autor.

Ao longo desse capítulo foram utilizados, de maneira proposital, esquemas visuais, de modo a tentar "enquadrar" cada uma das teorias em definições, relações e fluxogramas muito objetivos. O esforço realizado pelo autor desta dissertação encontra paralelo nas próprias produções teóricas, uma vez que ambos tentam delimitar e, em parte simplificar, algo que é muito mais complexo e dinâmico. Assim, as teorias estão para a realidade, bem como as figuras desta dissertação estão para as teorias. 
O fato é que a realidade é caótica, as dinâmicas sociais e seus impactos na ação pública são complexos e nenhuma teoria por si só consegue explicar integralmente. 
2. Capítulo 2 - A política climática paulistana durante quatro governos: as ideias, os atores, as relações e as ações

O presente capítulo tem o propósito de apresentar ao leitor os principais acontecimentos da agenda climática paulistana durante o período de 2001 e 2016. Os fatos descritos aqui influenciaram, de uma maneira ou outra, a política de mudanças climáticas da cidade de São Paulo.

Trata-se de um processo e não de um momento único, específico ou estático no tempo. Ao mesmo tempo, não se trata de um processo linear, com etapas bem definidas, como apresentados nos modelos de ciclo de políticas públicas (LASSWELL, 1956). Pelo contrário, verifica-se que a realidade apresentada é caótica, com momentos em que a agenda climática ganha força e outros em que perde, com avanços gradativos, mas em grande parte limitados à existência de outras variáveis.

O caso paulistano em análise está circunscrito a um período de dezesseis anos, considerando, portanto, a passagem de quatro mandatos. O recorte inicial foi determinado pelo fato de que alguns elementos da política climática foram "germinados" naquele momento, enquanto o último ano do escopo representou o término do último mandato existente até o presente momento.

O quadro abaixo indica os prefeitos e os secretários da pasta do meio ambiente, bem como os grupos políticos aos quais pertenciam, os quais estiveram à frente da gestão municipal no período indicado.

Quadro 1. Relação dos prefeitos e secretários do meio ambiente da cidade de São Paulo

\begin{tabular}{|c|c|c|}
\hline \multirow{2}{*}{ Anos } & Prefeito(a) & $\begin{array}{c}\text { Secretário(a) do Verde e Meio } \\
\text { Ambiente }\end{array}$ \\
\cline { 1 - 1 } & \multirow{2}{*}{ Marta Suplicy (PT) } & Stela Goldenstein \\
\cline { 1 - 1 } 2002 & Adriano Diogo (PT) \\
\hline 2003 & José Serra (PSDB) & \multirow{2}{*}{ Eduardo Jorge (PV) } \\
\hline 2004 & Gilberto Kassab (PFL) & \\
\hline 2005 & &
\end{tabular}




\begin{tabular}{|c|c|c|}
\hline 2007 & & \\
\hline 2008 & \multirow{3}{*}{ Gilberto Kassab (DEM) } & \\
\hline 2009 & & \\
\hline 2010 & & \\
\hline 2011 & \multirow{2}{*}{ Gilberto Kassab (PSD) } & \\
\hline 2012 & & \\
\hline 2013 & \multirow{4}{*}{ Fernando Haddad (PT) } & Ricardo Teixeira (PV) \\
\hline 2014 & & Wanderley do Nascimento (PT) \\
\hline 2015 & & $\begin{array}{c}\text { Wanderley do Nascimento (PT) / José } \\
\text { Tadeu Candelária (PR) }\end{array}$ \\
\hline 2016 & & José Tadeu Candelária (PR) \\
\hline
\end{tabular}

Fonte: Elaboração do próprio autor.

Algumas inferências iniciais podem ser tecidas a partir das informações dispostas na tabela acima.

Do ponto de vista organizacional, dado o destaque já estabelecido no quadro acima à SVMA, é possível afirmar que a pasta do meio ambiente tem uma liderança e influência relevante na agenda climática municipal, embora as demais secretarias do governo municipal também tiveram, seguramente, participações relevantes, as quais serão detalhadas ao longo da dissertação.

Em termos institucionais, como o chefe da pasta ambiental é indicado e mantido no cargo pelo prefeito, o chefe de estado no âmbito municipal tem uma capacidade significativa de influência na questão climática. A continuidade ou alternância do chefe da pasta ambiental pode influenciar os avanços e a eventual consolidação da agenda climática, fato este que será mais aprofundado ao longo da dissertação. Em princípio, nota-se que no primeiro mandato (2001-2004) a SVMA teve dois secretários, enquanto no segundo e no terceiro governo, ou seja, durante um período de oito anos, o secretário do meio ambiente foi o mesmo, representando possivelmente a chefia mais longeva da pasta. Entretanto, no último governo (2013-2016) passaram pela Secretaria do Verde três diferentes secretários. 
Por fim, as relações políticas e partidárias representam uma variável importante de ser considerada durante as análises. Observase, por exemplo, que, do ponto de vista partidário, a prefeitura "navega" de um espectro mais à esquerda no primeiro governo, passando para um grupo de centro-esquerda e, em seguida, para a centro-direita, enquanto no último governo volta-se para o primeiro grupo mais à esquerda. A investigação que se desenvolve na presente produção científica deverá levar em consideração o impacto que essas relações político-partidárias podem ter gerado na construção da política climática do município de São Paulo.

Ainda de maneira introdutória ao capítulo, é importante dar destaque às demais produções acadêmicas que também trataram do caso da política de mudanças climáticas da cidade de São Paulo e que serão consideradas no processo de construção do presente capítulo. O quadro abaixo apresenta essas referências, seus respectivos campos de conhecimento, o período da política paulistana que analisaram e seu enfoque.

Em primeiro lugar, é possível notar que, ao compará-las com a presente dissertação, existem diferenças no campo de conhecimento (Ciência Ambiental), no período analisado (2001 a 2012) e no enfoque (abordagem teórica a partir da Sociologia Política), o que aumenta as possibilidades de se desenvolver uma contribuição científica relevante e inovadora com este trabalho. Cada uma dessas pesquisas apresenta contribuições relevantes que serão incluídas ao longo do desenvolvimento deste trabalho.

Quadro 2. Produções acadêmicas sobre a política de mudanças climáticas do município de São Paulo

\begin{tabular}{|c|c|c|c|}
\hline Autor & $\begin{array}{l}\text { Campo do } \\
\text { conhecimento }\end{array}$ & $\begin{array}{l}\text { Período } \\
\text { analisado }\end{array}$ & Enfoque \\
\hline Back (2012) & Ciência política & 2003 a 2009 & Implementação da agenda - agenda-setting (Kingdom) \\
\hline Furriela (2011) & $\begin{array}{l}\text { Administração } \\
\text { pública }\end{array}$ & 2005 a 2010 & Comitê Municipal de Mudança do Clima e Ecoeconomia \\
\hline Landin (2013) & Saúde Pública & 2010 a 2012 & $\begin{array}{l}\text { O setor da saúde na Política Municipal de Mudança do } \\
\text { Clima }\end{array}$ \\
\hline Cortese (2013) & Saúde Pública & 2009 a 2012 & Implantação da Política Municipal de Mudança do Clima \\
\hline Campos (2014) & Saúde Pública & - & $\begin{array}{l}\text { Articulação e integração das políticas de mudanças } \\
\text { climáticas dos municípios na RMSP, do Estado e da União }\end{array}$ \\
\hline
\end{tabular}


Implementação dos planos e programas previstos na Política Municipal de Mudança do Clima

Abaixo está a linha do tempo dos principais acontecimentos para compreender o caso em análise. Essa apresentação permite ter uma referência da cronologia dos fatos. Para o período de 1988 a 1997 são apresentados no box em roxo alguns acontecimentos internacionais que são anteriores ao estudo de caso, mas com grande relevância para a agenda climática. Para o período entre 2001 e 2016, anos dos quatro mandatos em análise nesta dissertação, na vertical são apresentados ano a ano os principais acontecimentos, diferenciados de duas maneiras diferentes. A depender do formato do box (retângulo, pentágono, triângulo ou círculo), trata-se de determinado nível, municipal, estadual, nacional ou internacional. Cada cor relacionada determinado acontecimento com um tipo de categoria de análise: os atores-chave, os fóruns de participação, as redes de articulação, os instrumentos da ação pública e as ações e programas implementados.

Considerar os acontecimentos entre os diferentes níveis de política é relevante, uma vez que é possível identificar um determinado nível de influência entre eles, o qual será explorado ao longo da dissertação. Ao mesmo tempo, o destaque aos atores, redes, fóruns, instrumentos e ações/programas também é importante, dado que representa um indicador do ponto de vista da abordagem teórica, o que permitirá interpretar e compreender o processo de construção da política climática paulistana.

Esse capítulo tem, portanto, como objetivo, apresentar ao leitor o resgate histórico dos principais acontecimentos relacionados à política climática paulistana, direta ou indiretamente. Dessa maneira, ele está organizado em cinco subseções, sendo a primeira dedicada ao contexto internacional prévio e as quatro demais para cada um dos mandatos dos prefeitos da cidade de São Paulo. 
Figura 8. Linha do tempo (1988-2016) com os destaques da política climática paulistana

Excluído:

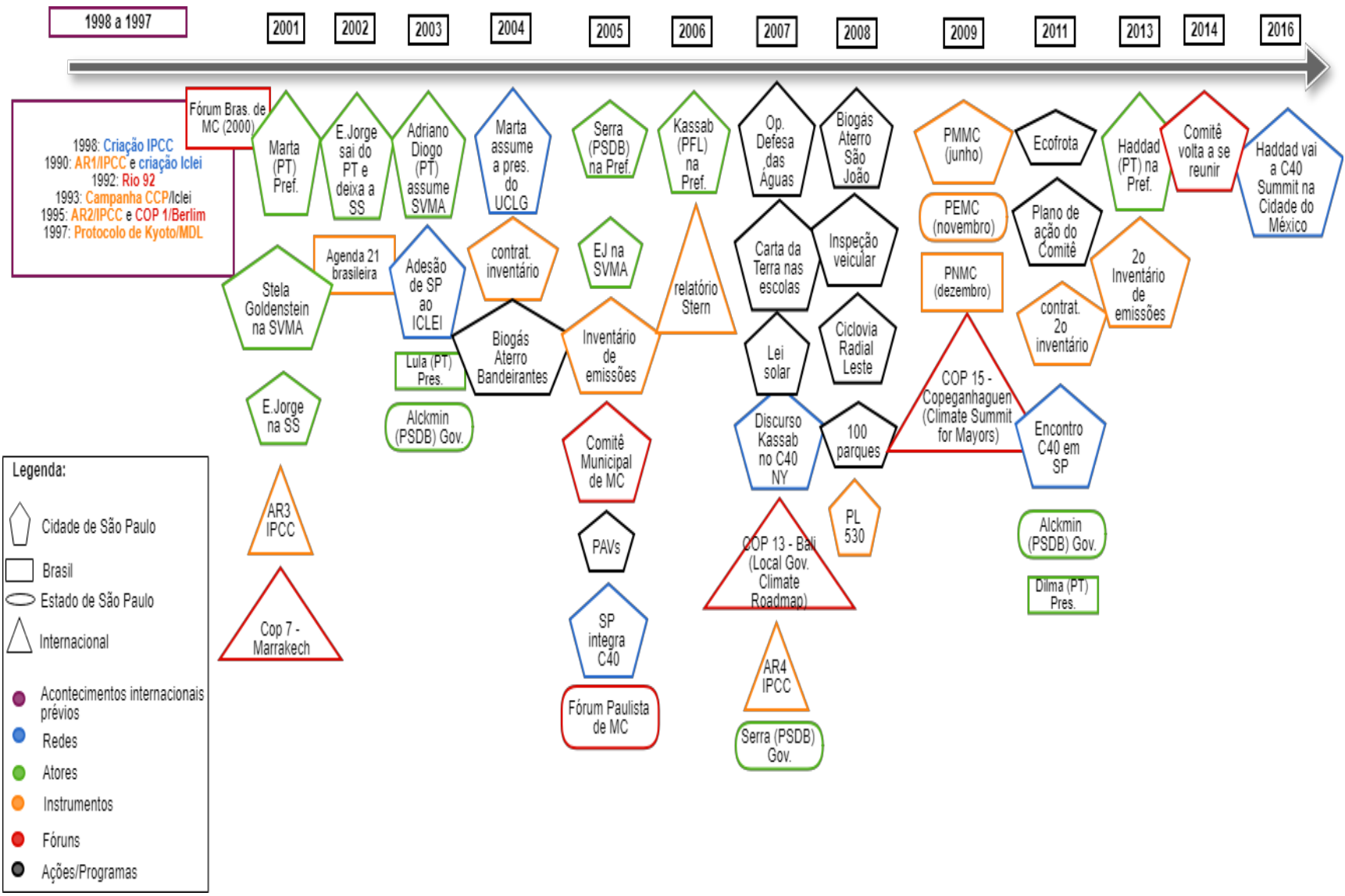

Fonte: Elaboração do próprio autor. 


\subsection{Contexto internacional prévio}

Nota-se que a linha do tempo se inicia em 1988, com a criação do Painel Intergovernamental sobre Mudanças Climáticas (IPCC na sigla em inglês), apesar de existirem acontecimentos anteriores que podem ser considerados relevantes para o campo da sustentabilidade, como o livro Silent Spring, de Rachel Carson, publicado em 1962, a Conferência de Estocolmo, em 1972, e o relatório Brundtland - Our Common Future - em 1987. A escolha do marco inicial a partir de 1988 se justifica pelo fato de o IPCC representar a principal referência científica no campo das mudanças climáticas, consolidando-se enquanto uma rede epistêmica de grande relevância, em que os principais cientistas, de diferentes áreas, se reúnem. O IPCC é uma das mais reconhecidas fontes de dados técnicos sobre as causas e impactos do aquecimento global, com uma alta capacidade de influência política.

A principal ferramenta utilizada por essa rede epistêmica internacional para se comunicar com o resto da sociedade são os chamados Assessment Reports (AR) - Relatórios de Avaliação, nos quais, além de fornecer uma quantidade de informações técnicas de maneira bastante detalhada, traduzem o conhecimento em um Summary for policymakers, que, a partir de uma linguagem mais compreensível, tem como objetivo influenciar a decisão dos agentes políticos. $\mathrm{O}$ primeiro relatório do IPCC (AR1) foi divulgado em 1990 e serviu como base relevante de informações para os preparativos da Eco 92 ou Rio 92, que aconteceria dali há dois anos. A linha do tempo dá destaque a todos os ARs produzidos pelo IPCC ao longo dos anos, sendo o AR2 divulgado em 1995, o AR3 em 2001 e o AR4 em 2007.

Todo esse conjunto de relatórios divulgados pela principal entidade científica no campo das mudanças climáticas teve uma importância significativa, sob diferentes ângulos. $\mathrm{O}$ posicionamento do IPCC por meio de seus relatórios gerou impactos em nível global, de modo que as mudanças climáticas ganharam força própria enquanto campo de conhecimento, combatendo o ceticismo a respeito da influência antrópica nesse processo e indicando as causas e possíveis soluções em termos de mitigação e adaptação. Ao longo da dissertação será possível avaliar como esses relatórios influenciaram no âmbito da política local de São Paulo. De todo modo, é possível identificar preliminarmente os ARs como importante instrumento comunicacional, seja para a comunidade científica, seja para um leque de público mais amplo, incorporando os políticos e a sociedade no geral. 
Do ponto de vista da comunicação, é possível notar como as mudanças climáticas foram paulatinamente sendo compreendidas, divulgadas e ganhando notoriedade nos meios de comunicação. Um exemplo dessa circunstância é a capa da renomada revista americana Time, em outubro de 1987, um ano antes da criação do IPCC, conforme ilustra a imagem abaixo. Na capa é possível observar o alerta para o fenômeno do aquecimento global e o aumento do furo na camada de ozônio.

Figura 9. Capa da revista Time em outubro de 1987

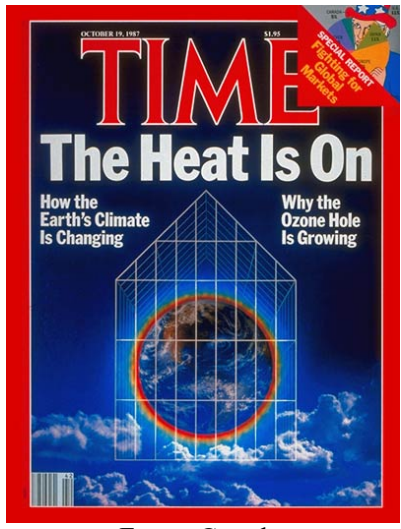

Fonte: Google.

Ainda em 1990 foi fundado o ICLEI - Local Governments for sustainability, uma das mais influentes associações mundiais de governos locais para o desenvolvimento sustentável. Um dos objetivos da instituição é gerar intercâmbios entre governos locais, representando, assim, uma relevante rede internacional no campo das políticas de mudanças climáticas. Em 1993 o ICLEI lançou uma campanha internacional, denominada Cities for Climate Protection (CCP), a qual estabelecia que os atores que a subscrevessem estariam se comprometendo com cinco compromissos, chamados de milestones: produção de um inventário de emissões de GEEs, estabelecimento de meta de redução de emissões, desenvolvimento de um plano de ação local, implementação de políticas, monitoramento e avaliação de resultados.

A atuação do ICLEI no Brasil tem grande relevância, tendo exercido importante influência no contexto local paulistano. Em 2003 a cidade de São Paulo aderiu ao ICLEI e, consequentemente, comprometeu-se com os compromissos da campanha CCP. Cada cidade, ao 
aderir à campanha, assumia seus cinco compromissos, relacionados à construção de uma política climática. Nesse sentido, será possível notar que, no âmbito da cidade de São Paulo, ao menos parte desses compromissos foram perseguidos, de modo que a campanha CCP do ICLEI se constitui como um instrumento da ação pública paulistana de ordem normativa.

Conforme Lascoumes e Simard (2011) apontam, a observação da incidência de instituições internacionais em contextos nacionais permite identificar que os instrumentos nesses casos atuam normalmente, de modo a transferir ou compartilhar modelos de políticas públicas que podem ser reinterpretados ou adaptados segundo o contexto local. Conforme será descrito mais adiante no texto, a campanha CCP e o próprio ICLEI incidem diretamente na formulação dos instrumentos locais de São Paulo referentes à agenda climática.

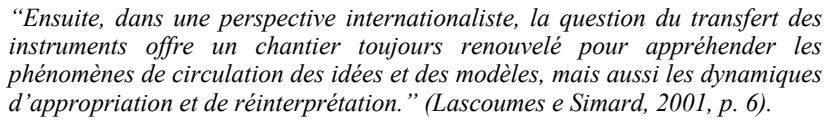

Dando prosseguimento à análise da linha do tempo em seu nível internacional, em 1992 aconteceu a Rio 92, cujo nome oficial era Conferência das Nações Unidas sobre o Meio Ambiente e Desenvolvimento, também conhecida como Cúpula da Terra. O fato de esse encontro internacional acontecer no Brasil gerou um relativo protagonismo do país tanto nas negociações em si mesmas quanto em relação à exposição do Brasil para o resto do mundo. Foi durante as negociações da Rio 92 que foi criada a Convenção-Quadro das Nações Unidas sobre Mudança do Clima (UNFCCC em inglês), com a assinatura de 166 Estados-nação, tendo como objetivo estabilizar a concentração de gases de efeito estufa (GEEs) na atmosfera, resultante dos impactos do aquecimento global, alerta este identificado pela comunidade científica, especialmente no relatório divulgado pelo IPCC em 1990.

Compreender o objetivo e o contexto de nascimento da UNFCCC é central para o escopo desta dissertação, uma vez que o órgão supremo dessa convenção é exatamente a Conferência das Partes (COP), fórum anual que reúne os Estados-nação e onde são negociados os acordos internacionais específicos sobre clima. Do ponto de vista do sistema internacional, a COP é a principal arena decisória sobre as políticas de mudanças climáticas, de modo que seus acordos finais são vinculantes, ou seja, todos os países que assinarem têm a obrigação de cumprir o que foi estipulado. Existem diversas críticas sobre a capacidade decisória desse espaço de negociação, uma vez que seus resultados dependem de amplo consenso de uma multiplicidade de atores. De 
todo modo, o que a linha do tempo destaca são alguns desses encontros anuais, sobretudo quando é possível identificar relações entre as decisões tomadas no âmbito de determinada COP e a realidade local da cidade de São Paulo. A primeira dessas negociações internacionais aconteceu em 1995, em Berlim, mesmo ano em que foi divulgado o AR2 do IPCC.

Aconteceu no Japão, em 1997, a $3^{\text {a }}$ Conferência das Partes, cujo resultado final desse encontro chama-se Protocolo de Kyoto, tratado internacional que criou, a partir de seu artigo $12^{\circ}$, o relevante instrumento do Mecanismo de Desenvolvimento Limpo (MDL). Assim, as partes signatárias acordaram que, por meio do MDL, os países em desenvolvimento podem vender créditos de carbono para países desenvolvidos (Anexo I) por meio de iniciativas de redução ou sequestro de emissão de GEEs na atmosfera. Uma das principais críticas que surgiram ao término das negociações de Kyoto foi a ausência dos Estados Unidos da América, principal emissor de GEE, no acordo final.

Ainda assim, o Protocolo de Kyoto criou um importante instrumento de ordem econômica para as políticas climáticas, com impactos nas ações dos Estados e de seus governos subnacionais. A meta estabelecida foi de diminuição em $70 \%$ as emissões de GEE em todo mundo, com o prazo de vigência até 2012. Nota-se que o tratado foi negociado em 1997 e sua vigência se iniciou somente em 2005.

O MDL, conforme descrito mais a frente, será um elemento central no desenvolvimento de determinadas iniciativas do município de São Paulo, contribuindo, inclusive, para a construção de um discurso que possibilitou uma adesão maior à agenda climática de atores que, a princípio, não tinhamram proximidade com essa questão. No trecho abaixo, Giddens (2010) explora a maneira como os países em desenvolvimento tiraram proveito do MDL, sobretudo em projetos de HFCs (gases de refrigeração, utilizados em aparelhos como ar-condicionado), N2O (óxido nitroso) e gás de aterros sanitários. Nesse ínterim, dado que o Brasil é signatário do Protocolo de Kyoto ${ }^{2}$, como demonstrado no diagrama, São Paulo também exerceu protagonismo no âmbito brasileiro, conforme será descrito mais à frente:

"O MDL entrou lentamente em vigor, pois poucos países se dispunham a agir enquanto o Protocolo não fosse finalmente ratificado [em 2005]. Havia cerca de 700 projetos em meados de 2007 , a maioria deles situada nos quatro maiores

${ }^{2}$ A ratificação do Protocolo de Kyoto pelo Congresso brasileiro só ocorre em agosto de 2002. 
países em desenvolvimento: China, Índia, Brasil e África do Sul" (Giddens, 2010, p. 234).

Ao fazer um balanço dos principais acontecimentos no âmbito internacional durante o período de 1988 e 1997, é possível identificar um processo a partir do qual as mudanças climáticas ganham relevância política e alcançam um nível de importância no imaginário social, de modo que passam a representar, ao mesmo tempo, um campo do conhecimento e de relações políticas próprio.

Do ponto de vista teórico, a abordagem cognitiva disponibiliza um conjunto de ferramentas para compreender como as mudanças climáticas se estabeleceram enquanto ideia, explorando os valores e conceitos que as sustentam. É igualmente importante notar que, ao se fortalecer e se institucionalizar enquanto campo próprio, as mudanças climáticas vão paulatinamente sendo interpretadas como uma responsabilidade compartilhada por um conjunto grande de atores, entre eles os governos locais. Nesse ínterim, determinados aspectos têm relevância fundamental.

Em primeiro lugar, o IPCC emerge em 1988 como a principal referência científica no assunto, publicando periodicamente seus Assessment Reports (ARs). A partir desse importante instrumento de ordem técnica e comunicacional, o IPCC, principal rede epistêmica do campo das mudanças climáticas, assegurou a influência antrópica no processo de aquecimento global, identificando as principais causas e projetando os possíveis impactos. Nesse sentido, seus conteúdos exerceram uma dupla função: organizar e legitimar um conhecimento técnico e, ao mesmo tempo, traduzi-lo de modo que a sociedade tomasse conhecimento e começasse a se sensibilizar sobre a questão.

Em seguida, a Rio 92 é representativa sob dois aspectos: inicialmente, por representar um momento de encontro onde autoridades de todo o mundo se reuniram para debater os desafios ambientais, e, em segundo lugar, pelo fato de ter ocorrido no Brasil, o que gerou um conjunto de movimentos políticos e sociais em território nacional.

Um dos principais desdobramentos desse fórum internacional foi a criação da UNFCCC, estrutura a partir da qual se realizam as COPs. A partir de então, mais do que um fórum de discussão ou consulta, emerge no âmbito internacional a principal arena decisória sobre as negociações e acordos climáticos. O importante diferencial das COPs é seu caráter vinculante, sendo que um de seus mais significativos resultados foi o Protocolo de Kyoto, acordado em 1997, 
a partir do qual foi criado o instrumento do MDL, que representa um importante mecanismo de ordem econômica, com impactos significativos nas políticas climáticas, inclusive em âmbito local.

Por fim, aterrissando na maneira como os governos locais se posicionam no quadro climático internacional, destaca-se o ICLEI, criado em 1990, enquanto rede internacional que aproxima e conecta cidades de diferentes partes do mundo para tratar de determinados desafios. Entre eles destaca-se o desafio climático, sobre o qual o ICLEI exerceu importante papel a partir de sua campanha Cities for Climate Protection (CCP), lançada em 1993, que pode ser compreendida como instrumento de ordem normativa, indicando um conjunto de compromissos que as cidades participantes deveriam cumprir, entre eles, por exemplo, a publicação de um inventário de emissões de GEEs.

Considerando as categorias de análise teóricas propostas aqui, o quadro abaixo resume os principais aspectos do contexto internacional prévio analisado.

Quadro 3. Tabela das ideias redes, fóruns e instrumentos do contexto internacional prévio

\begin{tabular}{|c|l|}
\hline \multirow{2}{*}{ Ideias } & $\begin{array}{l}\text { Mudanças climáticas se institucionalizam e ganham força enquanto } \\
\text { ideia no campo científico e político internacional }\end{array}$ \\
\hline \multirow{2}{*}{ Redes } & IPCC (epistêmica) \\
\cline { 2 - 2 } & ICLEl (política) \\
\hline \multirow{2}{*}{ Fóruns } & Rio 92 \\
\cline { 2 - 2 } & COPs (arena) \\
\hline \multirow{3}{*}{ Instrumentos } & Assessment Reports (AR) do IPCC (técnico) \\
\cline { 2 - 2 } & Sumário dos Ars (comunicacional) \\
\cline { 2 - 2 } & Cities for Climate Protection (CCP) do Iclei (normativo) \\
\cline { 2 - 2 } & Mecanismo de Desenvolvimento Limpo (MDL) (econômico) \\
\hline
\end{tabular}

\subsection{Gestão da prefeita Marta Suplicy (PT) (2001-2004)}

Em 2001 inicia-se a gestão da prefeita Marta Suplicy na prefeitura de São Paulo, tendo como vice Hélio Bicudo - um dos fundadores do PT -, com uma chapa que havia vencido no segundo turno as eleições de outubro de 2010 contra Paulo Maluf (PPB), que fora prefeito da cidade entre 1993 e 1997.

Marta é psicanalista de formação, filiada ao Partido dos Trabalhadores (PT) desde 1981, um ano depois da fundação dele. Em 1994, Marta elegeu-se deputada federal pelo PT. Em 1998 
concorreu ao governo de São Paulo, sem sucesso. Em 2007, após sua passagem pela prefeitura de São Paulo, viria a ser Ministra do Turismo no governo Lula.

Logo em janeiro de 2001 a prefeita de São Paulo criou a Secretaria Municipal de Relações Internacionais (SMRI), a partir da Lei Municipal n. 13.165/2001, de autoria do Executivo, tendo como objetivo coordenar convênios e projetos de cooperação internacional, inserindo a cidade na dinâmica das negociações internacionais. Esse fato é relevante, uma vez que historicamente, ao menos no Brasil, há uma prevalência da presença do Estado brasileiro e não de entes subnacionais nas negociações internacionais. Nesse sentido, a cidade de São Paulo se colocou em uma posição de relativo protagonismo, pois estabeleceu uma estratégia de inserção em diferentes fóruns internacionais a partir do trabalho de uma secretaria específica. A análise da criação e da institucionalização da política climática ao longo dos anos permitirá observar a participação da SMRI como instrumento da estrutura organizacional da prefeitura. De todo modo, já se identifica uma orientação estratégica oriunda da própria prefeita Marta de inserir o município em fóruns internacionais a partir desse instrumento, qual seja, a SMRI.

Nos quatro primeiros anos de existência da SMRI já foi estabelecida uma determinada rotatividade em seu comando. Durante os dois primeiros anos, Jorge Eduardo Levi Mattos, que tinha uma vinculação muito próxima ao PT, além de ser muito próximo à Marco Aurélio Garcia, também do PT e então Secretário Municipal da Cultura e vice-presidente do partido ${ }^{3}$, ocupou o cargo de secretário. Nos dois últimos anos do mandato de Marta Suplicy, o internacionalista Kjeld Jakobsen passou a assumir a liderança da pasta. Do ponto de vista da estratégia de inserção internacional do município, a SMRI é importante de ser notada nesse processo.

Nos dois primeiros anos de seu mandato, Marta contou com a liderança de Stela Goldenstein na pasta da Secretaria do Verde e Meio Ambiente (SVMA). Goldenstein é geógrafa de formação, com uma carreira profissional dedicada ao meio ambiente, tendo inclusive já ocupado o cargo de secretária-adjunta e Secretária Estadual deMeio Ambiente ao entre 1995 e 1999. O fato de Goldenstein ocupar uma secretaria em um governo comandado pelo PT, de certa, causa estranheza, uma vez que sua aproximação política sempre se estabeleceu com políticos do PSDB, em especial com José Serra. De todo modo, o que pode ser observado ao longo da análise é que

\footnotetext{
${ }^{3}$ Durante os mandatos de Lula e Dilma na presidência da república, Marco Aurélio viria a ser assessor especial de
} da Presidência da República para assuntos internacionais. 
Stela teve uma participação relevante na SVMA em determinadas ações relacionadas à agenda climática.

Ainda no início de 2001, Marta convidou Eduardo Jorge (PT) para liderar a Secretaria Municipal de Saúde (SMS). Eduardo Jorge havia sido um dos fundadores do Partido dos Trabalhadores em 1980, além de já ter sido Secretário Municipal de Saúde entre 1989 e 1990, durante a gestão de Luiza Erundina, à época também do PT. Jorge tem a formação em Medicina, com especialização em Saúde Pública, sendo médico sanitarista de carreira da Secretaria de Saúde do Estado de São Paulo desde 1976. Jorge viria a ser uma figura central na construção da política climática, especialmente na próxima gestão que viria a comandar a Prefeitura. Por ora, é importante mencionar que Jorge ficou na Secretaria Municipal de Saúde até 2002 e já em 2003 viria a se desfiliar do PT.

O ano de 2003 pode ser considerado como o marco inicial da construção paulatina da política climática paulistana, por causa da institucionalização de um instrumento central de toda a política: o inventário de emissões de gases de efeito estufa. Foi nesse ano que a SVMA estabeleceu uma parceria técnica com o ICLEI, a partir da Portaria SVMA 35/03, publicada no Diário Oficial do Município em 15 de abril de 2003. Por meio dessa portaria foi instituída uma articulação entre a cidade e a ONG, que viria a ser de suma importância para avanços em termos de políticas públicas paulistanas. No âmbito dessa parceria técnica entre São Paulo e ICLEI, a cidade se comprometeu em estabelecer as cinco milestones da campanha CCP. A primeira etapa desses cinco compromissos determina a necessidade de o município publicar oficialmente seu inventário de emissões de gases de efeito estufa. É a partir do inventário, que representa um instrumento orientador central da agenda climática, que a política climática paulistana começa a se estabelecer e a ganhar "corpo" próprio, ainda que nesse momento, em 2003, isso ainda não seja uma realidade.

Em termos dos atores protagonistas nessa construção, algumas ressalvas devem ser feitas. O relacionamento entre o ICLEI e a SVMA começou a se estruturar no início do mandato de Goldenstein à frente da secretaria, enquanto, em relação ao ICLEI, quem estava coordenando os trabalhos era Laura Valente, diretora regional para América Latina e Caribe. Ambas já haviam trabalhado juntas quando Fábio Feldmann era Secretário Estadual de Meio Ambiente e Stela Goldenstein era sua adjunta. Para além da aproximação entre as instituições, destaca-se também que foi nesse período que as tratativas para a contratação do inventário de emissões tiveram início. Laura viria a se consolidar como um ator importante para o processo de construção da política 
climática da cidade de São Paulo, uma vez que coordenou os trabalhos do ICLEI entre 2003 e 2011.

No momento da formalização da relação entre SVMA-ICLEI e da contratação para elaboração do inventário, que viria a se concretizar um ano depois, em 2004, quem estava no comando da SVMA era Adriano Diogo. Quadro do PT, Adriano é geólogo e sanitarista, e já havia exercido o cargo de vereador da cidade durante dois mandatos (1998-2001 e 2001-2002).

Isso posto, pode-se identificar a importância inicial do ICLEI enquanto uma rede internacional que busca induzir um comportamento do governo municipal em direção à agenda climática. Vale lembrar que a campanha internacional do Iclei, a CCP, também pode ser considerada um instrumento indutor para o avanço da agenda climática paulistana, uma vez que, a partir dela e seus respectivos compromissos, a cidade de São Paulo contratou seu primeiro inventário de emissões de GEEs.

No último ano de mandato da prefeita Marta Suplicy alguns acontecimentos relacionados à questão climática merecem atenção. O primeiro deles é o início da operação da Unidade Térmica de Energia (UTE), no Aterro Sanitário Bandeirantes, localizado no bairro de Perus, na zona norte da cidade. O Aterro Bandeirantes iniciou seu funcionamento em 1979 e, desde então, representou um dos principais destinos da produção de resíduos da cidade de São Paulo. O aterro é o maior da América Latina, com 140 hectares de área, e recebe em média a metade de toda produção diária de lixo dos cerca de 11 milhões de habitantes da cidade. A grande novidade a partir do ano de 2004 foi o aproveitamento energético, instalado a partir de 400 pontos de captura, que retiram o metano proveniente da decomposição do lixo. Desde 2001 a Prefeitura de São Paulo concedeu à empresa Biogás, durante o período de quinze anos, a exploração do aproveitamento energético a partir da captura do gás do metano do aterro.

O aproveitamento energético dos gases que saem de aterros sanitários começou a atrair a atenção de diversos atores políticos em países em desenvolvimento com o objetivo de aproveitar o instrumento econômico do MDL, previsto no Protocolo de Kyoto, tanto é que, em 2004, iniciouse a captura do metano no Aterro Bandeirantes em São Paulo e já em 2007 a Prefeitura de São Paulo realizou leilões para a venda dos créditos de carbono desse mesmo aterro. Essa ocasião foi a primeira experiência mundial de leilão de Reduções Certificadas de Emissões realizada por uma bolsa de valores, no caso a BM\&F. Foram leiloadas 808.450 toneladas de dióxido de carbono 
equivalente (CO2e), correspondentes ao período de 2004 a 2006, gerados nos termos do Mecanismo de Desenvolvimento Limpo (MDL) pelo Projeto Bandeirantes de Gás de Aterro e Geração de Energia e emitidos pelo Conselho Executivo do MDL (ONU), arrecadando R\$ 34 milhões.

No contexto do desenvolvimento de projetos vinculados ao mecanismo do MDL, é importante destacar que o Brasil ratificou o Protocolo de Kyoto em 2002, durante o governo de Fernando Henrique Cardoso (PSDB), mas a vigência do acordo internacional se iniciou somente em 2005. De todo modo, nota-se que a cidade de São Paulo esteve na vanguarda da utilização do MDL: (i) ao menos desde 2001 quando, durante o $1^{\circ}$ ano de mandato de Marta Suplicy (PT), já havia avançado na concessão dos direitos de exploração de aproveitamento energético à iniciativa privada; (ii) quando em 2004 começou a operação de aproveitamento energético no aterro Bandeirantes; (iii) quando em 2007 foi realizado o primeiro leilão de créditos de carbono desse tipo de projeto.

Dessa forma, em relação ao aproveitamento energético do aterro Bandeirantes, nota-se sua relação direta com uma política de mitigação de emissões de gases de efeito estufa, aproveitando, sobretudo, a possibilidade que o instrumento econômico internacional do MDL representava em termos de ganhos financeiros para os cofres da Prefeitura. É importante destacar que as negociações a respeito dessa ação se iniciaram logo no começo da gestão de Marta, quando Stela Goldenstein estava na SVMA.

Seguindo a análise da linha do tempo, em maio do ano de 2004, a prefeita Marta Suplicy (PT), em seu último ano à frente da gestão municipal, foi eleita para a co-presidência da United Cities and Local Governments (UCLG). A UCLG é uma organização que congrega representações de diversos governos locais, com o objetivo de defender seus interesses comuns nas negociações internacionais. A organização foi criada em maio de 2004 e elegeu como co-presidentes os prefeitos de Paris, São Paulo e Pretória para o mandato de 2004-2007.

Do ponto de vista das iniciativas que viriam a ser implementadas na cidade de São Paulo nas agendas relacionadas à problemática do clima, as análises encontradas na produção acadêmica existente não apontam para uma relevância substancial e participação efetiva da UCLG, diferentemente do ICLEI, por exemplo. No entanto, importa ressaltar aqui a relevância dessa articulação do ponto de vista da estratégia de inserção do município em fóruns internacionais. 
Nesse sentido, é importante lembrar que em 2004 fazia menos de quatro anos que a SMRI havia sido criada. Além disso, as declarações de Marta Suplicy à época defendiam a necessidade de maior descentralização das tomadas de decisão e a maior capacidade de as cidades efetuarem empréstimos, especificamente com o Banco Mundial, sem depender de seus governos nacionais o presidente do Brasil naquela ocasião era Luiz Inácio Lula da Silva (PT), do mesmo partido de Marta Suplicy.

Ainda no mês de maio de 2004 há um acontecimento muito importante para a conjuntura em análise: a concretização da contratação do $1^{\circ}$ inventário de emissões de gases de efeito estufa do município de São Paulo. O inventário de emissões é considerado um dos passos iniciais na agenda de mudanças climáticas para qualquer ação de mitigação, uma vez que somente a partir de um diagnóstico detalhado, identificando a ordem de grandeza e os principais setores contribuintes, que se pode estabelecer um plano de ação assertivo.

Em São Paulo esse trabalho se deu a partir do Contrato SVMA nº 14/04, em que a Secretaria do Verde e Meio Ambiente incumbiu a tarefa ao Centro de Estudos Integrados sobre Meio Ambiente e Mudanças Climáticas (Centro Clima), da Coordenação dos Programas de PósGraduação em Engenharia (COPPE) da Universidade Federal do Rio de Janeiro (UFRJ). Conforme descrito no Diário Oficial do Município de 20 de maio de 2004 (p. 31), a contratação da COPPE/UFRJ teve como objetivo o provimento de consultoria técnica especializada que apoiasse na elaboração de uma ₹olítica Pública de Redução de Emissões de Gases de Efeito Estufa para o município de São Paulo, com vistas à sua participação no Mecanismo de Desenvolvimento Limpo - MDL e no mercado de carbono em geral". O prazo máximo para a apresentação dos estudos foi estabelecido em oito meses e o valor total do contrato foi de $\mathrm{R} \$ 772.818,20$. Desde o início notase que há um interesse explícito, citando o potencial de ganhos econômicos a partir do MDL, no aproveitamento dos possíveis benefícios econômicos que determinadas iniciativas poderiam trazer para os cofres da cidade.

Pode-se afirmar que a contratação do inventário está direta ou indiretamente relacionada aos compromissos assumidos pela Prefeitura de São Paulo ao aderir à campanha CCP do ICLEI há 13 meses atrás, em abril de 2003. A contratação do inventário foi feita no último ano da gestão de Marta Suplicy na prefeitura e de Adriano Diogo na SVMA. 
Em outubro de 2004 ocorreram as eleições municipais, cuja disputa foi para o segundo turno. Marta Suplicy (PT) concorreu à reeleição da Prefeitura, tendo Rui Falcão como seu vice, contra José Serra (PSDB), cujo vice era Gilberto Kassab (PFL). A chapa Serra/Kassab venceu as eleições com $54,86 \%$ dos votos.

De maneira geral, é possível dizer que as mudanças climáticas enquanto um conjunto de valores, enquanto ideia, começam a aparecer em determinadas ações pontuais no governo municipal de São Paulo. Diretamente, destaca-se o inventário de emissões, uma vez que trata explicitamente das mudanças climáticas como desafio a ser diagnosticado. Indiretamente, destacase o aproveitamento energético do aterro Bandeirantes e o benefício financeiro via MDL, dado que suas ações contribuem para a redução nas emissões de GEEs.

Em termos de atores, pode-se dizer que a prefeita Marta Suplicy tem uma importância indireta para a agenda climática por causa das possibilidades que ela viabilizou e abriu para que o município de São Paulo tivesse uma inserção internacional, sobretudo a partir da criação da SMRI. Ainda em relação aos atores, os dois secretários que ocuparam a pasta da SVMA tiveram atuação destacada. Stela Goldenstein iniciou tanto a relação do município com o ICLEI, bem como iniciou os preparativos que permitiram o aproveitamento energético do aterro sanitário e a própria contratação do inventário. Adriano Diogo, por sua vez, conseguiu formalizar a parceria com o ICLEI e viabilizar a assinatura do contrato para elaboração do inventário.

Do ponto de vista dos instrumentos da ação pública, ressaltam-se quatro instrumentos para o período do mandato de Marta Suplicy. A Secretaria Municipal de Relações Internacionais pode, desde já, ser considerada um relevante instrumento da estrutura organizacional da prefeitura, pois permitiu, conforme será detalhado ao longo da dissertação, uma inserção internacional da cidade, que foi importante para a agenda climática.

Nota-se, assim, que dois instrumentos que haviam sido citados na seção anterior dessa dissertação, quando foi abordado o contexto internacional prévio, foram incorporados e utilizados no âmbito da realidade local de São Paulo. Tanto a campanha internacional do ICLEI, chamada Cities for Climate Protection (CCP), quando o Mecanismo de Desenvolvimento Limpo (MDL), que surgiu a partir do Protocolo de Kyoto, tiveram um impacto direto já desde o início da construção da política climática paulistana. A campanha CCP teve importante participação para que o município de São Paulo contratasse seu inventário de emissões, enquanto o MDL foi 
interpretado pela prefeitura como uma oportunidade de aferir ganhos econômicos, o que possibilitou um avanço em termos de aproveitamento energético a partir do metano de aterros sanitário. Por causa disso, ambos os instrumentos são destacados tanto na tabela abaixo quanto na anterior.

O quarto instrumento desse período é o próprio inventário de emissões, contratado pela prefeitura e elaborado pela UFRJ. Esse documento pode ser considerado um instrumento orientador de toda a política climática que viria a ser planejada e implementada no âmbito local paulistano.

Em relação às redes, duas devem ser destacadas. A primeira, a UCLG, tem uma relevância sobretudo por representar uma das primeiras experiências em termos de inserção internacional do município, apesar de seu baixo impacto direto nas políticas sobre mudanças climáticas. A segunda, o ICLEI, teve uma influência direta na construção da política climática paulistana, sendo uma importante instituição ao longo dos anos em análise.

Por fim, a ação prática que foi implementada no governo Marta foi o início do aproveitamento energético do gás metano expelido no aterro sanitário Bandeirantes. Apesar de o leilão de vendas de créditos, via MDL, ocorrer somente em 2007, é importante ressaltar que esse processo se iniciou ainda no mandato de Marta Suplicy.

Abaixo, encontra-se a tabela que lista a ideia, os atores, os instrumentos, as redes e a ação do período em análise.

Quadro 4. Tabela com a ideia, os atores, os instrumentos, as redes e as ações do governo Marta Suplicy (2001-2004).

\begin{tabular}{|c|l|}
\hline \multirow{4}{*}{ Ideia } & $\begin{array}{l}\text { As mudanças climáticas começam a aparecer em ações } \\
\text { pontuais nas políticas municipais de São Paulo }\end{array}$ \\
\hline \multirow{4}{*}{ Atores } & Marta Suplicy \\
\cline { 2 - 2 } & Stela Goldenstein \\
\cline { 2 - 2 } & Adriano Diogo \\
\cline { 2 - 2 } Instrumentos & Laura Valente \\
\hline & SMRI (organizacional) \\
\cline { 2 - 2 } & Campanha ICLEI CCP (normativo) \\
\cline { 2 - 2 } & MDL (econômico) \\
\hline \multirow{2}{*}{ Redes } & Inventário de emissões (orientador) \\
\hline & UCLG (política) \\
\hline
\end{tabular}


Fonte: Elaboração do próprio autor.

\subsection{Gestão do prefeito José Serra (PSDB) (2005-2006)}

O ano de 2005 marca o início da gestão de José Serra (PSDB) à frente da Prefeitura de São Paulo, tendo como seu vice Gilberto Kassab (PFL). A chapa PSDB/PFL logrou vencer as eleições municipais de 2004 contra a tentativa de reeleição da ex-prefeita Marta Suplicy (PT).

Serra atuou no movimento estudantil durante o período em que esteve na universidade, sendo um dos fundadores da Ação Popular, organização política de esquerda e presidente da União Nacional dos Estudantes (UNE), exilando-se fora do país durante o período da ditadura militar. Em 1983 exerceu o cargo de Secretário Estadual de Planejamento de São Paulo, na gestão do governador Franco Montoro (PMDB). Em 1988 José Serra foi um dos fundadores do Partido da Social Democracia Brasileira (PSDB), quando, no mesmo ano, elegeu-se deputado federal para a Assembleia Constituinte. Durante a presidência de Fernando Henrique Cardoso (PSDB), Serra foi Ministro do Planejamento e da Saúde. Sua trajetória político-partidária representa variáveis de análise que auxiliam na compreensão de determinados acontecimentos observados no estudo de caso desta dissertação.

$\mathrm{Na}$ Secretaria do Verde e Meio Ambiente estava Eduardo Jorge, político que pertencia aos quadros do Partido dos Trabalhadores até o ano de 2003, quando integrou o Partido Verde, que historicamente tinha um vínculo com a área da saúde. O que as pesquisas bibliográficas indicam é que o então prefeito Serra, ao vencer as eleições, buscou no PV um quadro com experiência administrativa para comandar os trabalhos da SVMA. Apesar de o PV não ter integrado a coligação vencedora, o partido deu apoio à candidatura de Serra no momento do segundo turno. Nesse contexto, Eduardo Jorge, que havia ingressado no PV há pouco tempo, mas tinha experiência de dois mandatos na Secretaria de Saúde, foi o escolhido para a Secretaria do Meio Ambiente.

Outro ponto interessante de se notar nessa transição entre governos é que, apesar de política e ideologicamente pertencerem a grupos opostos - PT de um lado e PSDB de outro -, houve uma continuidade nos instrumentos da ação pública em mudanças climáticas que tiveram seu início no mandato de Marta Suplicy. Entre eles, destaca-se o inventário de emissões de gases de efeito estufa, que havia sido contratado no último ano do mandato da petista e foi publicado em 2005, 
tendo uma relevância significativa para todo o desenvolvimento da política local de mudanças climáticas.

Outra importante iniciativa no campo das mudanças climáticas foi implementada também no primeiro ano de mandato de José Serra. Em 6 de junho de 2005, foi instalado o Comitê Municipal sobre Mudanças Climáticas e Ecoeconomia Sustentável (CMMCE) por meio do Decreto Municipal 45.959, cujo objetivo era promover e estimular iniciativas orientadas em prol da mitigação das emissões de GEEs. Segundo Furriela (2011), “(...) o Comitê foi instituído por vontade política da Prefeitura, e, mais especificamente, pela ação política e pressão do Secretário do Verde e do Meio Ambiente, Eduardo Jorge” (p. 283).

No início, a coordenação dos trabalhos do Comitê ficou sob a responsabilidade da SVMA, sendo Eduardo Jorge seu presidente, com a composição desse fórum contando com mais sete secretarias municipais e duas autarquias ${ }^{4}$. Em termos teóricos, o Comitê pode ser interpretado como um fórum central da construção da política climática - e é assim que ele está caracterizado na linha do tempo destacada no início deste capítulo - por ser um ambiente em que diferentes atores e instituições se reuniam e debatiam. Ainda assim, o papel do Comitê foi estratégico do ponto de vista de legitimar o campo das mudanças climáticas dentro da estrutura institucional e organizacional da Prefeitura, além de representar um ambiente em que políticas eram criadas e implementadas. Embora apenas consultivo, sem poder deliberativo nenhum, a revisão da literatura e as entrevistas realizadas reafirmam a relevância do Comitê. Nessa perspectiva, o Comitê também pode ser interpretado como um importante instrumento da ação pública paulistana na agenda climática.

Furriela (2011), ao analisar o momento em que o Comitê emerge, considera o movimento, presente em diferentes lugares do mundo, de autoafirmação dos governos locais enquanto players relevantes na agenda climática:

"Percebe-se também que o Comitê resulta da integração de São Paulo a um movimento internacional de reação de governos locais que entendem não precisar esperar o comando de leis federais ou estaduais, nem tampouco as decisões da ONU, para agirem em prol do equilíbrio climática do planeta" (p. 315).

\footnotetext{
${ }^{4}$ Secretarias Municipais de Coordenação das Subprefeituras, de Infraestrutura Urbana e Obras, de Transportes, de Serviços, do Verde e Meio Ambiente, de Habitação, da Saúde, de Gestão, Empresa Municipal de Urbanização e Companhia Metropolitana de Habitação de São Paulo.
} 
Nesse sentido, o Comitê também pode ser entendido como um instrumento político estratégico utilizado pelo governo municipal para se posicionar de maneira protagonista e autônoma no cenário nacional, reivindicando um campo de atuação e competência.

Ainda que o CMMCE não contasse com a participação social direta, esse fórum pode ser considerado um importante instrumento de articulação horizontal entre os diferentes órgãos e atores políticos, tendo em vista que a coordenação dos trabalhos ficou sob responsabilidade da SVMA. Portanto, mais do que um fórum consultivo, a observação do histórico dos trabalhos do Comitê permite identificá-lo como um instrumento relevante de legitimação da agenda climática na estrutura administrativa da gestão municipal de São Paulo.

Conforme Lascoumes e Le Galès (2012) apontam, instrumentos desse tipo têm uma função dupla de envolver mais vozes na construção de políticas públicas, ao mesmo tempo que os mesmos atores sofrem um tipo de pressão para adequar sua atuação: "O objetivo perseguido é duplo: de uma parte, assegurar uma informação ao público sobre situações de risco; de outra parte, exercer uma pressão normativa sobre o emissor, estimulando-o a melhor enquadrar suas práticas" (LASCOUMES E LE GALÈS, 2012, p. 29).

A análise da composição do Comitê e dos trabalhos desenvolvidos a partir de sua estrutura permite observar um dos efeitos previstos para os instrumentos de ação pública destacado por Lascoumes e Simard (2008): a criação de "espaços agregadores" que promovem encontros de atores heterogêneos.

"Tout d'abord, l'instrument crée des effets d'agrégation. Il constitue un point de passage obligé et participe à ce que $M$. Callon a nommé les activités de traduction qui permettent à des acteurs hétérogènes de se retrouver sur des questions qu'ils acceptent de travailler en commun dans un réseau." (Lascoumes e Simard, 2011, p. 19).

O próprio nome do Comitê ("Ecoeconomia") e o conteúdo do decreto que o cria possibilitam interpretar a visão predominante naquela época a respeito da agenda climática e as oportunidades que poderiam emergir nesse contexto.

"CONSIDERANDO que as informações e propostas consolidadas pela Conferência das Partes da Convenção-Quadro das Nações Unidas Sobre Mudanças do Clima e pelo Protocolo de Kyoto deverão ser divulgadas, bem como estimulados os projetos voltados à utilização do Mecanismo de Desenvolvimento Limpo MDL, no Município de São Paulo." (Decreto No 45.959/2005). 
Vale lembrar que o Protocolo de Kyoto, assinado em 1997, entrou em vigência exatamente no ano de 2005. Diferentes olhares o interpretavam e mais especificamente o MDL como uma oportunidade de aferir ganhos financeiros para seus caixas e orçamentos. Essa leitura específica do discurso a partir do qual o Comitê foi criado permite identificar um olhar possivelmente mais econômico do que ligado aos valores desse compromisso, ao menos nesse momento inicial da gestão.

O segundo aspecto do governo Serra que merece destaque é o inventário de emissões. Em julho de 2005 foi publicado o $1^{\circ}$ inventário de emissões de GEEs do município de São Paulo. O documento teve como base as emissões do ano de 2003 e entre seus principais resultados está a indicação de que o setor de transportes era a principal fonte emissora de GEEs, sendo o setor de resíduos sólidos o segundo mais relevante. De maneira geral, é possível verificar que ambos os setores seriam objeto de intervenções da gestão municipal, desde o aproveitamento energético de aterros sanitários até a implantação da inspeção veicular e demais intervenções no setor de transporte/mobilidade.

Outro importante acontecimento ainda no primeiro ano de mandato de Serra foi o Programa Ambientes Verdes e Saudáveis (PAVs), criado a partir de uma articulação horizontal intersetorial entre a SVMA, a Secretaria de Saúde (SS) e a Secretaria de Assistência e Desenvolvimento Social (SADS) com apoio do Ministério da Saúde e do Programa das Nações Unidas para o Meio Ambiente (Pnuma). O objetivo do Programa foi oferecer formação na temática ambiental aos agentes comunitários ligados ao Programa Saúde da Família (PSF) e ao Programa Ação Social. O PAVs existe até os dias de hoje e, ao longo dos anos, os eixos temáticos das capacitações foram lixo, água, energia, biodiversidade, convivência saudável com animais e zoonoses, consumo consciente, cultura de paz e não violência.

Nota-se que o PAVs foi uma frutífera aproximação entre os campos da saúde e do meio ambiente, o que guarda semelhanças com a recente conexão, na trajetória profissional do secretário do Verde e Meio Ambiente, Eduardo Jorge, que foi um dos grandes idealizadores do programa. Para além dos campos temáticos, o PAVs demonstrou a possibilidade de diferentes secretarias no âmbito da prefeitura realizarem trabalhos em conjunto, algo que viria a se tornar cada vez mais comum ao longo da atual gestão. Outra característica interessante de se ressaltar em relação ao programa é a sua relação com a agenda climática, ainda que, a princípio, ao se observar o nome do programa, não haja nenhuma conexão direta ou óbvia com essa questão. De todo modo, ao se 
analisar os temas trabalhados na formação dos agentes de saúde, nota-se que as questões relacionadas ao clima estavam contempladas, como energia e água.

No plano internacional igualmente destaca-se, em 2005, a criação do C40, articulação internacional entre as maiores cidades do mundo com o objetivo de endereçar os desafios postos pelas mudanças climáticas. A cidade de São Paulo aderiu ao C40 desde seus primórdios, o que representa um fato relevante do ponto de vista da percepção dos líderes locais em relação a uma rede internacional específica para as questões climáticas. A adesão de São Paulo a essa articulação é também representativa em razão de a cidade ter sido a única da América Latina a compor o quadro de cidades do C40, situação que se manteria até 2008, o que também indica um diferencial e uma busca por certo protagonismo. Essa estratégia aparentava não ser difícil emplacar, dada a aparente falta de interesse dos demais governos, das diferentes instâncias, em ocupar uma posição de relevância no âmbito das políticas de mudanças climáticas.

A análise dos fatos que transcorreram ao longo do período considerado nesta dissertação permitirá observar, nesse sentido, a relevância e o lugar que o C40 ocupou no processo de construção da política climática paulistana.

Do ponto de vista da relação entre o governo municipal e o governo estadual de São Paulo, também é possível identificar a maneira como a agenda climática foi sendo incorporada. Desde o início é importante lembrar o leitor de que, em ambos os níveis, a liderança política era exercida pelo mesmo grupo, o Partido da Social Democracia Brasileira (PSDB). Enquanto Serra estava em seu primeiro ano de mandato enquanto prefeito, Geraldo Alckmin era o governador do estado desde 2001, quando assumiu o cargo após a morte de Mário Covas, e se manteve em 2003, após vencer as eleições.

Em 2005 os governos municipal e estadual estavam negociando as compensações ambientais vinculadas às obras, lideradas pelo governo do estado, do trecho sul do Rodoanel, anel rodoviário que circunda a região central de São Paulo. Dado que se tratava de uma questão ambiental, as tratativas se deram entre a Secretaria Municipal do Verde e Meio Ambiente, com Eduardo Jorge à frente, e a Secretaria Estadual de Meio Ambiente, chefiada por José Goldemberg, importante liderança no campo político e acadêmico brasileiro em questões relacionadas ao meio ambiente e à energia. Desta feita, Eduardo Jorge, representando a prefeitura, negociou para que as compensações, que foram aceitas e implementadas, fossem a criação de quatro parques nas áreas 
dos mananciais da Billings e Guarapiranga e uma estrada-parque, com faixa de até 300 metros, que ligasse as unidades de conservação daqueles locais.

O que se pode inferir a partir desse resgate histórico é que, de certo modo, a rede política partidária comum entre os mandatários dos governos municipal e estadual colaborou para que determinadas iniciativas vingassem, como as negociações a respeito das compensações ambientais. O que resultou dessa articulação foi uma importante política em termos de adaptação às mudanças climáticas, aumentando a cobertura verde da cidade e melhorando as condições dos corpos hídricos. Assim, uma das estratégias de adaptação às mudanças climáticas foi o aumento das áreas verdes da cidade, com vistas a aumentar a área de infiltração e a combater as enchentes e a formação de ilhas de calor.

A vitória de Serra nas eleições de 2004 contra Marta tem uma representatividade políticopartidária que não pode ser desconsiderada. Trata-se de políticos de grupos políticos que historicamente se contrapõem no cenário nacional, o que fornece um indicativo relevante na análise das políticas públicas.

Em sua dissertação na Universidade Federal de São Carlos (UFScar), Back (2012) interpreta o ano de 2005 como "uma mudança de gestão governamental (ciclo político) no município" que "abriu uma oportunidade (policy window) de mudanças e inserção de problemas na agenda governamental" (p. 131). Há certa dose de acurácia nessa interpretação, uma vez que, conforme ficou demonstrado nessa seção desse capítulo da presente dissertação, as mudanças climáticas ganham força no contexto político paulistano tanto do ponto de vista do discurso quanto do ponto de vista de políticas e ações empíricas. No campo da cognição, é possível identificar que os valores que consubstanciam a agenda climática começam a ser defendidos e compartilhados por um conjunto maior de atores, o que permite o avanço de redes dedicadas às questões climáticas, como o C40, a criação de fóruns, a exemplo do Comitê Municipal, e a implementações de ações que, independentemente de serem lideradas pela SVMA, foram atreladas às preocupações do aquecimento global, vide o PAVs.

Quadro 5. Tabela com a ideia, os atores, os instrumentos, as redes, o fórum e as ações do governo José Serra (2005-2006) 


\begin{tabular}{|c|l|}
\hline \multirow{2}{*}{ Instrumentos } & Eduardo Jorge \\
\cline { 2 - 2 } & José Goldemberg \\
\cline { 2 - 2 } & Inventário de emissões \\
\cline { 2 - 2 } & Comitê municipal (político) \\
\hline \multirow{2}{*}{ Redes } & Comitê municipal (de participação) \\
\hline Fórum & Comitê (espaço de troca) \\
\hline \multirow{3}{*}{ Ações } & PAVs \\
\cline { 2 - 2 } & Parques na Billings e Guarapiranga \\
\cline { 2 - 2 } & Estrada-parque \\
\hline
\end{tabular}

Fonte: Elaboração do próprio autor.

O fortalecimento da agenda climática dentro do governo municipal e a estratégia de vincular essa bandeira com determinadas ações de outras secretarias para além da SVMA, contaram com a liderança de Eduardo Jorge. Back (2012) também identifica esse papel desempenhado pelo então secretário municipal: “A formulação e implementação das políticas com interface no enfrentamento às mudanças climáticas foi realizada sob a coordenação e liderança do Secretário do Verde e Meio Ambiente, Sr. Eduardo Jorge, desde a gestão Serra” (p. 131). Ao decorrer da descrição e análise do caso que está sendo estudado será possível observar como essa liderança se desenvolveu ao longo dos anos e a sua relevância para o desenvolvimento da política climática paulistana.

Ainda que se possa reconhecer o fortalecimento em grande escala das mudanças climáticas com o início do governo Serra, é preciso ponderar que, em certa medida, existe certa continuidade de determinadas ações e estratégias que haviam sido iniciadas na gestão anterior.

Considerando esses elementos que representam a continuidade, é possível identificar limitações na análise desenvolvida por Back em 2012. O cientista político da UFScar tem como referencial teórico o americano John Kingdon e a sua obra "Agendas, Alternatives, and Public Policies", publicado em 1984 e já referenciado no capítulo teórico da presente dissertação quando foi abordada a figura do "empreendedor de políticas públicas”. Back desenvolve uma análise muito qualificada das gestões de 2003 a 2009, sendo muito fidedigno aos conceitos e definições de Kingdon, o qual tem como preocupação principal compreender como determinadas questões são reconhecidas como problemas e estes entram ou saem da agenda das políticas públicas. É exatamente por causa dessa relação estreita com o teórico americano que é possível reconhecer algumas limitações na leitura de Back sobre a realidade paulistana. 
Como foi exposto no capítulo teórico desta dissertação, as teorias de políticas públicas representam um importante aporte ferramental para desenvolver as análises. Não obstante, a tentativa destas em criar definições e enquadramentos para um mundo real que é cada vez mais dinâmico, onde as relações sociais envolvem uma infinidade de dimensões, expõe a necessidade primordial de saber utilizar essa caixa de ferramenta. Vale dizer que as teorias devem ser usadas para facilitar a compreensão de fenômenos sociais, e não o contrário, ou seja, tentar limitar os fenômenos às "caixas" criadas pelas teorias.

Nesse sentido, a primeira crítica ao aporte de Kingdon é sua concordância com a ideia de ciclos de políticas públicas, ainda que ele reconheça que isso significa uma drástica simplificação (Kingdon, 1984, p. 3). Possivelmente em razão desse elemento, Back interpretou a gestão Serra como um ciclo político completamente novo em relação ao governo Marta, não reconhecendo determinados elementos que representaram uma continuidade na agenda climática que estava sendo construída. O autor desta presente dissertação, considerando o ferramental teórico selecionado, considera que o conceito de ciclo de políticas públicas, com etapas e sequências muito bem definidas, não permite uma leitura adequada da realidade. A construção de políticas públicas é um processo muito mais caótico do que essas etapas.

A segunda crítica à construção teórica de Kingdon é trabalhar com o conceito de "ideia", sem considerar necessariamente os aspectos cognitivos na ação pública. Nesse sentido, nota-se na análise de Back a ausência de considerações a respeito dessa dimensão, sem incorporar os valores e aspectos mais subjetivos relacionados à mudança climática, o que certamente teria fortalecido sua importante contribuição acadêmica.

Por fim, em abril de 2006, o prefeito José Serra, após 15 meses àfrente do governo, deixou o cargo para se candidatar a governador do estado de São Paulo. A respeito desse movimento político e da figura de José Serra, chama a atenção o comentário de Eduardo Jorge no livro "Três ou quatro sementes de araçá" (2013): "Sua fraqueza é o descuido com uma construção partidária, é sua descrença na democracia
participativa como enriquecedora da democracia representativa. Sua fraqueza maior é a
obsessão em ser presidente da república. Fui contra sua saída para ser candidato a
governador. O único secretário a falar isto publicamente" (p. 18).

Por causa desse cenário, seu vice, Gilberto Kassab (PFL), assumiu a Prefeitura de São Paulo. 
2.4.Gestão do prefeito Gilberto Kassab (PFL/DEM/PSD) (2006-2012)

Kassab assume a prefeitura de São Paulo após uma trajetória político-partidária vinculada ao Partido Liberal (PL), quando se elegeu vereador, e desde 1995 é filiado ao Partido da Frente Liberal (PFL), pelo qual se elegeu deputado estadual. De 1997 a 1998 foi secretário de Planejamento do prefeito Celso Pitta (PPB) e em 1999 e 2003 venceu as eleições para deputado federal também pelo PFL. Essa trajetória permite identificar um posicionamento de Kassab mais à direita no espectro político.

Mais uma vez, a análise compartilhada por Eduardo Jorge no livro "Três ou quatro sementes de araçá" (2013) contribui para compreender o contexto político do governo municipal naquele momento de transição e, por óbvio, especialmente a relação do líder da pasta ambiental com o novo prefeito:

\footnotetext{
“Gilberto Kassab. Não tinha proximidade política ou pessoal com ele. Ao contrário de Serra, de tradição mais à esquerda, ele vinha de área conservadora e não tinha experiência administrativa consistente. Um dilema para mim, um socialista e ecologista do PV que aceitara participar de um governo social democrata com promessa de abertura para o desenvolvimento sustentável" (p. 18).
}

Engenheiro civil formado pela Poli/USP e economista pela FEA/USP, Kassab compôs a chapa com José Serra nas eleições de outubro de 2004, após acordo entre seus respectivos partidos, o PFL e o PSDB. Com a saída do tucano, tornou-se em 2006 o $50^{\circ}$ prefeito da cidade de São Paulo. De maneira geral, Kassab manteve a equipe da Prefeitura e deu prosseguimento as ações que já estavam sendo desenvolvidas anteriormente.

\subsubsection{Os dois primeiros anos da gestão Kassab: Ações concretas na agenda climática}

Fora do contexto local, o ano de 2006 foi de grande relevância para a agenda climática no contexto internacional a partir da divulgação do relatório Stern. O documento fora encomendado pelo governo do Reino Unido ao economista de mesma nacionalidade, Nicholas Stern. Uma das principais conclusões que o documento aponta é que os investimentos necessários para combater as mudanças climáticas seriam muito maiores caso nada fosse feito e, a médio e longo prazo, os governos teriam que enfrentar então as consequências da ausência de ação. 
O relatório Stern representa mais um fator relevante do contexto internacional para o avanço das políticas climáticas, podendo ser interpretado como um instrumento de ordem informativa para a ação pública nesse campo. Para a realidade paulistana, ainda que tenha sido identificada uma relação direta entre o relatório e as políticas públicas locais, pode-se dizer que, do ponto de vista do avanço das ideias, da compreensão dos atores políticos e sociais sobre o tema, esse instrumento desempenhou um papel importante.

Ainda no contexto internacional, o ano de 2007 foi igualmente um momento importante para o campo das mudanças climáticas, quando o IPCC, considerado nessa dissertação como principal rede epistêmica do campo, divulgou seu $4^{\circ}$ Assessment Report (AR4). Como o jornalista científico Claudio Angelo explica em sua obra "Espiral da morte" (2016):

\begin{abstract}
"O documento, divulgado em fevereiro de 2007, em Paris, trazia o alerta mais poderoso já feito sobre o presente e o futuro do clima da Terra. Ele dizia que o aquecimento do sistema climático era 'inequívoco' e que a parte dele era 'muito provavelmente' devida a atividades humanas. No palavreado estatístico do painel do clima, 'muito provavelmente' denota uma chance de mais de $90 \%$ " (p. 46).
\end{abstract}

Três meses depois de divulgado o relatório da única rede epistêmica climática internacional aconteceria na cidade de Nova York, em maio de 2007, o 2nd Large Cities Climate Summit, o $2^{\circ}$ encontro do C40, rede de grandes cidades conectadas a partir da agenda climática. Desde que São Paulo passou a integrar o C40 em 2005, esta seria a primeira participação da cidade nesse fórum promovido pela rede $\mathrm{C} 40$.

Na ocasião, a cidade paulista já tinha algumas ações concretas nessa agenda que poderia apresentar às demais cidades integrantes da rede. Entre elas, destacam-se a publicação do inventário de emissões de gases de efeito estufa e a instalação do Comitê Municipal, ambos em 2005.

Segundo Furriela (2011) e Back (2012), a participação de Kassab no C40 foi importante para que o prefeito tivesse contato com importantes movimentos políticos relacionados à agenda das mudanças climáticas, como o prefeito de Nova York, Michael Bloomberg. Assim, a participação da cidade de São Paulo nesse fórum internacional foi essencial para fortalecer o engajamento de Kassab nessa questão e dar apoio às ações coordenadas pela SVMA. 
Para além da inserção em uma rede política internacional em mudanças climáticas, o que mais chamou atenção na participação de São Paulo nesse encontro do C40 foi o discurso do prefeito Kassab. Na ocasião, Kassab, agora no partido Democratas (DEM), após a extinção do antigo PFL, assumiu publicamente o compromisso de aprovar uma política pública de combate às mudanças climáticas.

O discurso de Kassab pode ser interpretado como um instrumento normativo, uma vez que emitia um sinal claro do posicionamento do chefe do governo paulistano, indicando a possibilidade de que avanços concretos fossem efetivados. Naquele mesmo momento, mais especificamente dois meses antes do encontro em Nova York, o Centro de Estudos em Sustentabilidade da FGV havia sido contratado pela Prefeitura de São Paulo para realizar estudos técnicos para formulação do anteprojeto de lei de uma política municipal de mudanças climáticas, tendo o apoio da SVMA, do ICLEI e suporte financeiro do Pnuma.

Mais uma vez é possível identificar a aproximação de diferentes atores/instituições com o objetivo de fortalecer a construção da política climática paulistana: o ICLEI, uma rede internacional, e a SVMA, um órgão do governo, em uma parceria que vinha sendo construída desde 2003. Junto deles, uma universidade de renome, a Fundação Getúlio Vargas, que foi, mais especificamente, seu braço para questões relacionadas à sustentabilidade e, por fim, a Organização das Nações Unidas, um braço da também dedicado à agenda ambiental.

Identifica-se, portanto, um instrumento de ordem informativo e, em parte, normativo, primordial para o avanço das políticas públicas de mudanças climáticas. Não há dúvidas de que esse documento do IPCC exerceu influência nos diferentes níveis de governo no Brasil. É importante pontuar ao leitor que naquela época o país vivia um momento político, no cenário nacional, de reeleição do presidente Lula (PT), de fortalecimento de seu partido e de crescimento econômico da ordem de 6,1\%, o maior desde 1986.

Ainda no campo internacional um terceiro acontecimento em 2007 merece ser destacado: a realização da $13^{\text {a }}$ Conferência das Partes no âmbito da UNFCCC, realizada em dezembro daquele ano em Bali, Indonésia. Do ponto de vista da agenda climática internacional, a COP, como já dito, representa o principal fórum de caráter político da agenda climática. Contudo, as pesquisas realizadas no âmbito desta dissertação não identificaram uma relação direta entre a COP 13 e o contexto climático paulistano. De todo modo, o principal destaque dessa edição da COP é 
exatamente uma das respostas que emergiram a partir do encontro: o Local Government Climate Roadmap, que foi uma coalizão criada como resposta ao Bali Action Plan, o acordo final dos governos nacionais no âmbito da COP. Essa articulação tem uma relevância importante para o estudo de caso de São Paulo porque representa um fortalecimento do discurso e do posicionamento dos governos locais, os quais assumem uma função protagonista nas políticas climáticas. Vale destacar que o ICLEI desempenhou um papel relevante nesse processo internacional, ao mesmo tempo que também participava de maneira ativa na construção da política climática do município de São Paulo.

No contexto do estado de São Paulo, o ex-prefeito Serra venceu as eleições de outubro de 2006 contra Aloizio Mercadante (PT) - mais um embate direto entre PSDB e PT em território paulista -, assumindo o cargo de governador em 2007. Do ponto de vista político, isso representava uma oportunidade de cooperação entre os governos estaduais e municipais em um amplo conjunto de áreas.

Um dos exemplos que concretizou essa oportunidade foi a Operação Defesa das Águas, criada em março de 2007 a partir da cooperação entre o governo estadual e a Prefeitura de São Paulo. A iniciativa tinha como objetivo preservar e recuperar as áreas de mananciais e envolvia diferentes órgãos de governo e empresas como a Sabesp, visando, sobretudo, implementar medidas de controle de ocupação irregular. À época, o Secretário Estadual de Meio Ambiente era Xico Graziano, quadro do PSDB, tendo já exercido o cargo de presidente do INCRA, em 1995, durante o governo FHC, de Secretário Estadual de Agricultura (1996-1998) na gestão Mário Covas e de deputado estadual (1998-2006).

Um ano depois de criada a iniciativa, Eduardo Jorge, em entrevista ao Pnuma relatada no livro "Três ou quatro sementes de araçá" (2013), relata os avanços dela:

\footnotetext{
Os resultados são visíveis: ocupações irregulares foram e são diariamente demolidas e a população, aos poucos, vai se conscientizando e denunciando vendedores de lotes ilegais. (...) Tudo isso graças à ação da fiscalização integrada dos órgãos da prefeitura e do governo do estado, com comitês constituídos em cada Subprefeitura. (ALVES SOBRINHO, 2013, p. 25).
}

Ainda na mesma entrevista, Jorge continua a avaliar algumas políticas públicas implementadas de forma integrada com o governo estadual. Entre as destacadas pelo então secretário destaca-se a criação de parques lineares: 


\begin{abstract}
"Atualmente estão em implantação 27 parques lineares, distribuídos por diferentes regiões da cidade. Além de preservarem as várzeas dos cursos d'água de invasões, mantêm as áreas do entorno dos córregos permeáveis, ajudando a escoar água e evitar enchentes" (idem, p. 26).
\end{abstract}

Nota-se, portanto, que a agenda das águas e das florestas teve avanços importantes nesse período, compreendidos não somente enquanto políticas ambientais ou de qualquer outra esfera, mas principalmente enquanto política de adaptação no contexto urbano. Nesse caso, observa-se uma articulação relevante tanto entre secretarias e órgãos de um mesmo governo quanto um trabalho em conjunto entre níveis diferentes de governo. No âmbito estadual estavam envolvidas as Secretarias do Meio Ambiente, Saneamento e Energia/Sabesp/EMAE, Habitação/CDHU e Segurança Pública, enquanto no governo municipal participavam da Operação Defesa das Águas as Subprefeituras, as Secretarias de Segurança Urbana, do Verde e Meio Ambiente, da Habitação e do Governo. Mais uma vez, o protagonismo e o entusiasmo de Eduardo Jorge em uma iniciativa vinculada à agenda climática ficavam visíveis.

Internamente, na Prefeitura de São Paulo, a partir de uma articulação entre a SVMA e a Secretaria Municipal de Educação, foi criado em 2007 o Programa Difusão da Carta da Terra na rede municipal de ensino ("Carta da Terra em Ação"), tendo como objetivo divulgar e desenvolver ações educativas com base nos princípios, valores e conteúdo desse documento da comunidade global. A Carta da Terra é um documento resultante de anos de negociação no âmbito da sociedade civil global e que traz consigo uma declaração sobre os princípios da paz, da justiça socioeconômica e da sustentabilidade.

Destaca-se que os princípios basilares desse documento guardam uma conexão estreita com as questões climáticas contemporâneas, como o impacto das ações do homem na Terra e a necessidade de construir um novo paradigma de desenvolvimento de baixo carbono. A iniciativa foi fruto de uma articulação entre Eduardo Jorge (SVMA) e Alexandre Schneider, Secretário de Educação. Entre seus resultados, ressalta-se a inserção do documento da Carta da Terra em 30 turmas descentralizadas nas diversas regiões da cidade, alcançando cerca de 800 escolas. Foram reproduzidos 65 mil exemplares do documento, distribuídos a todos os professores da rede municipal.

O programa de difusão da Carta da Terra se estabeleceu a partir da Universidade Aberta do Meio Ambiente e da Cultura de Paz (UMAPAZ), criada em 2005, com o objetivo de oferecer programas e atividades de educação ambiental. Assim, a incorporação da Carta da Terra nas 
escolas é relevante para a agenda climática, uma vez que esse documento, publicado em 2000, está diretamente relacionado aos impactos na biosfera e nos ecossistemas da Terra causados pela ação do homem, especialmente as mudanças climáticas. Nesse sentido, ao passo que o Programa de Difusão da Carta da Terra pode ser considerado uma ação significativa da prefeitura de São Paulo, a Carta da Terra em si mesma representa um importante instrumento comunicacional da ação pública no campo das mudanças climáticas. Assim sendo, destaca-se o objetivo do programa de difusão de promover uma maior conscientização nas crianças e jovens paulistanos sobre a necessidade de refletir sobre os impactos das atividades humanas no meio ambiente.

Outra ação desenvolvida no âmbito da Prefeitura de São Paulo em 2007, no segundo ano de gestão do prefeito Kassab, se deu no campo da eficiência energética e das fontes renováveis de geração de energia, a partir de uma articulação da pasta ambiental com a de construção civil. Em julho de 2007 foi publicada a Lei Municipal no 14.459, instituindo a chamada "Lei Solar". A lei alterou um dispositivo do Código de Obras e Edificações do município de 1992, estabelecendo que novas construções com determinadas características eram obrigadas a dispor de sistema de aquecimento solar de água. As negociações para a construção dessa lei envolveram uma gama diversificada de atores, entre eles o Sinduscon-SP (Sindicato da Indústria da Construção Civil do Estado de São Paulo), a Abrava (Associação de Fabricantes de Equipamentos de Refrigeração e Aquecedores Solares), o Greenpeace, os Amigos da Terra e a WWF.

A Lei Solar merece destaque no processo de construção da política climática paulistana, uma vez que propõe uma inovação relevante, incorporando o campo da geração de energia e o da construção civil a uma agenda considerada majoritariamente ambiental. Outro elemento que aumenta ainda mais a relevância dessa iniciativa é o protagonismo desta, pois a partir da Lei Solar São Paulo se tornou a primeira cidade do Brasil a aprovar uma lei que obrigava todos os prédios novos a usar $40 \%$ da água aquecida por meio da energia solar.

Os dois anos de gestão do prefeito Kassab, em 2006 e 2007, podem ser interpretados de maneira positiva em relação ao desenvolvimento e à construção de uma política de mudanças climáticas na capital paulista. Nesse contexto, é importante considerar que, do ponto de vista político-eleitoral, Kassab enfrentava um contexto de necessidade de se posicionar e de se fortalecer politicamente, conquistando uma independência em relação à figura de José Serra, de modo a se habilitar para disputar as eleições municipais de outubro de 2008, que se aproximavam. 
Assim sendo, é possível interpretar que a agenda climática representou uma oportunidade para o prefeito se fortalecer. No âmbito internacional, o prefeito Kassab ocupou o espaço do C40, aproveitando a oportunidade para ganhar destaque e fortalecer a sua imagem a partir de um discurso positivo sobre a agenda climática. Em termos de articulações com outras instâncias de governo, a Prefeitura também logrou avanços a partir da parceria estabelecida com o governo estadual no âmbito da Operação Defesa das Águas para a proteção dos mananciais da cidade, valendo-se da relação próxima entre o prefeito Kassab e o governador Serra. O programa de difusão da Carta da Terra na rede municipal de ensino apresentou uma característica que marcou a gestão Kassab, com a SVMA desenvolvendo a agenda climática a partir de parceiras com outras secretarias e outros setores. No caso da Carta da Terra, a parceria foi realizada com a pasta da educação, enquanto o avanço da Lei Solar, obrigando a instalação de equipamentos de aquecimento solar em edifícios, foi possível a partir de uma aproximação com setor da construção civil.

\subsubsection{8: ano eleitoral e avanços na construção da política climática local}

Mais iniciativas práticas relacionadas ao enfrentamento das mudanças climáticas foram implementadas na cidade de São Paulo durante os demais anos da gestão Kassab. No ano de 2008, em especial, uma quantidade significativa de ações na agenda climática tornou-se realidade. Aquele ano representava um período eleitoral crucial, no qual o prefeito precisaria mostrar resultados à população, de modo a possibilitar sua vitória no pleito em outubro, agora na figura de cabeça de chapa. Em relação ao processo de construção de uma política municipal de mudanças climáticas, além das ações que já vinham sendo implementadas, o ano de 2008 seria central, uma vez que o poder executivo daria o primeiro passo para institucionalizar essa política no âmbito do arranjo local.

Em janeiro de 2008 entrou em operação o aproveitamento energético a partir do gás metano emitido no Aterro São João, localizado no bairro de São Mateus, na zona leste da cidade. Esta seria a segunda experiência da cidade de São Paulo com esse tipo de atividade, pois a primeira havia iniciada em 2004, no último ano da gestão da ex-prefeita Marta Suplicy.

A geração de biogás a partir dos resíduos representou mais um exemplo de ação de vanguarda do município de São Paulo em termos de política de mitigação de geração de gases de 
efeito estufa. A Unidade Térmica de Energia do Aterro São João representava a segunda experiência desse tipo em todo o Brasil, sendo a segunda também em território paulistano.

Em relação a esse tipo de prática, é importante destacar como as duas gestões - de Marta Suplicy e Gilberto Kassab -, em termos político-partidários, representavam direções opostas, mas em termos de avanços na agenda climática apontavam para a mesma direção.

Do ponto de vista do discurso e do convencimento político e social, é possível compreender como essas experiências lograram avanços de maneira tão rápida. A questão econômica e a possibilidade de a Prefeitura aferir ganhos financeiros a partir da venda de créditos de carbono no mercado internacional, sem dúvidas, representou uma variável central para essas ações nos aterros de Bandeirantes e São João. Em setembro de 2007 a Prefeitura arrecadou R\$ 34 milhões com a venda de créditos de carbono provenientes do aterro Bandeirantes e, em setembro de 2008, a partir de um segundo leilão, arrecadou R\$ 37 milhões com créditos de carbono dos dois aterros.

Historicamente, a variável econômico-orçamentária de uma gestão pública gera impactos significativos na opinião pública. Considerando isso, é relevante notar que o segundo leilão foi realizado durante o período eleitoral de 2008, um mês antes da votação efetivamente acontecer. Isso demonstra uma habilidade do então prefeito Kassab, que disputaria a reeleição, em utilizar a agenda climática a seu favor, uma vez que venceria o pleito.

Outra importante iniciativa no âmbito do "guarda-chuva" climático da gestão municipal paulistana foi o "Programa de Inspeção e Manutenção de Veículos em Uso". Em teoria, o programa existia no regramento municipal desde 1995, mas nunca havia sido regulamentado e implementado de fato. Em abril de 2008 a Prefeitura sancionou a Lei n. 14.717 e, no mesmo mês, a regulamentou a partir do Decreto n. 49.463, dando orientações específicas para que, finalmente, a inspeção veicular se tornasse realidade na cidade de São Paulo.

O objetivo do programa foi acompanhar de maneira regular as condições das emissões de gases dos veículos em relação às regras técnicas estabelecidas, determinando limites e impedindo a circulação de automóveis fora dos padrões. Tendo em vista que o inventário de emissões apontou o setor de transportes como principal emissor, essa política é considerada um dos principais componentes da estratégia municipal de mitigar suas emissões. 
A grande ideia motivadora dessa política pública é a preocupação com a saúde pública, conforme descrito nas primeiras linhas do decreto regulamentador: "CONSIDERANDO que a frota de veículos em uso é a principal fonte de poluição do ar e de poluição sonora no Município de São Paulo, e que essas formas de poluição contribuem para a deterioração das condições de saúde pública e da qualidade de vida da população" (Decreto No. 49.463, de 30 de abril de 2008). Um dos fatores que colaborou para que os atores políticos fossem convencidos da relação entre o setor de transporte e seus impactos na saúde pública foram os estudos técnicos do professor Paulo Saldiva, da Faculdade de Medicina da Universidade de São Paulo.

Resgatando o referencial teórico destacado nesta dissertação é possível interpretar o Programa de Inspeção Veicular sob duas óticas complementares. Em primeiro lugar, enquanto uma ação prática de extrema relevância para a construção da política climática paulistana, especialmente em termos de mitigação e controle de emissão de gases de efeito estufa. Adicionalmente, as diretrizes estabelecidas na legislação e as normas representam um importante instrumento normativo da ação pública climática, pois determinam um conjunto de práticas e regras que os cidadãos devem cumprir; caso contrário, estes ficam sujeitos a sanções do poder público.

É interessante notar que a ação implementada pelo governo Kassab em 2008 teve como base uma lei, ou seja, um instrumento legal existente no regramento jurídico paulistano desde 1995 e criado durante o governo do então prefeito Paulo Maluf (PPR). Conforme Lascoumes e Le Galès (2005) apontam, é bastante comum que instrumentos sejam implementados com um discurso novo, com uma roupagem nova, mas na verdade eles representam a releitura, ou renovação, de um instrumento antigo já existente. "Mais, bien souvent, le changement annoncé repose en grande partie sur des glissements, des reconversions-adaptations, des recyclages d'instruments déjà mis à l'épreuve" (LASCOUMES E LE GALÈS, 2005, p.359).

A implementação da inspeção veicular se deu de forma gradual. Em 2008 a inspeção foi destinada somente a veículos movidos a diesel. Em 2009 estendeu-se para toda a frota de motos e parte dos automóveis. Em 2010 o processo de implantação alcançou 100\% da frota. Como forma de impulsionar a adesão social ao programa, durante os dois primeiros anos de vigência foi adotado o reembolso da taxa de inspeção. 
O programa de inspeção veicular é, portanto, considerado aqui outro exemplo de política pública adotada na cidade de São Paulo que estabeleceu uma conexão direta entre a agenda climática e as questões de saúde pública, assim como o PAVs já havia feito em 2005. Conforme descrito mais à frente, demais iniciativas da gestão municipal se juntariam a esse discurso "mudanças climáticas - saúde pública", fortalecendo, assim, a leitura de que a saúde pública representou um dos dois pilares do discurso de sensibilização e convencimento em prol da agenda climática no município de São Paulo.

O setor de transportes, principal emissor de GEEs, como apontava o inventário publicado em 2005, contou com mais um avanço em termos de mitigação no ano de 2008 a partir da inauguração da ciclovia na Radial Leste, via que liga a zona leste ao centro da cidade. Intitulada ciclovia Caminho Verde, ela seria a primeira ciclovia de rua na capital do estado. Quando foi inaugurada estavam prontos $6 \mathrm{~km}$ de extensão, com um planejamento total de $12 \mathrm{~km}$, indo da estação de metrô Corinthians-Itaquera até a estação Tatuapé. Além da ciclovia, foram implantados bicicletários e pontos de aluguel em algumas estações de metrô, formulando, para além da agenda climática e de transportes, uma estratégia de mobilidade urbana.

Outra ação que foi integrada à estratégia de adaptação climática do município de São Paulo se estabeleceu a partir da criação de parques municipais, de modo a aumentar a cobertura florestal na capital. Um exemplo dessa política se deu com a criação do Parque Linear da Área de Proteção Ambiental (APA) do Tietê.

O Parque Linear do Tietê, nas margens do principal rio que corta a cidade, foi, naquela época, o maior parque desse tipo do mundo, com uma extensão do bairro paulistano de Ermelino Matarazzo até a cidade de Salesópolis. As obras de construção do parque foram retomadas em 2008 a partir da compensação ambiental exigida pelo município por causa das obras de extensão viária da Marginal Tietê. Entre as exigências colocadas pelo Departamento de Controle e Qualidade Ambiental (DECONT) da Prefeitura estava o plantio de 83 mil árvores e a construção da estrada-parque e da ciclovia de $14 \mathrm{~km}$ que comporiam o parque linear.

Ainda em 2008 mais um acontecimento político relacionado à construção da política municipal de mudanças climáticas em São Paulo merece destaque. Em agosto de 2008 o Poder Executivo enviou à Câmara Municipal o Projeto de Lei (PL) n. 530, propondo a instituição da Política de Mudança do Clima no Município de São Paulo. Esse documento que a Prefeitura 
apresentou à Câmara era resultado de um processo de construção coordenado pela SVMA, envolvendo a academia, na figura da FGV e seu Centro de Estudos em Sustentabilidade (GVces), com uma articulação entre a sociedade civil e as demais secretarias do Executivo. Grande parte das publicações acadêmicas que estudaram esse processo (FURRIELA, 2011; BACK, 2012; CORTESE, 2013) destaca que essa estratégia de construção representou um dos principais elementos para que o PL chegasse ao Legislativo com uma chancela e legitimidade grande, o que aumentaria suas chances de aprovação.

Entre as consideráveis inovações que o PL trazia consigo a principal delas foi o compromisso de redução em 30\% das emissões de GEEs até 2012, estabelecendo, assim, metas quantificáveis e com prazo delimitado. Na ocasião da apresentação do PL, Eduardo Jorge (SVMA) deu entrevista a Eduardo Geraque, da Folha de S. Paulo, comentando o estabelecimento de meta de redução de emissão: "Podemos dizer que é uma medida ousada [o estabelecimento de metas], mas totalmente factível".

Vale lembrar que, no contexto internacional daquele momento, o Estado brasileiro vinha se posicionando de maneira bastante tímida nas negociações climáticas. A última COP havia acontecido em dezembro de 2007, em Bali (Indonésia), e em 2009 aconteceria a famigerada COP 15 em Copenhague, na Dinamarca. Essa timidez da União vinha sendo observada pelo município de São Paulo, que vislumbrava uma importante oportunidade de protagonismo na agenda climática. Nessa mesma entrevista à Folha de S. Paulo, em 14 de agosto de 2008, Eduardo Jorge segue com sua reflexão acerca das políticas de mudanças climáticas no Brasil: "Defendemos as metas desde 2005. Essa posição brasileira está errada. Acaba servindo de álibi para a posição dos Estados Unidos e da China [países que também não aceitam metas]".

Ainda na mesma entrevista Eduardo Jorge afirmou que o art. 50 do PL 530 apresentado à Câmara Municipal era o mais importante do PL, ao prever a redução gradual do uso de combustíveis fósseis nos novos contratos municipais de transporte público:

"Os programas, contratos e autorizações municipais de transportes públicos devem
considerar redução progressiva do uso de combustíveis fósseis, ficando adotada meta
progressiva de redução de, pelo menos, $10 \%$ (dez por cento) a cada ano, a partir de 2008 ,
e a utilização, em 2017 , de combustível renovável não-fóssil por todos os ônibus do
sistema de transporte público do Município."

Vale lembrar que no período em que o PL fora apresentado Kassab já estava à frente da Prefeitura havia dois anos. Nesse tempo ele já apresentava um "acúmulo" de iniciativas 
relacionadas à agenda climática que aumentavam sua capacidade de convencer os atores políticos a votarem a favor do projeto de lei, que visava criar um arcabouço institucional para a política municipal de mudanças climáticas.

Assim sendo, o PL 530 pode ser interpretado como importante instrumento normativo para a construção e, especificamente, para a institucionalização da política climática paulistana. $\mathrm{O}$ projeto de lei emergiu em um contexto em que o município já vinha implementando um conjunto de iniciativas no âmbito do "guarda-chuva" climático e, sobretudo, propondo objetivos e metas claras para o desenvolvimento das ações públicas naquele campo.

Em outubro daquele mesmo ano ocorreriam as eleições municipais em todo o Brasil. Em São Paulo seria a primeira vez que Kassab disputaria as eleições enquanto cabeça de chapa, após um período de três anos comandando a capital paulista. Ele disputaria pelo partido político Democratas (DEM) após a mudança de nomenclatura do extinto PFL, em março de 2007. Kassab disputaria as eleições contra a ex-prefeita Marta Suplicy (PT), em uma coligação com os partidos PMDB, PR, PV, PSC e PRP. Em disputa no segundo turno, Kassab venceu as eleições contra a petista com $60,72 \%$ dos votos.

Kassab estava, portanto, habilitado para mais quatro anos de governo na cidade de São Paulo. Agora com mais força política ainda, após sair fortalecido e legitimado de uma disputa eleitoral em que ele era o principal nome e não mais a figura de vice. O prefeito viria a promover algumas mudanças nas secretarias que, em grande parte, ainda eram "herança" de José Serra. $\mathrm{Na}$ SVMA, Eduardo Jorge seguiria até o final do mandato. Os próximos quatro anos seriam centrais para a política climática paulistana, com um conjunto de atividades que já vinha sendo planejadas e implementadas e, em especial, com a tramitação do projeto de lei que institucionalizaria o arcabouço jurídico-legal dessa política.

2.4.3. A institucionalização da política climática paulistana a partir de uma lei específica (2009)

Após cerca de dez meses de tramitação do PL 530/08 na Câmara Municipal, em 5 de junho de 2009 foi instituída a Política Municipal de Mudança do Clima do Município de São Paulo (PMMC/SP) a partir da Lei n. 14.933. O tempo de tramitação no legislativo foi consideravelmente rápido e, ao final da votação, o placar final foi de aceitação unânime - 51 votos a favor e nenhum contra. A documentação e as publicações disponíveis não deixam claros os elementos que 
possibilitaram esse avanço, o que dá espaço para que novos inputs sejam incorporados na análise da presente dissertação a partir das entrevistas realizadas e a análise elaborada no capítulo 4 .

Vale destacar a temporalidade da instituição da PMMC/SP em relação às políticas de mudanças climáticas do estado de São Paulo e do Brasil. Conforme demonstrado no diagrama (Figura 15), a política paulistana foi criada em junho de 2009, enquanto a política estadual de São Paulo data de novembro (Lei Estadual n. 13.798) e a política nacional foi instituída em dezembro do mesmo ano (Lei Federal n. 12.187). Naquele ano, José Serra (PSDB) ocupava o cargo de governador de São Paulo e Luiz Inácio Lula da Silva (PT) era o presidente da República.

A respeito do posicionamento dos diferentes níveis de governo no âmbito do pacto federativo brasileiro, a análise do histórico dos acontecimentos permite observar alguns elementos que indicam uma ausência de um posicionamento "inovador" do Estado brasileiro na agenda climática, seja nas negociações internacionais, especialmente no âmbito das COPs, seja na construção de suas políticas internas. Essa ausência fora observada por alguns líderes políticos, o que fica demonstrado, por exemplo, no espaço que a cidade de São Paulo vinha ocupando em fóruns internacionais, a exemplo do C40 e a própria entrevista de Eduardo Jorge à Folha de $\mathrm{S}$. Paulo em agosto de 2008. Em outra ocasião, em setembro de 2008, em entrevista à jornalista Amália Safatle, para a Revista Página 22, ao responder à pergunta, "O que o senhor destacaria no projeto [de lei 530]?”, Eduardo Jorge aponta “A posição da cidade de São Paulo diverge da do governo nacional e diz: 'Nós vamos assumir metas, sim’ (...) É uma posição política, com repercussão nacional, e acho que até internacional”.

Nesse sentido, o fato de São Paulo instituir uma política específica para ações de mitigação da emissão de gases de efeito estufa e de adaptação ao aquecimento global em junho de 2009 colocava o município na vanguarda dessa agenda. A cidade de São Paulo seria a primeira cidade brasileira a ter uma lei de mudanças climáticas.

O poder econômico de São Paulo e seu contingente populacional são características que por si só já fazem da cidade um território importante dentro do contexto nacional. Além disso, historicamente a cidade traz consigo exemplos de pioneirismo e protagonismo político. Assim, a promulgação da PMMC/SP antes do posicionamento oficial do governo estadual de São Paulo e do governo federal garantiu ao município e aos seus respectivos atores uma relevância política substancial tanto na escala nacional quanto nos fóruns internacionais. 
Em relação ao conteúdo da Lei Municipal n. 14.933, de 5 de junho de 2009, alguns destaques merecem ser elencados. Em primeiro lugar, as diretrizes da Política (art. $3^{\circ}$ ) devem ser interpretadas como um importante reforço conceitual de que os governos locais, no geral, mas especialmente no arcabouço legal brasileiro, têm competências legais centrais para as políticas de mudanças climáticas. O protagonismo desse nível de governo deve ser, portanto, cada vez maior. As 15 diretrizes presentes na lei paulistana consideram a relação entre diversas competências municipais e ações de mitigação e adaptação, entre elas a promoção do uso de energias renováveis, o planejamento urbano, o parcelamento e uso do solo, as áreas verdes, o licenciamento ambiental, as compras públicas, os resíduos, o transporte público, a tributação e demais instrumentos econômicos.

Outro destaque da referida lei é a adoção de uma meta específica, com prazo determinado de cumprimento, algo que representava uma inovação de grande relevância, sobretudo porque as leis estadual e nacional não haviam incluído metas. $\mathrm{O}$ art. $5^{\circ}$ da Lei Municipal determinou que:

"Para a consecução do objetivo da política ora instituída, fica estabelecida para o ano de
2012 uma meta de redução de $30 \%$ (trinta por cento) das emissões antrópicas agregadas
oriundas do Município, expressas em dióxido de carbono equivalente, dos gases de efeito
estufa listados no Protocolo de Quioto (anexo A), em relação ao patamar expresso no
inventário realizado pela Prefeitura Municipal de São Paulo e concluído em 2005.
Parágrafo único. As metas dos períodos subseqüentes serão definidas por lei 2 (dois) anos
antes do final de cada período de compromisso."

A meta de redução de emissão foi considerada bastante ousada por muitos especialistas, o que não impediu a manutenção dela na redação final da lei. Vale dizer que outras metas também foram incluídas na lei de mudanças climáticas, apesar de não terem recebido tanto atenção, a princípio. Essas metas encontram-se nas disposições finais da lei de junho de 2009 e referem-se ao teor máximo de enxofre do óleo diesel com prazos para 2012 (art. 48), o programa obrigatório de coleta seletiva e instalação de ecopontos até 2011 (art. 49) e a redução progressiva do uso de combustíveis fósseis nos transportes públicos municipais, de modo que, em 2018, toda a frota de ônibus fosse movida a combustível "renovável não-fóssil" (art. 50).

De maneira geral, a lei foi estruturada com base em estratégias de mitigação e adaptação específicas para os setores de transportes, energia, gerenciamento de resíduos, saúde, construção civil e uso do solo, que fornecem indícios das ações que viriam a ser implementadas a partir daquele momento. 
Por fim, vale destacar a institucionalização de um conjunto de instrumentos para a implementação da política de mudanças climáticas. Entre eles estão os instrumentos de informação e gestão, com destaque para o inventário de emissões de gases de efeito estufa (que deve ser atualizado a cada cinco anos), os instrumentos de comando e controle, como o licenciamento ambiental, e os instrumentos econômicos, como os tributos cobrados pelo município e o próprio Mecanismo de Desenvolvimento Limpo (MDL) no âmbito internacional.

Nota-se, portanto, que a PMMC/SP representou um instrumento central da ação pública paulistana na agenda climática, que selava seu protagonismo, orientava as ações no âmbito municipal e estipulava metas e objetivos claros. A respeito dela, Eduardo Jorge interpreta que "Um ponto alto de se governo [Kassab] foi a aprovação da primeira Lei Climática do Brasil em 2009, que é uma espécie de código ambiental para a cidade nestes tempos de aquecimento global" (ALVES SOBRINHO, 2013, p. 19).

\subsubsection{Após a promulgação da Política Municipal de Mudança do Clima}

Três meses após a instituição da política municipal, o Comitê Municipal sobre Mudança do Clima também teve sua estrutura alterada, a partir do Decreto n. 50.886, de 22 de setembro de 2009. A partir do decreto o Comitê sofre duas alterações substanciais. Em primeiro lugar, a presidência do Comitê passa da SVMA - que assume a secretaria executiva do Comitê - para a Secretaria Municipal de Desenvolvimento Urbano, representada naquela época na figura do secretário Miguel Bucalem. Outra alteração relevante na estrutura do Comitê refere-se a sua composição. Na estrutura antiga, criada em 2005, o Comitê era ocupado somente por órgãos públicos e a partir de setembro de 2009 passava a ser composto por 11 secretarias e 11 órgãos e instituições fora da estrutura pública, entre elas ICLEI, Fiesp, USP, Anfavea, Greenpeace, Sinduscon e Força Sindical.

A alteração desse instrumento de política pública pode ser compreendida de diferentes óticas. Inicialmente, a passagem da presidência para a SMDU foi uma estratégia deliberada de Eduardo Jorge com o objetivo de fortalecer politicamente o Comitê, uma vez que a SDMU tinha mais prestígio. Ainda em relação a essa alteração, é importante ressaltar que Miguel Bucalem era uma pessoa do círculo pessoal de confiança do prefeito Gilberto Kassab desde os tempos em que ambos cursaram a graduação na Escola Politécnica de Engenharia da USP. A ampliação do quadro de membros do Comitê também merece destaque enquanto estratégia de participação e legitimação 
das políticas a serem implementadas. Por fim, o CMMCE também pode ser interpretado como instrumento de fiscalização do cumprimento das metas estabelecidas.

Após a promulgação da PMMC/SP é possível identificar a implementação de um conjunto relevante de outros instrumentos da ação pública na agenda climática local, como destacado na linha do tempo (Figura 15).

Uma das diretrizes estratégicas da PMMC/SP era direcionada ao setor de transportes, indicado desde o inventário publicado em 2005 como o principal setor emissor de GEEs. Para além das diretrizes, o penúltimo artigo da lei de 2009 estipulava a meta progressiva de redução de combustíveis fósseis na frota municipal de ônibus. Assim, iniciou-se em 2011 o programa denominado Ecofrota, tendo como objetivo buscar fontes de energia limpa para substituir completamente o diesel até 2018. Ainda no ano de 2011 foram introduzidos 200 novos ônibus movidos por fontes de energia limpa. Em 2012 foram lançados 10 novos ônibus, dessa vez movidos a etanol, fruto de um convênio entre a Suécia, a USP e a União da Agroindústria Canavieira do Estado de São Paulo (Única). Nesse sentido, São Paulo foi inovadora mais uma vez, dado que foi a primeira cidade no continente americano a implantar um modelo de ônibus movido a etanol.

Naquele momento a Secretaria Municipal de Transportes estava sob a coordenação de Marcelo Branco (2010-2012). Eduardo Jorge inclusive declarou em entrevista à Revista Página 22, em maio de 2012, que a implementação da Ecofrota foi possível, em grande parte, por causa da atuação de Marcelo Branco. Segundo Jorge, Marcelo Branco reconheceu que "a pauta ambiental está em pé de igualdade com a questão da eficiência no transporte” (ALVES, 2013, p. 124). Além disso, Jorge afirma que, embora a orientação do Prefeito Kassab fosse para que a Secretaria de Transportes trabalhasse de maneira articulada com a SVMA, somente após sete anos de governo e com o terceiro secretário de transportes foi possível essa aproximação e trabalho conjunto.

A Ecofrota pode ser interpretada, portanto, como uma ação da política climática paulistana que sofreu grande influência de pelo menos dois instrumentos da ação pública. Em primeiro lugar, o inventário de emissões de GEEs classificou o setor de transportes como principal "vilão climático" da cidade e, em segundo lugar, a própria política instituída em 2009, que determinou uma meta progressiva de alteração do combustível utilizado pelos ônibus. 
Ainda no ano de 2011 mais uma importante ação no campo climático avançaria, conforme relatado na ata de 20 de outubro do CMMCE. Naquela ocasião, o município já estava um ano atrasado para atualizar seu inventário de emissões de GEEs. Do mesmo modo que o primeiro documento, publicado em 2005, agora a Prefeitura buscava contratar uma entidade tecnicamente capacitada, conforme os padrões do IPCC, para realizar esse trabalho.

A Associação Nacional de Transportes Públicos (ANTP) coordenou uma licitação que contou tanto com a participação de 14 empresas interessadas e com uma doação do Banco Mundial no âmbito do Programa STAQ (Sustainable Transport and Air Quality Program), bem como com recursos do Global Environment Facility (GEF). A respeito dessa questão financeira, Eduardo Jorge destacou em entrevista à Revista Página 22, em maio de 2012, a importância do C40 nesse processo: "O Banco Mundial abriu uma linha de financiamento pela primeira vez direcionada para cidades. Antes, sempre tinha de passar pelas bênçãos dos governos nacionais. Isso é resultado da articulação do C-40" (ALVES SOBRINHO, 2013, p. 120).

Por fim, foi selecionado o consórcio com a Geoklock Consultoria e Engenharia Ambiental Ltda e o Instituto Ekos Brasil, tendo como figuras centrais o físico Délcio Rodrigues, o engenheiro químico João Castro e a Professora Maria de Fátima. Todo o trabalho teve a supervisão técnica da SVMA. O documento final viria a público somente dois anos depois da data inicial da contratação.

Em maio de 2011, o CMMCE, juntamente com seus grupos de trabalho - Transporte, Energia, Construções, Uso do Solo, Resíduos e Saúde -, divulgou o plano para implementação das diretrizes previstas na política municipal criada em 2009 sobre mudanças climáticas: o Plano de Ação da Cidade de São Paulo para Mitigação e Adaptação às Mudanças Climáticas. Nesse documento foram elencados os focos prioritários e ações específicas para cada um dos temas dos grupos de trabalho. Dessa forma, o Plano de Ação representa um instrumento de planejamento para que a cidade de São Paulo conseguisse cumprir os objetivos, diretrizes e metas de sua política.

A divulgação do Plano de Ação representa um indicativo de relativo bom funcionamento do Comitê, que havia sido reorganizado há dois anos de maneira que passasse a incluir uma diversidade maior de membros. A última versão desse documento foi divulgada durante o encontro do C40, que aconteceria na própria cidade de São Paulo naquele mesmo ano. Múltiplas diretrizes são estabelecidas no Plano, entre elas, por exemplo, o conceito de Cidade Compacta, a partir da promoção de "centralidades sustentáveis", adensando a ocupação nos lugares onde há capacidade 
viária instalada, com suporte de transportes, qualidade ambiental e urbanística, além de adequação da capacidade de suporte onde não há.

Em junho de 2011 São Paulo sediaria o C40 Summit, o encontro das maiores cidades do mundo dedicado a tratar dos desafios das mudanças climáticas na perspectiva dos governos locais, sendo a primeira vez que uma cidade da América Latina abrigaria tal evento. A ocasião seria uma oportunidade ímpar para que a Prefeitura de São Paulo, em especial o prefeito Gilberto Kassab e o secretário de meio ambiente, Eduardo Jorge, apresentassem ao mundo as conquistas de seus sete anos de gestão. Vale lembrar que em 2007, quatro anos antes, Kassab havia discursado no próprio C40, em Nova York, sobre seu compromisso com a agenda climática. O ano de 2011 seria, então, o momento de o prefeito confirmar sua promessa.

Em 7 de abril de 2011, um pouco mais de um mês antes do evento, a Prefeitura de São Paulo divulgou uma nota em seu site informando:



Nota-se, portanto, que o encontro do C40 representaria, além de um fórum de encontro, um importante instrumento de comunicação da Prefeitura de São Paulo para apresentar ao mundo seus avanços na agenda climática.

Em dezembro de 2012 chegou ao fim o período do mandato de Kassab à frente da Prefeitura de São Paulo. Durante o período de sua gestão como prefeito (2006-2012), Kassab ganhou uma força política bastante relevante. Em 2005 elegeu-se vice-prefeito da cidade de São Paulo pelo PFL; em 2006 assumiu a dianteira da Prefeitura, quando o então prefeito deixou o cargo; em 2008 disputou as eleições municipais pelo DEM (ex-PFL) e conseguiu se eleger como Prefeito, exercendo seu mandato até 2012, momento em que já havia deixado o DEM e fundado o Partido Social Democrático (PSD) em 2011, exercendo, concomitantemente à prefeitura, a presidência do partido.

2.4.5. Considerações preliminares do capítulo: balanço do governo Gilberto Kassab 
O fim do governo Kassab marca o término do governo mais longevo analisado no âmbito do estudo de caso desta dissertação, com 11 anos de duração e iniciado em 2006. No que se refere à gestão ambiental e à liderança na agenda climática local executada pela SVMA, destaca-se igualmente o término do trabalho de Eduardo Jorge à frente da pasta.

Kassab tem um papel fundamental no desenvolvimento da política climática paulistana. Em primeiro lugar, manteve Eduardo Jorge na chefia da SVMA e na liderança da política climática. Em 2013, um ano após o término do mandato na Prefeitura, o ex-secretário fez uma reflexão a respeito da figura de Kassab:

"Em muitos aspectos ele foi uma surpresa positiva. Procurou claramente evoluir para uma posição política de centro. Manteve e aprofundou orientações técnica e programáticas herdadas de José Serra. Investiu fortemente nas áreas sociais, principalmente saúde, educação e habitação. Mostrou muito interesse na questão ambiental.” (idem, p. 18)

Outro fator característico da gestão Kassab que merece destaque foi a manutenção de determinadas diretrizes que haviam sido estipuladas por Serra, como a orientação de que as demais pastas da Prefeitura trabalhassem de maneira coordenada com a SVMA. Jorge também faz menção a essa característica: "Então, tem um peso fundamental o fato de o prefeito eleito democraticamente falar aos secretários de Transporte, de Saúde, de Educação, de Obras: 'Ouçam o que o meio ambiente vai dizer a vocês e readaptem seus programas e seus projetos"” (ibidem, p. 122).

Além dessas características positivas em relação à construção da política climática, podese dizer que Kassab também foi bem-sucedido em tornar-se uma liderança política local e conseguiu construir uma trajetória política independente de José Serra. Kassab fez importante discurso no encontro do C40 em Nova York em 2007, aprovou a lei municipal que criou a PMMC/SP e sediou o encontro da mesma rede internacional em solo paulistano em 2011, mostrando ao resto das cidades os avanços na agenda climática que o município logrou sob sua liderança.

Ainda que Serra não estivesse mais participando na gestão municipal, é importante considerar o trabalho em conjunto entre o governo municipal e estadual, na época em que Serra era governador, em determinadas ações, a exemplo da construção do parque linear da APA Tietê.

No âmbito local, Kassab fortaleceu o Comitê Municipal e o reestruturou, colocando Miguel Bucalem, secretário da SDMU e amigo desde os tempos de universidade, em sua presidência. 
Merecem destaques as aproximações entre as pastas da educação e de transportes com a SVMA, o que permitiu que ações como a divulgação da Carta da Terra nas escolas da rede municipal, a inspeção veicular e o Ecofrota.

Um dos destaques históricos desse período foi a criação da PMMC/SP a partir da aprovação pela Câmara e da sanção do Executivo da Lei Municipal n. 14.933, em 5 de junho de 2009. Naquele momento São Paulo, mais uma vez, saía na vanguarda climática no Brasil, sendo a primeira cidade do país a ter sua própria lei de mudanças climáticas, antes mesmo que houvesse uma lei nacional que versasse especificamente sobre o tema.

A ausência de liderança do Estado brasileiro nas negociações internacionais foi interpretada no contexto local paulistano como oportunidade de estabelecer São Paulo enquanto protagonista dessa agenda. É interessante notar que instrumentos como o AR 4, divulgado pelo IPCC em 2007, contribuíram substancialmente para que, paulatinamente, as mudanças climáticas passassem a incorporar as preocupações dos atores políticos e sociais. A sociedade aos poucos passou a compreender do que se tratava o aquecimento global, os riscos que esse desafio envolvia e as ações necessárias para tratá-lo.

Do ponto de vista mais global, a gestão que se encerrava em 2012 representava a mais progressista que o município de São Paulo já havia visto nas questões relacionadas às mudanças climáticas. Foi no período de 2005 a 2012 que as mudanças climáticas criaram raízes próprias na gestão municipal paulistana, momento em que os valores e as ideias acoplados à legenda "mudanças climáticas" ganharam força e relevância e se capilarizaram entre uma gama relevante de atores políticos e sociais. Ainda assim, é importante reconhecer mais uma vez que o grupo político vencedor das eleições municipais de 2004 herdou importantes elementos criados na gestão anterior de grupo oponente, que contribuíram para esses progressos.

A cidade de São Paulo durante a prefeitura de Kassab obteve avanços importantes em sua política climática - conforme listado na tabela abaixo - tanto em questões de adaptação, com a criação de áreas verdes, parques lineares, proteção das áreas de mananciais e implantação de ciclovias, quanto em políticas de mitigação de emissão de GEEs a partir da inspeção veicular, do aproveitamento do metano dos aterros sanitários e da promoção da Ecofrota. 
Quadro 6. Tabela com a ideia, os atores, os instrumentos, os fóruns e as ações do governo Gilberto Kassab (2006-2012)

\begin{tabular}{|c|c|}
\hline Ideia & $\begin{array}{l}\text { A mudança climática se estabelece como o principal guarda- } \\
\text { chuva das ações e políticas da SVMA, articulada com as } \\
\text { demais políticas setoriais do governo (transportes, construção } \\
\text { civil, saúde, educação, resíduos sólidos e outras) }\end{array}$ \\
\hline \multirow{7}{*}{ Atores } & Gilberto Kassab \\
\hline & Eduardo Jorge \\
\hline & Alexandre Schneider \\
\hline & José Serra (governador) \\
\hline & Paulo Saldiva \\
\hline & Marcelo Branco \\
\hline & Miguel Bucalem \\
\hline \multirow{11}{*}{ Instrumentos } & UMAPAZ (organizacional) \\
\hline & Carta da Terra (informacional) \\
\hline & Projeto de Lei 530 (normativo/legislativo) \\
\hline & AR 4 (técnico) \\
\hline & Lei Solar (legislativo) \\
\hline & créditos de carbono/MDL (econômico) \\
\hline & inspeção veicular (normativo) \\
\hline & Lei Municipal 14.933/2009 (normativo/legislativo) \\
\hline & $\begin{array}{l}\text { CMMCE - nova presidência e novos membros (de } \\
\text { participação) }\end{array}$ \\
\hline & Plano de Ação/CMMCE (planejamento) \\
\hline & Encontro do C40 em São Paulo (comunicação) \\
\hline \multirow{2}{*}{ Fóruns } & CMMCE com novo escopo \\
\hline & Encontro do C40 em São Paulo \\
\hline \multirow{9}{*}{ Ações } & Operação Defesa das Águas \\
\hline & Programa de difusão da carta da terra nas escolas \\
\hline & Lei Solar \\
\hline & Biogás Aterro São João \\
\hline & Programa de Inspeção Veicular \\
\hline & Ciclovia Caminho Verde \\
\hline & Parque Linear da APA Tietê \\
\hline & Ecofrota \\
\hline & Contratação $2^{\circ}$ inventário \\
\hline
\end{tabular}

De todo modo, do ponto de vista da "contabilidade climática", o município de São Paulo não conseguiu cumprir a meta estipulada em sua Política Municipal de Mudança do Clima (art. $5^{\circ}$ ) de redução de $30 \%$ na emissão de GEEs até o final de 2012. Um levantamento divulgado pela 
ONG Rede Nossa São Paulo relevou que, na verdade, houve um crescimento de 7,2\% na concentração de poluentes 5 .

Este seria o cenário, com os avanços e dificuldades na agenda climática, que o próximo prefeito da cidade herdaria, considerando sua população de mais cerca de 12 milhões de habitantes e uma frota de veículos de mais de sete milhões.

\subsection{Gestão do prefeito Fernando Haddad (PT) (2013-2016)}

Fernando Haddad tem uma formação acadêmica diversificada, com graduação em Direito, mestrado em Economia e doutorado em Filosofia. Sua carreira profissional também é vinculada à academia, sendo professor de Ciência Política na USP. Filiado ao Partido dos Trabalhadores (PT), exerceu o cargo de ministro da Educação de 2005 a 2012 nos governos de Lula e Dilma Rousseff. $\mathrm{Na}$ gestão da prefeita Marta Suplicy em São Paulo, foi subsecretário de Finanças e Desenvolvimento Econômico de 2003 a 2004.

Haddad não tinha um histórico político tão reconhecido pelos paulistanos, mas mesmo assim foi habilitado a concorrer à Prefeitura nas eleições municipais de outubro de 2012, principalmente por causa da influência e capital político do então ex-presidente Lula. Luiza Erundina (PSOL) chegou a ser convidada para compor a chapa na condição de vice-prefeita, mas recusou o convite em razão da coligação que o PT havia formado com PP, PCdoB e PSB. Nádia Campeão, do $\mathrm{PCdoB}$, viria a ser vice-prefeita.

O principal adversário de Haddad nas eleições de 2012 seria José Serra, havendo, portanto, mais uma vez, uma disputa entre os dois partidos, PSDB e PT. Serra já havia ganhado uma eleição municipal em São Paulo em 2004, contra Marta Suplicy (PT). O político tucano também vinha de vitória nas eleições a governador, cargo que ocupou de 2007 a 2010. Seu candidato a vice-prefeito era Alexandre Schneider, filiado ao partido de Kassab, o PSD, e ex-secretário municipal de

${ }^{5}$ Disponível em: http://www.nossasaopaulo.org.br/noticias/emissao-de-poluentes-cresce-72-e-sp-nao-cumpre-lei. Último acesso em 25.mai.2018. 
Educação, cargo ocupado entre 2006 a 2011. Na coligação do PSDB estavam PSD, DEM, PR e PV.

No segundo turno das eleições Haddad ganhou as eleições contra Serra com 55,57\% dos votos, acabando com um período de oito anos de gestão PSDB/PFL/DEM/PSD e recolocando o PT à frente da Prefeitura novamente após 12 anos, quando Marta Suplicy havia ganhado.

Do ponto de vista da agenda climática, a vitória de Haddad representava uma incógnita a respeito da maneira como ele lidaria com essa questão. Em seu programa de governo "Um tempo novo para São Paulo" é possível encontrar apenas em alguns trechos palavras-chave relacionadas, de alguma maneira, a mudanças climáticas. Nesse documento pode-se encontrar o plano de manter o Programa de Implantação de Parques Lineares, fazendo uma referência explícita a esse programa como uma estratégia de adaptação às mudanças climáticas. Quanto aos eixos de mobilidade urbana e transportes e política de biodiversidade e áreas verdes do programa de governo de Haddad, existe a diretriz de investimentos em energias renováveis e substituição dos combustíveis fósseis. Por fim, quanto ao eixo de sustentabilidade ambiental, o inventário de emissões de gases de efeito estufa é citado enquanto orientador de políticas de qualidade do ar e controle de emissões.

Entre as promessas de campanha de Haddad vale destacar o fim do "monopólio da Controlar", empresa responsável pela inspeção veicular, processo este instalado no município de São Paulo desde 2008 com o objetivo de controlar os poluentes do principal setor emissor da cidade. Essa promessa viria a se concretizar nos anos vindouros.

Haddad assumiu a Prefeitura de São Paulo em $1^{\circ}$ de janeiro de 2013 e, para comandar os trabalhos da SVMA, escolheu Ricardo Teixeira (PV). Ricardo havia sido filiado ao PSDB, inclusive concorrendo às eleições de 2010 para o cargo de Deputado Estadual, mas sem lograr êxito. Nas eleições de 2012, Ricardo, agora no PV, disputou as eleições para vereador, conseguindo então se eleger. Curiosamente, no início de 2013, quando deveria iniciar seu mandato na Câmara Municipal, Ricardo é convidado a assumir a SVMA. Outro fato que chama a atenção é que o PV, partido do novo secretário da pasta ambiental, fora integrante da coligação que enfrentou Haddad nas eleições de 2012.

Do ponto de vista do Poder Legislativo, que também se renovara em partes a partir das eleições de 2012, é importante considerar a criação da Frente Parlamentar pela Sustentabilidade, a partir do movimento coordenado pelos vereadores Ari Friedenbach (PPS), Ricardo Young (PPS), 
Floriano Pesaro (PSDB) e Mário Covas Neto (PSDB). Essa Frente Parlamentar viria a se tornar um importante ator no contexto da agenda climática paulistana.

Também no primeiro ano da gestão de Haddad é divulgado oficialmente o $2^{\circ}$ inventário de emissões de gases de efeito estufa do município de São Paulo. O novo inventário atendia às diretrizes da Lei Municipal n. 14.933/09, mais especificamente seu artigo 24 ${ }^{\circ}$, que determinava a obrigação do Poder Executivo de atualizar o inventário de emissões a cada cinco anos. Ainda que com certo atraso, dado que o primeiro inventário fora publicado em 2005, o novo documento divulgado no primeiro ano de governo Haddad - embora houvesse sido contratado em 2011, durante a gestão anterior - representava um potencial instrumento para orientar suas ações.

O documento relevou, então, que as emissões de GEEs do município de São Paulo no período de 2003 a 2009 mantiveram-se próximas a 15 mil GgCO2e, e o ano que contabilizou as maiores emissões foi 2008, quando Kassab disputara as eleições para se manter na prefeitura, conforme a tabela abaixo aponta:

Tabela 1. Emissões totais de GEEs no município de São Paulo

\begin{tabular}{|l|c|c|c|c|c|c|r|}
\hline \multirow{2}{*}{ Setor } & $\mathbf{2 0 0 3}$ & $\mathbf{2 0 0 4}$ & $\mathbf{2 0 0 5}$ & $\mathbf{2 0 0 6}$ & $\mathbf{2 0 0 7}$ & $\mathbf{2 0 0 8}$ & 2009 \\
\cline { 2 - 8 } & \multicolumn{7}{|c|}{$\left(\mathrm{GgCO}_{2} \mathrm{e}\right)$} \\
\hline Resíduos & 2.199 & 2.260 & 2.335 & 2.474 & 2.658 & 2.307 & 2.363 \\
\hline AFOLU & 10 & 10 & 9 & 10 & 10 & 9 & 8 \\
\hline Energia & 12.911 & 13.065 & 12.689 & 12.544 & 13.114 & 13.860 & 12.384 \\
\hline IPPU & 206 & 224 & 251 & 268 & 301 & 350 & 359 \\
\hline Total & 15.326 & 15.558 & 15.285 & 15.295 & 16.083 & 16.526 & 15.115 \\
\hline
\end{tabular}

Fonte: Prefeitura de SP, 2013.

Assim, em novembro de 2013, onze meses após Haddad assumir a Prefeitura de São Paulo, o $2^{\circ}$ inventário de emissões de GEEs do município era publicado, indicando que existia um desafio significativo para conseguir reduzir suas emissões. Restava saber qual seria a utilidade desse diagnóstico e como essa agenda seria tratada.

Ainda no primeiro ano de mandato do novo prefeito, a inspeção foi suspensa com base no argumento de que a vigência do contrato já havia expirado. À época do cancelamento o prefeito informou que a Prefeitura iria abrir nova licitação para que quatro empresas fizessem esse serviço. 
Ricardo Teixeira (PV) era então o secretário do Verde e Meio Ambiente e Jilmar Tatto (PT) o secretário de Transportes. Em janeiro de 2014, a SVMA divulgou as informações referentes à nova concorrência para contratação das empresas que realizariam a inspeção veicular. Não obstante, em maio de 2014, o Tribunal de Contas do Município de São Paulo suspendeu a licitação por considerar que havia dezenove falhas no edital.

Até o final do mandato de Haddad a inspeção veicular não foi retomada. A respeito desse caso, Toninho Vespoli (PSOL), membro da Frente Parlamentar pela Sustentabilidade, relatou em 2016 a seguinte observação: "Por exemplo, na questão da inspeção veicular, que [após os problemas na gestão de Gilberto Kassab] acabou sendo suspensa pelo Haddad. Nós perdemos a batalha, a inspeção foi desmontada na cidade de São Paulo (...)” (SATAFLE, 2016, p. 136).

Já em fevereiro de 2014 o $1^{\circ}$ secretário da SVMA, Ricardo Teixeira, deixava o cargo para comandar a Secretaria de Coordenação das Subprefeituras. Ricardo (PV) ocupou o cargo durante um período de 13 meses. A partir de então, o arquiteto Wanderley Meira do Nascimento viria a ocupar o cargo de secretário na SVMA. Wanderley é filiado ao PT, mesmo partido do prefeito Haddad, e já havia participado da gestão municipal durante o mandato de Luiza Erundina (18891992) que, à época, também era do PT.

Em maio de 2014 a ONG Rede Nossa São Paulo realizou um evento para fazer um balanço da PMMC/SP após os cinco anos de sua vigência. Estavam presentes Oded Grajew e Fernando Beltrame, da Rede Nossa São Paulo, o físico Délcio Rodrigues, do Instituto Vitae Civilis, o integrante da equipe que elaborou o $2^{\circ}$ inventário de emissões, Wanderley Meira do Nascimento da SVMA, o secretário de Serviços, Simão Pedro, o vereador Gilberto Natalini (PV), presidente da Comissão Extraordinária Permanente de Meio Ambiente, o vereador Ricardo Young (PPS), presidente da Frente Parlamentar pela Sustentabilidade, e o vereador Nabil Bonduki (PT).

Os organizadores do evento estavam reivindicando que o governo municipal tomasse medidas para combater o aumento das emissões do município na ordem de $4 \%$ no último ano, entre elas, que cumprisse a meta posta na PMMC em relação à frota de ônibus que utilizasse combustíveis renováveis. Destaca-se aqui o comentário de Natalini, que havia participado dos debates na Câmara em 2008 e 2009, quando a PMMC/SP foi criada: "Quando mudou o governo municipal, nós tivemos a esperança que houvesse continuidade nesse processo, mas observamos que essa questão não é prioridade na atual gestão". 
É importante notar que no dia seguinte ao evento a Prefeitura publicou o Decreto n. 55.129, em 20 de maio de 2014, transferindo a presidência do CMMCE, da SDMU, para a SVMA, e indicando a necessidade da retomada das reuniões do colegiado, que não estavam ocorrendo desde dezembro de 2012. O CMMCE é um órgão consultivo que tem como objetivo dar suporte à implementação da PMMC/SP, inclusive tendo divulgado o documento "Diretrizes para o Plano de Ação da Cidade de São Paulo para Mitigação e Adaptação às Mudanças Climáticas” em maio de 2011. Desde o início da gestão Haddad, em 2013, o órgão não havia mais se reunido. Assim, a retomada de seus trabalhos se deu em agosto de 2014.

Ao resgatar as atas do CMMCE disponíveis no site da Prefeitura é possível fazer um balanço da quantidade de reuniões realizadas desde 2009, quando a estrutura do fórum fora alterada a partir da PMMC/SP. Considerado um dos mais, se não o mais, importante fórum para o debate da política climática no nível local da capital paulista, o Comitê teve um salto muito representativo em termos de seu ritmo de trabalho a partir de 2010, conforme demonstrado na tabela abaixo. Entretanto, em 2013, no primeiro ano do governo Haddad, quando o secretário Fernando de Mello Franco, arquiteto que ocupava a SDMU presidia o CMMCE, o Comitê não se reuniu nenhuma vez. Vale lembrar que a presidência do Comitê havia passado da SVMA para a SDMU durante a gestão Kassab por meio de uma estratégia de Eduardo Jorge de envolver outra área do governo municipal e dar mais peso político para aquele grupo. A partir de 2014, a presidência do CMMCE retorna à SVMA e a agenda de reuniões também é retomada. 
Gráfico 1. Número de reuniões do CMMCE por ano

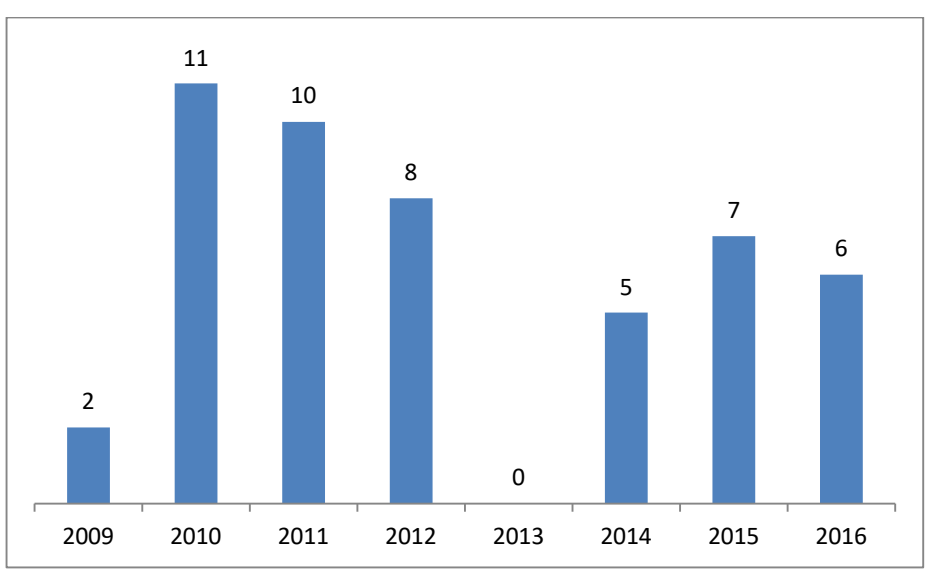

Fonte: Site da Prefeitura de SP. Elaboração do próprio autor.

Em junho de 2015 o Prefeito Fernando Haddad trocou pela terceira vez o comando da SVMA. José Tadeu Candelária, presidente estadual do Partido Republicano (PR), foi então empossado como Secretário do Verde e Meio Ambiente do município de São Paulo. Essa nomeação foi resultado de uma conjuntura eleitoral e de uma aliança partidária pouco compreensível do ponto de vista ideológico, dado que o PT e a sua história estão vinculados às lutas da esquerda, enquanto o PR tem proximidade com as demandas da direita. Esse aspecto político-ideológico, somado ao fato de que se tratava da terceira troca de comando em menos de três anos de governo, são indícios a respeito da importância que o prefeito dava à pasta ambiental.

A iniciativa que mais teve possivelmente relação direta com a agenda climática durante o governo Haddad ocorreu a partir da ação de um representante do Legislativo. Em março de 2015 foi protocolado o PL 167, de autoria do vereador Ricardo Young (PPS). Na verdade, o conteúdo desse PL se baseou em uma proposta elaborada pela sociedade civil, mais especificamente as ONGs Iniciativa Verde, SOS Mata Atlântica, Imaflora e Associação Águas Claras do Rio Pinheiros, tendo como objetivo instituir a obrigatoriedade de elaboração de inventários de emissões de GEEs e a implantação de medidas de compensação nos eventos de grande porte que acontecessem no município de São Paulo. Entretanto, esse projeto de lei não teve nenhum avanço.

Em dezembro de 2015 o Ministério Público Estadual (MPE) abriu inquérito para investigar o cumprimento da Lei n. 14.933, que instituiu a Política Municipal de Mudança do Clima e suas 
respectivas metas. A atenção do MPE esteve especialmente direcionada à meta que constava no artigo 50 da legislação mencionada, que diz:

\begin{abstract}
"Os programas, contratos e autorizações municipais de transportes públicos devem considerar redução progressiva do uso de combustíveis fósseis, ficando adotada a meta progressiva de redução de, pelo menos, $10 \%$ (dez por cento) a cada ano, a partir de 2009 e a utilização, em 2018, de combustível renovável não-fóssil por todos os ônibus do sistema de transporte público do Município"
\end{abstract}

Assim, por causa do contexto daquela época de nova licitação dos ônibus da cidade, o MPE determinou que a Prefeitura apresentasse um planejamento e um cronograma para cumprir essa meta. No entanto, a situação à época era bastante desfavorável, uma vez que um pouco mais de 4\% da frota de ônibus pertencia ao programa Ecofrota, criado em 2011.

Em abril de 2016 a Câmara Municipal, mais especificamente a Comissão Extraordinária de Meio Ambiente, presidida pelo vereador Gilberto Natalini, novamente interferiu para exigir que a Prefeitura se atentasse para as metas da PMMC/SP ao promover o debate "Programa Ecofrota em São Paulo: porque parou e como avançar". Em setembro de 2017 o Conselho Superior do Conselho Nacional de Autorregulamentação Publicitária (CONAR) autuou a gestão do prefeito Haddad, a partir de denúncia encaminhada por Natalini, por propaganda enganosa ao colar os adesivos "Ecofrota" em ônibus que não se enquadravam tecnicamente no programa de combustíveis renováveis. Segundo notícia veiculada no jornal Estado de S. Paulo, Natalini alega que o programa Ecofrota sofreu "completo retrocesso" pela gestão Haddad.

Em fevereiro de 2016, último ano do mandato de Haddad na Prefeitura, durante a cerimônia de posse de Ricardo Young para a presidência da Frente Parlamentar pela Sustentabilidade, o vereador, agora filiado à Rede Sustentabilidade, citou a necessidade da cidade de São Paulo retomar os compromissos postos na PMMC/SP, se planejar e de fato atuar politicamente na agenda climática. $\mathrm{O}$ fato é que, ao se observar os avanços e retrocessos, os erros e acertos da gestão de Haddad, fica claro que as mudanças climáticas não entraram na pauta do Poder Executivo.

Ao analisar os quatro anos de governo do prefeito Fernando Haddad, é possível afirmar que as mudanças climáticas enquanto ideia, considerando os valores que convergem nesse espectro político, perderam força. O campo das políticas sociais tornou-se a grande bandeira de Haddad, em detrimento de qualquer conjunto de ações que pudesse combater as mudanças climáticas, seja do ponto de vista da mitigação ou da adaptação. 
Diferentemente da última gestão petista na prefeitura de São Paulo, com Marta Suplicy (2001-2004), quando as primeiras ações no campo climático foram implementadas, pode-se dizer que houve um significativo retrocesso da agenda no governo Haddad. Praticamente todos os programas e ações que vinham sendo implementados há alguns anos foram descontinuados, ou seja, além das mudanças climáticas perderem forças como ideia, também deixaram de ser o "guarda-chuva" que fora ao longo dos últimos anos, articulando e promovendo um conjunto de políticas de diferentes setores (educação, saúde, transportes, entre outros).

Um dos fatores que mais chama a atenção na gestão de 2013 a 2016 foi a constante alternância na gestão da SVMA. Foram três diferentes secretários ao longo de quatro anos. Esse fator indica a importância que o chefe do Poder Executivo dava às questões ambientais e, além delas, à própria política climática, que vinha sendo encampada e articulada pela pasta ambiental.

Há que se ponderar, entretanto, alguns avanços durante a gestão Haddad que contribuíram para o campo climático, ainda que essa nomenclatura não fora utilizada pelos líderes políticos.

O inventário publicado em 2013 manteve a indicação do primeiro inventário de 2005: a de que o setor de transportes era o principal emissor de GEEs. Nesse sentido, o setor de transportes teve uma relativa prioridade na gestão Haddad, mais especificamente no que se refere ao transporte coletivo de ônibus e as vias específicas para bicicletas. Em relação aos ônibus, de fato as faixas exclusivas e corredores aumentaram (412 km de vias criadas com prioridade para circulação de ônibus). Porém, em contrapartida, a Ecofrota, que tinha como objetivo substituir integralmente o combustível da frota para um modelo renovável não fóssil, não teve avanços, havendo, inclusive, desrespeito a uma meta específica da PMMC/SP. Quanto às ciclovias, também houve uma promoção substancial, com mais de $400 \mathrm{~km}$ para bicicletas, mas com a crítica de alguns especialistas em relação ao seu planejamento e custo.

Mesmo considerando que os avanços no setor de transporte coletivo de ônibus e a expansão das ciclovias e ciclo faixas tenham um impacto direto nas emissões de GEEs e, portanto, estejam intrinsicamente ligados à agenda climática, torna-se evidente que, do ponto de vista do discurso, o governo Haddad não vinculava essas ações ao "guarda-chuva" climático.

Além disso, ainda no setor de transportes, a política climática para o transporte individual, a partir da inspeção veicular, que havia sido implementada em 2008, foi totalmente desmontada na gestão de Haddad. 
Quadro 7. Tabela com a ideia, os atores, os instrumentos e as ações do governo Fernando Haddad (2013-2016)

\begin{tabular}{|c|c|}
\hline Ideia & $\begin{array}{l}\text { A mudança climática perde espaço enquanto ideia e dá } \\
\text { espaço para políticas sociais }\end{array}$ \\
\hline \multirow{7}{*}{ Atores } & Fernando Haddad \\
\hline & Ricardo Teixeira \\
\hline & Wanderley do Nascimento \\
\hline & José Tadeu Candelária \\
\hline & $\begin{array}{l}\text { Frente Parlamentar pela Sustentabilidade: Ari Friedenbach } \\
\text { (PPS), Ricardo Young (PPS), Floriano Pesaro (PSDB) e Mário } \\
\text { Covas Neto (PSDB) }\end{array}$ \\
\hline & Ministério Público Estadual \\
\hline & Gilberto Natalini \\
\hline \multirow[t]{2}{*}{ Instrumentos } & $\begin{array}{l}\text { Plano de governo - parques lineares, energias renováveis, } \\
\text { qualidade do ar e controle de emissões (planejamento) }\end{array}$ \\
\hline & 20 inventário de emissões \\
\hline \multirow{2}{*}{ Ações } & Aumento das ciclovias e ciclofaixas \\
\hline & Promoção do transporte coletivo de ônibus \\
\hline
\end{tabular}

Interessante destacar a avaliação que Gil Scatena, assessor de planejamento urbano do então vereador Ricardo Young, faz sobre a gestão do prefeito Haddad, relatada no livro "Um mandato em quatro atos", de Amália Safatle (2016):

\begin{abstract}
"A gestão dele [Haddad] tem coisas muito alinhadas com a sustentabilidade, como a ciclovia, o Plano Diretor, a retomada das faixas de ônibus, mas ele não consegue colocar isso no diapasão da sustentabilidade. Como se entrelaçam as coisas? Não posso falar em mobilidade calcada em bicicleta e em ônibus se eu abandono a lógica da substituição das fontes fósseis dos ônibus [o diesel] para combustíveis limpos, que Eduardo Jorge [secretário do Verde e do Meio Ambiente da gestão anterior] tinha iniciado. E se abandono as políticas de mudança climática, entramos em um período sem metas e sem prazos" (SAFATLE, 2016, p. 118).
\end{abstract}

As ponderações de Scatena corroboram a interpretação de que, ainda que algumas ações e políticas implementadas pelo governo Haddad tenham sido positivas do ponto de vista da mitigação e adaptação, estas perdem força se não estão alinhadas a uma estratégia que considere explicitamente os desafios climáticos e, mais do que isso, se enfraquecem quando as demais ações de seu governo vão contra as diretrizes mais elementares, como a inspeção veicular e a substituição do combustível da frota de ônibus.

De maneira geral, é possível notar durante o governo de Fernando Haddad uma alteração no "centro gravitacional climático paulistano", saindo do Poder Executivo, que ocupara esse 
protagonismo nos anos anteriores, para o Legislativo. Ainda assim, o balanço desse período é significativamente negativo para a agenda climática.

Por fim, do ponto de vista teórico, uma análise do governo Haddad permite elaborar algumas reflexões.

Em primeiro lugar, resgatando a abordagem cognitiva de Muller (1990), a partir da qual o autor afirma que as políticas públicas são "ideias em ação", somada à concepção de Sabatier (1993) de que as "ideias são a cola das instituições", é possível ensaiar algumas ponderações sobre o período histórico paulistano de transição do governo Kassab para o governo Haddad. Nitidamente, os valores agregados às políticas climáticas foram incorporados pela gestão de Kassab, assumindo esse discurso e, em seguida, utilizando-o para aferir ganhos políticos, enquanto a gestão de Haddad praticamente desconsiderou os valores do aquecimento global e da sustentabilidade, quase como se estes fossem exclusividade de outros grupos políticos que não o seu. Haddad aproximou, nesse sentido, sua gestão aos valores historicamente vinculados a políticas sociais. Ainda assim, o prefeito petista poderia ter utilizado o discurso social sem deixar de promover ações alinhadas aos desafios climáticos. Na maior parte da sua gestão, não foi isso que aconteceu. Talvez a inexistência dessa "cola" na passagem de bastão da Prefeitura tenha sido um dos principais motivos para a descontinuidade de grande parte das políticas climáticas que estavam em curso ou sendo planejadas.

Uma segunda observação teórica que esse momento da política paulistana permite é em relação ao conceito de ciclo de políticas públicas. Esse conceito existe pelo menos desde 1956, a partir da produção de Harold Lasswell e tem sido trabalhado por uma diversidade de autores desde então. Sua ideia fundamental é determinar e classificar um conjunto de etapas na formulação de políticas de públicas, desde sua concepção, criação, implementação até sua avaliação. Entretanto, o que a realidade demonstra é que o conceito de ciclo acaba sendo fragilizado por outros fatores com maior relevância política, como o contexto, os atores que estão na liderança, os discursos e as ideologias, para ficar somente com alguns exemplos.

No caso de São Paulo, por exemplo, o fato de a legislação adotada em 2009 ter determinado metas, objetivos e diretrizes para a política climática paulistana não significa que, necessariamente, suas implementações e respectivas avaliações serão a próxima etapa, o que de fato aconteceu. Nesse sentido, a produção acadêmica de Cortese (2013), ao mesmo tempo que se estabelece em 
bases frágeis ao desenvolver uma análise da política pública sob o ponto de vista de sua etapa de implementação, corroborando o conceito de ciclo, percebe a fragilidade dessa abordagem:

\begin{abstract}
“O maior desafio está na mudança de comportamento, dos hábitos estabelecidos, a necessária revisão de valores. As parcelas da população ou grupos econômicos impactos (sic) irão reagir contrariamente às propostas; caso essa reação encontro apoio nos meios de comunicação, poderá sensibilizar ampla parcela da população e significar um ônus político expressivos para os responsáveis pela sua implantação. Portanto é fundamental existir vontade política." (p. 117).
\end{abstract}

\title{
2.6. Considerações finais do capítulo
}

A análise dos acontecimentos ao longo dos anos descritos no capítulo 3 indica um processo de construção paulatina da política de mudanças climáticas do município. A observação dos fatos a partir das diferentes "lentes" teóricas permitiu qualificar a reflexão, sobretudo as categorias de análise selecionadas.

O modo gradativo como esse processo se deu indicou que, embora as mudanças climáticas ainda não representassem um apelo político de grande magnitude no Brasil no início da década de 2000, foi no governo da prefeita Marta Suplicy, com a participação dos secretários Stela Goldenstein e Adriano Diogo, na SVMA, que as primeiras ações concretas foram implementadas. Nesse período destacam-se a inserção do município de São Paulo na rede internacional de governos locais, o ICLEI, a contratação do $1^{\circ}$ inventário de emissões de GEEs e o início do aproveitamento energético a partir dos gases emitidos no aterro sanitário Bandeirantes.

As mudanças climáticas passaram a ser assumidamente um campo, de característica multisetorial, no governo municipal de São Paulo a partir de 2005, quando o prefeito José Serra assumiu a Prefeitura, legitimando e fortalecendo politicamente a SVMA, na figura de Eduardo Jorge, orientando que todas as demais pastas trabalhassem de maneira alinhada às diretrizes ambientais. É a partir desse momento que as mudanças climáticas passam, pouco a pouco, a representar um campo de valores assumidamente encampado pelas lideranças políticas. A partir de então, um conjunto de instrumentos e ações relacionados à agenda climática são postos em prática.

Do período de 2005 a 2012, durante os oitos anos em que Jorge esteve na SVMA, sendo o secretário mais longevo do período analisado aqui, é possível identificar uma atuação desse ator enquanto o mediador da política climática paulistana. Resgatando o conceito de Pierre Muller 
(1990), o mediador é a figura com a capacidade de construir um significado objetivo para um conjunto de valores. Nesse sentido, Jorge tem a capacidade de "aterrissar" os ideais da sustentabilidade, da harmonia da vida em sociedade com os limites da natureza, da busca pelo equilíbrio entre bem-estar social e os limites ecossistêmicos, do aquecimento global, em ações concretas que o poder público municipal executaria. Os acontecimentos descritos ao longo do capítulo 3 permitem identificar uma liderança tanto intelectual quanto política de Eduardo Jorge, com uma capacidade singular de articular a maioria das secretarias, inserir o município de São Paulo em redes internacionais e aproximar atores da academia e da sociedade civil para lidar com um determinado desafio.

O ponto alto da trajetória descrita ao longo do capítulo é a institucionalização da política de mudanças climáticas a partir da legislação aprovada e sancionada em junho de 2009, que criou a Política Municipal de Mudança do Clima. Essa lei referendou e legitimou um protagonismo que o município vinha constituindo ao longo dos anos. Com a Lei Municipal n. 14.933, de 5 de junho de 2009, São Paulo passaria a ser a primeira cidade do Brasil a ter uma lei específica que versasse sobre o tema, antes mesmo da própria Federação e do estado de São Paulo. Essa liderança encontraria reflexos, inclusive, nos espaços que a cidade ocuparia, por exemplo, em fóruns internacionais, como foi o caso do encontro do C40 em São Paulo no ano de 2011.

Em entrevista à Revista Página 22, em setembro de 2008, Eduardo Jorge, ainda na época ocupando o cargo de secretário municipal do Verde e Meio Ambiente, fez a seguinte reflexão:

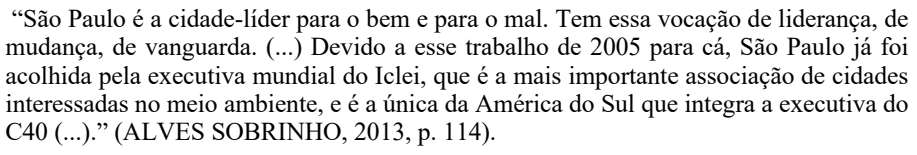

"São Paulo é a cidade-líder para o bem e para o mal. Tem essa vocação de liderança, de mudança, de vanguarda. (...) Devido a esse trabalho de 2005 para cá, São Paulo já foi acolhida pela executiva mundial do Iclei, que é a mais importante associação de cidades interessadas no meio ambiente, e é a única da América do Sul que integra a executiva do C40 (...).”(ALVES SOBRINHO, 2013, p. 114).

Para além da legislação propriamente dita, a cidade avançou na agenda climática a partir de um conjunto de instrumentos de ação pública, de diferentes naturezas (econômico, de planejamento, normativo e demais), que permitiram a implementação de ações concretas extremamente relevantes. A política climática impactou uma diversidade de setores da administração municipal, como a educação, com a divulgação da Carta da Terra na rede municipal de ensino; a saúde, com o Programa Ambientes Verdes e Saudáveis (PAVs); a construção civil, com a lei que obrigou a instalação de aquecedores solares em novas edificações; os transportes, com a inspeção veicular, a criação da ciclovia na Radial Leste e a substituição dos combustíveis dos ônibus para uma matriz renovável não fóssil com a Ecofrota. 
Em 2013 iniciou-se em São Paulo um novo momento político, a partir do mandato do prefeito Fernando Haddad, que havia ganhado as eleições contra José Serra e havia prometido desde o período eleitoral rever a inspeção veicular. Um balanço geral do governo Haddad demonstra que as mudanças climáticas não representaram, definitivamente, uma bandeira política da nova administração. Ainda que algumas iniciativas do novo governo impactassem positivamente o desafio climático, especialmente com a promoção do transporte coletivo e de bicicletas, o saldo foi negativo, com uma série de retrocessos, a exemplo da Ecofrota e da inspeção veicular.

No próximo capítulo o leitor encontrará um aprofundamento das análises a respeito da construção da política climática paulistana ao longo dos quatro governos em análise, tendo como base as informações e as reflexões extraídas das entrevistas realizadas. 
4. Capítulo 3 - Análise do caso de São Paulo a partir das entrevistas

A realização das entrevistas foi de extrema importância para compreender uma série de aspectos-chave que influenciaram a política climática paulistana. Em termos metodológicos, as entrevistas foram construídas de forma semiestruturada e representaram uma etapa imprescindível para qualificar o desenvolvimento desta presente dissertação. $\mathrm{O}$ acúmulo advindo da pesquisa bibliográfica, com destaque às demais produções acadêmicas descritas no capítulo anterior, somado ao repertório teórico, permitiram aproveitar as entrevistas de modo a esclarecer como a agenda climática foi incorporada e institucionalizada no município de São Paulo e identificar os principais instrumentos e atores, descobertas estas que serão compartilhadas nesse capítulo.

A introdução da presente dissertação iniciou a construção do raciocínio jogando luz para a importância crescente de abordagens locais para os desafios impostos pelas mudanças climáticas. Nesse sentido, o caso da cidade de São Paulo foi muito relevante, uma vez que o município teve um protagonismo significativo no cenário nacional, sendo o primeiro município a ter sua própria política climática, a partir da promulgação da lei em junho de 2009, antes mesmo do próprio estado de São Paulo e da União. Essa liderança não se traduziu apenas por meio do instrumento legal, mas igualmente por uma série de ações, programas e articulações que promoveram o avanço de políticas de mitigação e adaptação no município de São Paulo, que, em grande parte, foram implementados antes mesmo da legislação de junho de 2009.

Por causa desse contexto, descrito em detalhes no capítulo 3, o primeiro desafio da pesquisa científica foi tentar identificar os motivos e instrumentos que estimularam e possibilitaram esse protagonismo.

\subsection{Quando as mudanças climáticas entraram na agenda?}

Um ponto de consenso entre os entrevistados foi de que, a partir do início do governo de José Serra, em 2005, com a posse de Eduardo Jorge na SVMA, as mudanças climáticas passaram a fazer parte do centro da estratégia de atuação dessa pasta, estando presente no cerne da maioria dos discursos e das ações. Somado a esse acontecimento de ordem política e à imagem das duas figuras políticas, alguns dos entrevistados também relembraram que o inventário das emissões foi publicado logo no início do ano de 2005 e que esse instrumento também colaborou para a institucionalização do problema. 
Ao mesmo tempo que esse reconhecimento emergiu nas entrevistas, durante as falas também foi ressaltado o fato de que durante o governo de Marta Suplicy, desde seu início em 2001, quando Stela Goldenstein era Secretária do Verde e Meio Ambiente, algumas ações já vinham sendo implementadas, ainda sem grande peso e relevância política. Entre as iniciativas que já estavam em desenvolvimento desde 2001-2002, Stela ressaltou durante sua entrevista quatro exemplos. O primeiro exemplo destacado foi a renegociação do contrato de aproveitamento energético no aterro Bandeirantes, incluindo a obrigatoriedade de que $50 \%$ da receita da venda de créditos de carbono via MDL fosse direcionado aos cofres da Prefeitura. O segundo exemplo tratou da polêmica questão da inspeção veicular que, com o auxílio prestado por José Eduardo Cardozo - em várias ocasiões ele atuava como assessor direto da prefeita Marta Suplicy, apesar de não estar na Prefeitura - e Belisário dos Santos Júnior pôde ser construída a estrutura jurídica do contrato. Em seguida, ainda na época em que Stela era secretária, parte da frota de ônibus foi substituída para utilizar fontes renováveis. Por fim, foi iniciada a elaboração do termo de referência para contratação do inventário de emissões.

Foi em 2003 que a cidade de São Paulo aderiu ao ICLEI e ao seu programa Cities for Climate Protection (CCP) e seus respectivos compromissos - um deles o de ter um inventário de emissões. Nesse ano, Stela Goldenstein já havia deixado a SVMA e Adriano Diogo havia assumido a chefia da pasta. Duas entrevistas realizadas durante a investigação desta dissertação revelaram descobertas significativas a respeito do processo de aproximação do ICLEI com São Paulo e do período de transição entre Stela Goldenstein e Adriano Diogo na Secretaria.

Laura Valente começou a trabalhar no ICLEI em 2002, quando essa rede transnacional tinha sua representação para América Latina instalada na cidade do Rio de Janeiro. Naquela ocasião, Laura coordenava a campanha CCP. Desde 2002, Laura já havia iniciado um processo de aproximação com São Paulo, muito por causa do contato que tinha com a então secretária Stela Goldenstein. Ambas se conheciam desde a época do mandato de Fábio Feldman na Secretaria Estadual do Meio Ambiente (1995-1998), quando Stela era secretária-adjunta e Laura era assessora de Feldman. Esse histórico profissional auxiliou, portanto, nessa aproximação entre o ICLEI e a cidade paulistana. Assim, em março de 2002, ICLEI e SVMA organizaram e promoveram conjuntamente um debate sobre mudanças climáticas na cidade de São Paulo. 
Outra revelação tão ou mais importante que emergiu durante a entrevista realizada com Laura Valente foi o fato de que o novo secretário, Adriano Diogo, que assumiu em 2003, deu continuidade à relação e ao trabalho em conjunto que vinha sendo construído. Segundo Laura, Adriano demonstrou enorme interesse pela agenda climática e rapidamente formalizou a parceria com o ICLEI e, já logo em seguida, contratou a COPPE/UFRJ para a elaboração do inventário de emissões de gases de efeito estufa.

Por meio da entrevista com Adriano Diogo surgiram duas descobertas. A primeira foi a de que o entrevistado recebeu com bastante surpresa o convite da então prefeita Marta Suplicy para assumir a SVMA a partir de 2003. Naquela época, Adriano Diogo havia participado das eleições de outubro de 2002 e havia sido eleito deputado estadual pelo PT, mesmo partido da prefeita na época, com mais de 85 mil votos. Entretanto, segundo os relatos do entrevistado, o acordo supostamente existente entre Marta e Serra havia sido rompido na época. Foi esse acordo que permitiu que Stela Goldenstein, historicamente próxima a José Serra, estivesse à frente da SVMA nos dois primeiros anos da gestão Marta. Por fim, Marta convidou Adriano Diogo para chefiar a SVMA a partir de janeiro de 2003 e ele aceitou, abrindo mão de seu mandato enquanto deputado estadual nos anos de 2003 e 2004.

A segunda descoberta feita a partir da conversa com Adriano diz respeito aos motivos que o entusiasmaram para aceitar a parceria com o ICLEI, sendo esta uma aproximação iniciada no mandato de sua antecessora. O entrevistado aqui confirma que essa aproximação e a parceria formalizada representavam uma oportunidade política e técnica. Era política porque, sendo o ICLEI uma rede transnacional, esta permitia a inserção da cidade de São Paulo em uma grande quantidade de fóruns e espaços internacionais, e técnica porque o ICLEI, segundo o entrevistado, era uma "universidade ambulante", com alta capacidade de conhecimento e que também permitia estimular e qualificar o quadro da SVMA com viagens e cursos internacionais. Além de tudo isso, não havia nenhum prejuízo nem exigência de contrapartida financeira.

Ainda que a construção da política e seus instrumentos, como o inventário e o mecanismo do MDL, tenham sido frutos de um processo paulatino, ficou clara sua institucionalização a partir de 2005. Segundo os comentários de Stela Goldenstein durante a entrevista realizada, "O discurso das mudanças climáticas começou a existir oficialmente na administração municipal [de São Paulo] a partir da gestão Serra, sobretudo pela articulação de Eduardo Jorge. Os debates que 
estavam sendo feitos no âmbito federal e nas negociações internacionais contribuíram igualmente para esse avanço da agenda".

Mais do que ter sido reconhecido como um problema, as mudanças climáticas passaram, então, durante todo o período do mandato de Eduardo Jorge na SVMA, de 2005 a 2012, a ser o grande "guarda-chuva" que legitimava e fortalecia a maioria das ações, programas e políticas.

Um esclarecimento inicial se fez necessário, de modo a compreender os motivos de um ator historicamente vinculado à agenda da saúde e medicina sanitarista como Eduardo Jorge ter encampado e encabeçado esse processo de implantação e institucionalização da agenda climática no seio da administração municipal de São Paulo. Durante a entrevista concedida pelo próprio Eduardo Jorge e as entrevistas dos demais participantes do estudo de caso, foi possível identificar elementos centrais para esse ocorrido.

Em primeiro lugar, a preocupação com o meio ambiente esteve presente na vida de Eduardo Jorge desde sua infância no interior da Paraíba, conforme o próprio entrevistado relatou, fato este que contribuiu para a criação de uma "relação afetiva" com os desafios ambientais no mundo contemporâneo. Do ponto de vista da formação profissional, Eduardo Jorge ressaltou sua compreensão de que a área da saúde e a área ambiental são muito próximas, uma vez que a promoção de saúde está atrelada fortemente à existência de um meio ambiente saudável.

Em relação à trajetória política de Eduardo Jorge, foram destacados dois nomes. De início, Vitor Buaiz (PT/ES), também médico de formação e ex-deputado constituinte. Eduardo e Vitor moraram na mesma casa em uma determinada época, além de integrarem o mesmo partido naquele momento. Essa aproximação teve influência na construção da perspectiva ambiental que Eduardo Jorge construiu ao longo de sua carreira, pois Buaiz era um ativista nessa agenda. Outra pessoa importante destacada ao longo da entrevista, que também teve uma relação próxima com Eduardo Jorge e influenciou sua formação ambiental no campo político foi Fábio Feldman. Eduardo e Fábio também foram companheiros no Congresso Nacional durante a Constituinte. O nome de Fábio Feldman também surgiu como um ator importante na questão climática e na relação que teve com Eduardo Jorge nas entrevistas de Mônica Ribeiro e Volf Steinbaum.

Uma descoberta significativamente relevante ao longo da entrevista com Eduardo Jorge realizada para a presente dissertação foi o fato de o prefeito recém-empossado, José Serra, ter feito um alerta direcionado ao então Secretário do Verde e Meio Ambiente, desde o início do mandato, 
para a importância e relevância da questão climática. Nas demais produções científicas que analisaram igualmente esse período, a informação até então existente era a força e apoio político que Serra deu a Eduardo Jorge e a diretriz clara de integração entre as secretarias, colocando a Secretaria do Verde e Meio Ambiente no primeiro escalão das pastas. Com a fala de Eduardo Jorge durante a entrevista nota-se que houve uma questão para além do reforço genérico, havendo também um alerta específico para os perigos que as mudanças climáticas significavam para as cidades, considerando os aprendizados e as ações efetivas que vinham sendo desenvolvidas em demais locais do mundo. Na entrevista, Eduardo Jorge inclusive reconhece que José Serra é "um político habilidoso e com sensibilidade para o assunto climático".

\subsection{A influência do contexto internacional}

O contexto internacional, com seus fóruns e instrumentos relevantes e determinadas articulações com forte inserção na realidade paulistana, foram destacados por alguns entrevistados ao longo das entrevistas para esta dissertação. O aspecto internacional foi importante tanto para sensibilizar determinados atores políticos-chave em relação aos desafios da questão climática em grandes centros urbanos quanto para igualmente perpetuar essa preocupação e multiplicá-la entre atores políticos, sociedade, academia e iniciativa privada, possibilitando, ao longo dos anos, a execução de uma série de iniciativas.

O primeiro fato internacional lembrado por Eduardo Jorge foi a Rio 92. O encontro organizado pelas Organizações das Nações Unidas no Rio de Janeiro foi um momento de divulgação do $1^{\circ}$ relatório do IPCC e da consequente criação da Convenção-Quadro das Nações Unidas sobre a Mudança do Clima. Segundo Eduardo Jorge, todos esses fatores, somado ao fato de o encontro ter acontecido em território nacional, geraram um ambiente favorável para que um conjunto de atores se debruçasse sobre a agenda climática. Mônica Ribeiro, responsável pela comunicação da SVMA durante a gestão de Eduardo Jorge, foi outra entrevistada que também reconheceu a importância da Rio 92 e sua influência para o contexto local de São Paulo.

Nota-se durante as entrevistas realizadas uma ausência significativa. Em 2001, primeiro ano do mandato da Prefeita Marta Suplicy, acontecia a COP 7 em Marrakesh, no Marrocos, ao mesmo tempo que era divulgado o AR3 do IPCC. Ainda que esses acontecimentos representem fatos importantes em termos da agenda climática, eles não foram mencionados por nenhum entrevistado. 
Outro acontecimento internacional que foi lembrado em algumas ocasiões, direta ou indiretamente, foi o Protocolo de Kyoto, tratado internacional negociado entre os países-membros da UNFCCC em 1997. O que justifica o fato de esse acontecimento ter sido citado indiretamente por alguns entrevistados se deve à referência ao conteúdo desse documento, mais especificamente ao instrumento de Mecanismo de Desenvolvimento Limpo (MDL).

Conforme Stela Goldenstein destacou, entre os anos de 2001 e 2002, houve uma renegociação importante do contrato de aproveitamento energético no aterro Bandeirantes, operado por uma empresa privada, de modo que $50 \%$ da receita advinda da venda de créditos de carbono fosse direcionada aos cofres da Prefeitura. Eduardo Jorge, por sua vez, ressaltou a relevância do papel de Francisco Vidal, Secretário Municipal de Planejamento de 2005 a 2007, na modelagem das licitações que colocaram à venda os créditos de carbono dos aterros sanitários Bandeirantes e São João. Em setembro de 2007 foi realizada a primeira experiência mundial de leilão de Reduções Certificadas de Emissões realizada por uma Bolsa de Valores (BM\&F), em parceria com a prefeitura de São Paulo. Foram leiloados 808.450 toneladas de dióxido de carbono equivalente (CO2e), correspondentes ao período de 2003 a 2006, gerados nos termos do Mecanismo de Desenvolvimento Limpo (MDL) pelo Projeto Bandeirantes de Gás de Aterro e Geração de Energia, e emitidos pelo Conselho Executivo do MDL - ONU. O leilão gerou a arrecadação de R\$ 34 milhões.

Em relação aos dois principais fóruns e as articulações com os quais São Paulo esteve conectado - o ICLEI desde 2003 e o C40 desde 2005 -, Eduardo Jorge os classifica como "espaços de aprendizagem" muito importantes para a cidade, pois permitiam a troca de experiências, o intercâmbio de conhecimentos e as aproximações com realidades que enfrentam desafios similares. Alguns exemplos foram citados pelo entrevistado a respeito dessa articulação internacional, como uma viagem a Londres, organizada pela então Secretária Municipal de Relações Internacionais, Helena Gasparian, ocasião em que Eduardo Jorge encontrou-se com a vice-prefeita de Londres, além das viagens coordenadas por Adalberto Maluf pelo C40 e Laura Valente pelo ICLEI.

Uma fala específica de Eduardo Jorge durante a entrevista realizada representa uma boa síntese dos motivos que fizeram com que a questão climática entrasse na agenda da cidade de São Paulo: “A questão climática representa um 'guarda-chuva' que permite você reorganizar as ações, 
incorporar uma diversidade de pautas e articular de maneira intersetorial. Além disso, é uma possibilidade de ganhar força política, sobretudo pela sua relevância internacional”.

Essa fala e os itens descritos acima permitem traçar paralelos interessantes com diferentes correntes teóricas das políticas públicas e da ação pública. Começando com a vertente tradicional, nota-se que houve uma racionalidade deliberada de aproveitar as oportunidades econômicas e políticas que poderiam ser colhidas com essa agenda: em termos econômicos, a venda de crédito de carbonos e, em termos políticos, o protagonismo da cidade em relação aos governos estadual e federal e a exposição em fóruns internacionais.

Entretanto, essa racionalidade foi limitada e outros fatores foram incorporados. Ao considerar demais aspectos, outras escolas teóricas nos disponibilizam ferramentas mais adequadas para compreender as dinâmicas e complexidades da ação pública. O governo Serra/Kassab, com Eduardo Jorge na SVMA, herdou alguns dispositivos bem encaminhados que foram corretamente interpretados, reforçados e utilizados, como o inventário de emissões e o aproveitamento energético dos aterros sanitários. Nesse caso, trata-se de uma oportunidade circunstancial.

Por último, as contribuições da ação pública nos permitem considerar aspectos como a circulação de ideias e os valores. A circulação das ideias foi mencionada algumas vezes por diferentes entrevistados, como as descobertas científicas consolidadas nos relatórios do IPCC, a Rio 92 e as COPs subsequentes e as viagens e fóruns internacionais organizados pelo ICLEI e C40 para conhecer as experiências de outras grandes cidades. Em termos de valores, houve o reconhecimento intelectual por parte especificamente de José Serra e Eduardo Jorge a respeito da importância dos desafios impostos pelas mudanças climáticas, junto com os valores sociais advindos da infância, da carreira médica e da carreira política de Eduardo Jorge.

Estes foram os principais acontecimentos internacionais citados pelos entrevistados que tiveram, em diferentes medidas, impulsos para que a agenda climática "vingasse" na cidade de São Paulo. Além destes, durante o transcorrer dos anos, é possível identificar outros fatos internacionais que influenciaram diretamente no avanço da política climática paulistana.

Nos primeiros anos de mandato de Eduardo Jorge à frente da SVMA, o próprio secretário construiu uma parceria entre a Secretaria, a FGV e o ICLEI para organizar os conhecimentos presentes em documentos e experiências internacionais e o próprio conteúdo do inventário 
municipal de emissões para elaborar uma base científica sólida que justificasse as ações da SVMA na agenda climática. Essa parceria teve como objetivo explícito criar um anteprojeto de lei que propusesse a instituição da Política Municipal de Mudança do Clima. Em relação a essa iniciativa, a entrevistada Rachel Biderman destacou o apoio financeiro do PNUD como instrumento essencial para viabilizar esse trabalho, representando mais um fato internacional relevante para a política em questão.

A COP 15 que aconteceu em Copenhaguen, na Dinamarca, em 2009, foi relembrada por Eduardo Jorge como um acontecimento de grande relevância para o contexto local paulistano. O encontro internacional que o Estado brasileiro participaria gerou consequências no sentido de alertar os vereadores da Câmara Municipal de São Paulo acerca da importância das questões climáticas, além de demonstrar para eles a oportunidade política que São Paulo tinha de "sair na frente" do governo federal. Na ocasião, já tramitava desde agosto de 2008 na Câmara Municipal o Projeto de Lei que propunha a Política Municipal de Mudança do Clima. Copenhaguen contribuiu, portanto, positivamente para o avanço da pauta de maneira mais pacífica entre os vereadores.

Ainda nesse sentido, Fabio Feldmann sublinhou em sua entrevista que, tão importante quanto a COP 15, em 2009, foi a divulgação a do $4^{\circ}$ Assessment Report do IPCC em 2007. Segundo Feldmann, foi a partir desse momento que a comunidade científica - rede epistêmica, nos termos da abordagem teórica aqui considerada - "saiu do muro" e afirmou claramente que as mudanças climáticas estavam em curso e que a ação antropogênica era a principal responsável. Por causa disso, houve uma reverberação do conteúdo do relatório nas grandes mídias, nas capas de revistas nacionais e internacionais, o que, de certa maneira, abriu os olhos dos políticos para a importância da temática. Assim, o entrevistado julga que esses dois fatos somados propiciaram um ambiente favorável, que contribuiu positivamente tanto para o âmbito municipal quanto para a promulgação das políticas de mudança climáticas do estado de São Paulo e do país em novembro e dezembro de 2009, respectivamente.

O C40 também emerge enquanto articulação internacional com forte relevância no contexto climático local de São Paulo. Do ponto de vista histórico, dois acontecimentos se destacam. Em 2007, ano de pré-eleições municipais, Kassab fez um fatídico discurso no encontro do C40 em Nova Iorque, quando se comprometeu a aprovar uma política de mudanças climáticas para São Paulo. Já em 2011, também ano pré-eleitoral, aconteceu o encontro do C40 na cidade de São Paulo, oportunidade em que a gestão do então prefeito Kassab teve a oportunidade de mostrar ao mundo 
o que vinha fazendo nessa agenda. Previamente a esse encontro em São Paulo em 2011, o então secretário Eduardo Jorge publicou um artigo intitulado "Nenhum a menos", documentado no livro "Três ou quatro sementes de araçá". Nesse texto, Jorge apresenta o desafio das mudanças climáticas, as ações que estavam sendo realizadas pela Prefeitura e a importância do C40.

"Falo de São Paulo e nossos problemas com eventos climáticos extremos, chuvas,
inundações e desabamentos. (...) Neste contexto, é importante destacar a realização, na
cidade de São Paulo, da edição 2011 da Conferência da Rede C40 de Grandes Cidades
(C-40 Large Cities Climate Leadership Group) neste mês de maio. (...) Estarão em São
Paulo prefeitos e técnicos de cidades como Amsterdã (...) Rio de Janeiro, dentre outras,
reunidos para incentivar a cooperação internacional no sentido de reduzir as emissões de
carbono e promover ações entre as instituições privadas e governos nacionais a fim de
reduzir os efeitos do aquecimento global.” (Alves Sobrinho, 2013, p. 35)

Adalberto Maluf, representante do C40 em São Paulo no período de 2007 a 2014, compartilhou comentários interessantes durante a entrevista a respeito do papel da articulação internacional no âmbito local. Segundo Maluf, esses fóruns internacionais eram percebidos ao longo da gestão Kassab tanto como uma oportunidade de intercambiar experiências quanto de expor seus avanços internos em um ambiente internacional. Em relação ao C40, Maluf entende que este era notado pela administração local, especificamente na figura de Eduardo Jorge, enquanto espaço e instrumento para importar boas práticas em termos de políticas climáticas.

Por fim, o Banco Mundial foi citado por Volf Steinbaum como um ator importante na política climática paulistana. Foi essa instituição financeira que viabilizou a contratação para elaboração do $2^{\circ}$ inventário de emissões de gases de efeito estufa do município já em 2012.

5.3. O mediador, os instrumentos e a rede da política climática paulistana

Feitas as observações a respeito de como a "ideia" a respeito das mudanças climáticas foi capturada e institucionalizada na realidade paulistana, considerando a conjuntura, as oportunidades que emergiram daí, os determinados valores defendidos por algumas pessoas e a circulação de ideias, cabe agora comentar duas categorias de análise selecionadas na presente dissertação. Conforme aprofundado no capítulo 2, as abordagens teóricas dos instrumentos da ação pública e os mediadores representam essas duas categorias de análise.

Antes de adentrar propriamente na análise a partir das "lentes" teóricas selecionadas, vale uma observação mais genérica a respeito da figura do ator. Já no capítulo teórico foi esclarecida a 
importância dos atores no desenvolvimento das análises, uma vez que são eles quem viabilizam a transformação de determinadas ideias, considerando suas redes de relações e os instrumentos, em políticas públicas. Uma das características mais importantes dos atores analisados é sua capacidade de liderança.

É deveras curioso que - e por isso o devido destaque aqui -, em mais de uma entrevista, foi ressaltado o fato de que o avanço das políticas públicas depende em grande parte da existência de uma liderança capaz de promover determinada agenda. Para citar ao menos dois exemplos, Fabio Feldmann argumentou que o avanço de determinadas políticas, especialmente na área ambiental, depende de lideranças tanto no governo quanto na sociedade. Volf, por sua vez, defendeu a ideia de que o avanço de uma política pública guarda forte relação com a presença de um agente articulador que a promova. Esse tipo de análise feita pelos entrevistados é fundamental para compreender a capacidade e o ritmo dos avanços de determinadas políticas. Somadas essas percepções e experiências empíricas juntamente com as contribuições teóricas, é possível esboçar um elemento-chave para compreender a ação pública no Brasil.

Inicialmente, para avançar a análise dos atores, é importante resgatar o conceito de mediador de políticas públicas presentes nas obras de Pierre Muller e Gilles Massardier, considerando que as abordagens propostas pelos autores franceses se distanciam do reportório clássico e levam em consideração os aspectos de ordem cognitiva. Nesse sentido, a figura do mediador exerce uma função primordial de construir uma coerência social em torno de valores - referencial setorial e global -, de modo que seus pares e demais setores também trabalhem nesse mesmo sentido. Vale dizer que o mediador tem a capacidade de sensibilizar um conjunto de atores importantes para transformar uma ideia em políticas públicas.

Isso posto, e por tudo o que foi escrito e descrito até aqui nesta dissertação, torna-se evidente a centralidade de Eduardo Jorge durante o processo de construção e implementação da política climática paulistana. Entretanto, vale a pena dar um passo atrás e observar quem ocupava cargo hierarquicamente superior ao de Eduardo. Nesse sentido, o prefeito José Serra, que venceu as eleições de 2004, foi quem o convidou a chefiar a pasta da SVMA. Mais do que o convite, o próprio Eduardo destacou em sua entrevista a diretriz dada por Serra em 2005 a respeito da importância da questão climática para os municípios, sobretudo os de grande porte como São Paulo. O entrevistado ressaltou, inclusive, a sensibilidade de Serra para a questão climática. 
Apesar da importância de Serra enfatizada acima e dos fatos descritos e analisados ao longo dessa dissertação, a análise final que o autor defende é de que não é possível considerá-lo um mediador. O primeiro motivo para que embasa essa negação do seu papel como mediador é o fato de Serra ter ocupado o cargo de prefeito de São Paulo somente por 14 meses, uma vez que tomou posse em janeiro de 2005 até março de 2006, quando renunciou ao cargo para concorrer à eleição de governador do estado de São Paulo, ganhando no primeiro turno, em outubro de 2006. Assim, ainda que Serra tenha estabelecido importantes diretrizes desde 2005 e formatado parte do governo municipal, nomeando, por exemplo, Eduardo Jorge, que se manteve até 2012, não foi ele quem conduziu e liderou os processos relacionados à política climática paulistana.

O segundo principal motivo considerado para não classificar Serra enquanto mediador da política climática é o fato de que, durante sua gestão no governo do estado de São Paulo - que tampouco se efetivou até o prazo final de quatro anos, dado que Serra também renunciou ao cargo em abril de 2010 para concorrer pela segunda vez à Presidência da República -, essa agenda não demonstrou avanços significativos. Vale reconhecer, entretanto, que o governo de São Paulo também promulgou uma lei específica de mudanças climáticas cinco meses após o município (PEMC), em novembro de 2009, quando Francisco Graziano Neto era o Secretário Estadual de Meio Ambiente. A criação do Comitê Gestor da PEMC, grupo integrado por membros de 12 secretarias do estado, foi efetivada somente em junho de 2010, ou seja, após a saída de Serra do governo. Dessa forma, a agenda climática avançou de maneira muito tímida na gestão estadual, sobretudo quando comparada com as iniciativas que foram sendo desenvolvidas no nível municipal.

Esses dois motivos impossibilitam considerar José Serra um mediador da política climática no município de São Paulo, conforme as características destacadas por Muller.

Feitas as considerações acerca de José Serra, é possível avançar as análises a respeito de Eduardo Jorge, ator que ocupou o cargo de chefia da pasta da Secretaria do Verde e Meio Ambiente durante oito anos consecutivos (2005-2012). Filiado ao Partido Verde (PV), grupo político com uma herança ecológica significativa, Eduardo e especificamente a SVMA estiveram à frente de um conjunto grande de iniciativas incorporadas aos discursos das mudanças climáticas, como descrito ao longo do capítulo 3 desta dissertação. 
A pergunta que fica, portanto, é: Eduardo Jorge foi o mediador? A partir das conclusões desenvolvidas pelo autor desta dissertação e das observações feitas explicitamente pelos entrevistados, é possível considerar Eduardo Jorge o mediador da política climática paulistana à luz do referencial teórico de Muller e Massardier.

De início, nota-se a existência de determinadas sinergias entre o que o referencial teórico estipula e as características de Jorge em termo de valores, referenciais, capacidade de articulação e resultados empíricos de sua trajetória na SVMA.

O vínculo de Jorge com as questões ambientais está atrelado a sua trajetória de vida, desde sua infância no interior da Paraíba, conforme o próprio entrevistado comentou. Outro aspecto importante de ser destacado é a concepção de saúde defendida por Jorge, a qual guarda uma relação próxima com atitudes que garantem condições para o gozo de uma vida saudável, ou seja, a promoção de saúde e não o tratamento de doenças. Foi exatamente essa ideia de saúde que fortaleceu a ligação de Jorge com os temas ambientais, como explicou na entrevista.

Dessa forma, do ponto de vista dos valores, nota-se que as questões ambientais e uma determinada interpretação de promoção de saúde e prevenção de doenças guiaram a trajetória e a formação de Jorge. Seguramente, esses aspectos influenciaram sua sensibilidade e imersão na agenda climática, considerando suas dimensões de mitigação e adaptação.

Os conceitos de referencial global e setorial também auxiliam o desenvolvimento da análise de Jorge enquanto mediador. Retomando brevemente, o referencial global é baseado nos valores fundamentais e nas normas de conduta que orientam a ação pública, enquanto o referencial setorial diz respeito à maneira como determinado setor influencia a organização social. Entre as qualidades que se destacam de um determinado mediador está sua capacidade de articular os dois referenciais para produzir uma coerência social compartilhada entre uma série de atores.

Do ponto de vista dos valores fundamentais, ou seja, do referencial global, Eduardo Jorge sofreu, portanto, uma influência em relação às questões ambientais. O próprio ressaltou em sua entrevista a existência de alguns eventos que contribuíram para consolidar esses valores, sobretudo no que concerne especificamente às problemáticas climáticas. Entre eles foi dado destaque a Rio 92 e a consequente criação da Convenção-Quadro sobre mudanças climáticas e o Protocolo de Kyoto. 
Em termos de referencial setorial, não há dúvidas de que a saúde representou o principal alicerce para que Eduardo Jorge fosse capaz de produzir uma ação pública eficaz na agenda climática. Sublinham-se aqui sua formação acadêmica enquanto médico sanitarista, sua atuação profissional e política no campo da saúde, sobretudo na Zona Leste, e sua participação como deputado na elaboração da Constituição Federal, especialmente com a criação do Sistema Único de Saúde.

Nesse sentido, Mônica Ribeiro, responsável pela coordenação da comunicação da SVMA, salientou em sua entrevista a estratégia de a saúde ser o "carro-chefe" dos discursos de Eduardo Jorge para avançar a política climática na cidade, pois a saúde sempre foi uma área em que Jorge tinha uma capacidade de transitar e uma facilidade de comunicação muito grandes. Esse elemento traduziu-se empiricamente em uma série de iniciativas, como o PAVs e as ações de controle de emissão de poluentes por veículos automotores.

Em relação à capacidade de liderança intelectual e política do mediador, destaca-se o fato de que todos os entrevistados elogiaram essa qualidade de Eduardo Jorge. Fabio Feldmann, ator político relevante no campo climático brasileiro, classificou Jorge como um "empreendedor climático". Hélio Neves, chefe de gabinete de Jorge durante sua gestão na SVMA, enfatizou a "capacidade incomum" do chefe da pasta em abrir diálogos com outras áreas e mudar comportamentos. Stela Goldenstein, que esteve à frente da SVMA entre 2001 e 2002, sublinhou a capacidade de Jorge em ser um hábil articulador. Rachel Biderman, que trabalhava na FGV e participou da elaboração da minuta do PL, classificou Jorge como uma "liderança carismática".

Outra qualidade do mediador ressaltada pelos autores teóricos é a capacidade de formatar uma rede de parcerias, articulando entre si os atores de cada rede e gerando um objetivo compartilhado a partir de uma ideia comum, que permita promover ações efetivas. Essa capacidade é possível de ser identificada no trabalho desenvolvido por Eduardo Jorge.

O resgate do conceito teórico de redes de políticas públicas auxilia no desenvolvimento e na análise dessa ideia. De certa maneira, a organização em redes resulta da dinâmica policêntrica que as relações sociais apresentam na contemporaneidade. Assim, as redes são organizadas a partir de elementos normativos, ou por influência de instituições públicas, ou então como resultado de um sentido cognitivo compartilhado entre seus membros. Cada tipo de rede tem suas características específicas em termos de estabilidade e abertura para entrada e saída de membros. 
De maneira geral, existem as "redes de projetos", as "comunidades de políticas públicas" e as "comunidades epistêmicas". O caso da política climática paulistana e o conjunto de atores que se organizaram em torno dessa agenda configuram a formatação de uma comunidade de política pública. A literatura descreve as comunidades como um grupo que compartilha um sentido cognitivo, uma "raison pour agir" em relação a uma política pública que os reúne (MASSARDIER, 2003, p. 134).

O resgate dos acontecimentos e os atores descritos ao longo do capítulo 3 e as descobertas documentadas no capítulo 4 desta dissertação permitem identificar a comunidade de política pública que se formatou, tendo em vista a função que Eduardo Jorge desempenhou enquanto lídermediador. Para fins didáticos, os principais atores serão identificados em três subgrupos: a equipe de Eduardo Jorge na SVMA, os parceiros no governo municipal e os parceiros fora do governo.

Entre a equipe da SVMA, destacam-se Hélio Neves, Volf Steinbaum, Mônica Ribeiro, Rose Marie Inojosa e Leda Aschermann. Hélio foi chefe de gabinete de Jorge durante quase todo seu mandato, deixando o cargo apenas para assumir a liderança de um processo judicial referente ao programa de inspeção veicular. Segundo o próprio Hélio, durante a entrevista concedida para esta dissertação, a função de chefe de gabinete se equipara a um "clínico geral”, atuando e apoiando o gestor em todos os temas e frentes de trabalho. Volf, por sua vez, foi coordenador do programa de inspeção veicular e secretário-executivo do Comitê Municipal de Mudanças Climáticas, enquanto Mônica foi responsável pela comunicação da SVMA, especialmente de Jorge, durante seu mandato, além de tê-lo acompanhado em sua candidatura para presidente em 2014. Já Rose Marie foi Diretora da Umapaz de 2005 a 2012, integrando e representando também a SVMA no GT de resíduos no Comitê de Mudanças Climáticas, enquanto Leda foi suplente de Eduardo Jorge no comitê de mudanças climáticas.

Dessa equipe da SVMA dois nomes merecem destaque: Hélio Neves e Volf Steinbaum. Hélio Neves foi chefe de gabinete e, durante a entrevista realizada com ele, surgiram alguns indicadores que o apontam como sendo o responsável por lidar com a burocracia interna da administração pública, objetivando viabilizar as iniciativas e programas da SVMA. A relação de Hélio com a Procuradoria da Prefeitura e os servidores da própria SVMA, conforme relatado pelo entrevistado, permitiram vencer os eventuais entraves da burocracia, permitindo, assim, que as ideias de Eduardo Jorge e sua equipe se tornassem realidade. Já Volf Steinbaum tinha uma trajetória profissional de longa data dentro das administrações municipal e estadual que o 
credenciava a ter diversos interlocutores. Era funcionário de carreira da Cetesb e já trabalhava com as questões técnicas de controle de poluição do ar. As informações compartilhadas durante a entrevista concedida, juntamente com a análise dessa trajetória, dão indícios de que Volf era um interlocutor técnico com facilidade de trânsito entre os servidores da SVMA, as demais secretarias e os membros das equipes das secretarias estaduais, inclusive. Assim, enquanto Hélio auxiliava na viabilização das pendências burocráticas, Volf exercia uma capacidade técnica que qualificava uma série de iniciativas.

Em relação aos parceiros dentro da estrutura burocrática na gestão municipal, Jorge conseguiu estabelecer uma relação de parceria com vários deles, especialmente com os demais secretários municipais, muito em função das diretrizes dadas pelos prefeitos Serra e Kassab, com as quais a SVMA ganhou forte legitimidade e relevância nessas relações. Foram dezenas de secretários que Jorge teve como companheiros de gestão ao longo dos oito anos à frente da SVMA e alguns tiveram maior proximidade e relevância na política climática. Entre os nomes mais centrais mapeados ao longo das leituras e entrevistas estão Marcelo Branco, Miguel Bucalem, Alexandre Schneider, Francisco Vidal e Helena Gasparian.

Branco foi secretário de Infraestrutura e Obras (2006-2010) e de Transportes (2010-2012), sendo esse último cargo de grande relevância para as políticas de mobilidade e controle de poluição que Jorge pressionava para que avançassem, como a Ecofrota de ônibus e o programa de inspeção veicular. Branco foi tão importante que a admiração de Jorge por ele ficou registrada no livro "Três ou quatro sementes de araçá" e foi relembrado por Mônica Ribeiro em sua entrevista dada para esta dissertação: "Mas agora, aonde eu vou, em palestras do mundo inteiro, o secretário, de vilão virou mocinho. Eu digo a ele: 'Marcelo Branco, você é meu herói’” (2013, p. 124).

Bucalem, por sua vez, foi secretário de Desenvolvimento Urbano de 2009 a 2012, ou seja, após Kassab vencer a eleição de 2008. Durante esses mesmos anos, a partir de setembro de 2009, quando o Comitê de Mudanças Climáticas foi reorganizado (Decreto n. 50.866/2009) a partir de uma estratégia deliberada de Eduardo Jorge, Bucalem assumiu a presidência do Comitê Municipal de Mudança do Clima e Economia. Em relação a essa aproximação entre Eduardo Jorge e Miguel Bucalem, ou entre SVMA e SMDU, Rachel Biderman, quando entrevistada, afirmou que: "A parceria entre EJ e Bucalem foi muito feliz, foi uma combinação perfeita". Segundo ela, enquanto Jorge exercia uma liderança carismática dentro do comitê, Bucalem tinha uma organização e capacidade para conduzir os trabalhos e cumprir os prazos. 
Schneider foi Secretário de Educação de 2006 a 2012 e trabalhou conjuntamente com Jorge na introdução da Carta da Terra na rede municipal de ensino, além de auxiliar na criação da Umapaz, em 2005. Vidal foi Secretário de Planejamento de 2005 a 2007 e, conforme Jorge relembrou em sua entrevista para esta dissertação, ele teve um papel central na licitação internacional dos créditos de carbono (MDL) provenientes do aproveitamento energético dos aterros Bandeirantes e São João, além de contribuir na construção do arranjo que permitiu que esse dinheiro fosse direto para os cofres do Fundo Municipal de Meio Ambiente (Fema). Gasparian foi outra colega de Jorge também relembrada por ele durante a entrevista, ressaltando a importância dela para a inserção da cidade nos principais fóruns internacionais e criação de conexões que permitiram importar iniciativas de política climática de outros locais para São Paulo.

Para além dos colegas no Poder Executivo, um nome surgiu de maneira reiterada nas revisões bibliográficas e entrevistas no âmbito da Câmara Municipal: o vereador Gilberto Natalini. Durante os oito anos de mandato de Jorge à frente da SVMA, Natalini foi vereador no Poder Legislativo paulistano, tendo uma participação importante na condução do projeto de lei que criou a Política Municipal de Mudanças Climáticas dentro da casa legislativa. Em diversas entrevistas, inclusive na de Eduardo Jorge, Natalini foi considerado um importante articulador e facilitador desse processo na Câmara Municipal de Vereadores. O próprio Natalini declarou durante a entrevista que incorporou a função de "tradutor" das questões climáticas junto aos seus companheiros vereadores e suas respectivas equipes, tendo, inclusive, feito uma sessão de cinema para apresentar o filme do ex-vice-presidente dos EUA, Al Gore, "Uma Verdade Inconveniente", em 2007.

O último subgrupo que compôs a rede de ação pública liderada pelo mediador Eduardo Jorge era composto por parceiros que não estavam no governo e eram representantes da academia e de redes transnacionais de articulação. É importante notar que os três atores ressaltados aqui se aproximaram e integraram, em graus diferentes, a rede da política climática paulistana, seja pela influência de Eduardo Jorge ou de Fábio Fedlmann.

Da parte da academia, destaca-se Rachel Biderman, integrante do Centro de Estudos em Sustentabilidade da Fundação Getúlio Vargas e com participação relevante na elaboração do anteprojeto de lei que criou a política de mudança climática da cidade. Rachel é formada em Direito e trabalhou com Feldman quando este era Secretário Estadual de Meio Ambiente, entre 
1996 a 1998. Na ocasião, Biderman trabalhou com questões relacionadas à poluição, ao rodízio de veículos e a demais iniciativas fortemente vinculadas às mudanças climáticas.

Em relação às redes transnacionais, Laura Valente, diretora do ICLEI para América Latina, foi notadamente uma importante parceira da SVMA em vários momentos relacionados à política de mudança climática. Laura se formou em Arquitetura, mas seu vínculo com as questões ambientais teve início ao participar como voluntária na campanha de Feldmann para concorrer ao cargo de deputado constituinte, elegendo-se em 1986. Posteriormente, Laura colaborou e trabalhou com Fabio em seu mandato de deputado federal na Secretaria Estadual de Meio Ambiente e no Fórum Brasileiro de Mudanças Climáticas, percurso este que a inseriu e a qualificou na agenda climática.

Por fim, Adalberto Maluf, personagem importante para o desenvolvimento da política climática paulistana, foi diretor do C40 em São Paulo de 2007 a 2012, vivenciando, portanto, as gestões de Kassab em dois mandatos e a metade do mandato de Fernando Haddad. Maluf formouse na primeira turma de Relações Internacionais da USP e no início do mandato do prefeito Serra começou a trabalhar na SMRI. Já em 2006, Eduardo Jorge o convidou para ser seu assessor dentro da SVMA para assuntos internacionais, momento em que Maluf passa a integrar de maneira direta a rede de política climática local, com a influência direta do chefe da pasta de meio ambiente.

Nota-se, portanto, o destaque a 14 atores-chave, além dos dois prefeitos, que compuseram a rede articulada por Jorge. Desse total, sete atores foram entrevistados para esta dissertação. A maioria desses nomes descritos nos parágrafos acima esteve presente na resposta à última pergunta feita aos entrevistados (Anexo 1), pedindo para que citassem o nome de três pessoas centrais que deveriam ser entrevistados pelo autor desta investigação.

Além desses nomes mencionados acima, outros também foram citados, mas os resultados da pesquisa indicam que estes tiveram relações mais pontuais com as iniciativas lideradas por Jorge. Os secretários de Meio Ambiente do estado de São Paulo, José Goldemberg (2002-2006) e Xico Graziano (2007-2010), são exemplos de lideranças que tiveram relações substancias com Jorge, mas que não foram incorporados a sua rede, segundo a leitura e interpretação do autor desta dissertação. Goldemberg, entre outros assuntos, negociou as compensações ambientais ao município de São Paulo por causa das obras do trecho norte do Rodoanel, enquanto Graziano tratou das compensações ambientais ao município de São Paulo em função da obra de ampliação das vias 
da Marginal Tietê. Outra liderança que também participou de forma relevante da construção da política climática paulistana foi o médico e professor da USP, Paulo Saldiva, que influenciou com informações científicas e participações na mídia para defender as políticas de restrição de automóveis individuais e o impacto que os motores à combustão geram na saúde pública. Porém, tampouco Saldiva pode ser considerado um membro da rede.

Ainda há a figura de Fabio Feldmann, um dos políticos mais reconhecidos do campo ambiental, grande responsável pelo capítulo sobre meio ambiente na Constituição Federal por causa de sua ativa participação enquanto deputado constituinte. O nome de Fabio Feldmann surgiu na maioria das entrevistas realizadas.

Política e historicamente, Fabio teve proximidade com o círculo de José Serra (PSDB). Ele havia sido Secretário Estadual de Meio Ambiente na gestão de Mário Covas (PSDB), quando Stela Goldenstein fora a secretária-adjunta (1995-1998). Laura Valente já havia igualmente trabalhado com Feldmann. Em relação à Eduardo Jorge, Feldmann o conhecia desde a época da Constituinte e, desde então, tiveram boas relações, sobretudo na intersecção das agendas da saúde com a do meio ambiente. Em 2010, Feldmann disputou as eleições para governador do estado de São Paulo pelo Partido Verde (PV), mesmo partido de Eduardo Jorge.

Do ponto de vista da construção da narrativa climática no Brasil, Feldmann também exerceu uma participação de destaque, seja nas negociações com governo federal, seja nas negociações com os governos estadual e municipal. Ele havia sido chefe da delegação brasileira dos parlamentares na Rio 92, bem como membro oficial da delegação brasileira nas Conferências das Partes da Convenção Quadro das Nações Unidas sobre Mudanças Climáticas, de 1997 a 2002, entre elas a que culminou com o Protocolo de Kyoto. O ambientalista foi o primeiro secretárioexecutivo do Fórum Brasileiro de Mudanças Climáticas (2000-2004) e também o primeiro secretário-executivo do Fórum Paulista de Mudanças Climáticas Globais e de Biodiversidade (2005-2010).

Feldmann participou do contexto municipal de São Paulo como consultor contratado pela FGV, quando trabalhou com Rachel Biderman - outra integrante da rede de política pública descrita acima - da elaboração da minuta do projeto de lei que originou a Política Municipal de Mudança do Clima. 
Dessa maneira, apesar de Fabio Feldmann não estar intrinsicamente presente na rede de política pública da qual Eduardo Jorge era o principal mediador, ele exerceu uma influência importante na construção dessa teia de relações, bem como na inserção da agenda climática em nível nacional.

Considerando todas as informações expostas, juntamente com o resgate conceitual e teórico sobre a figura do mediador e as redes de políticas públicas, nota-se a capacidade desenvolvida por Eduardo Jorge entre os anos de 2005 a 2012, quando chefiou a pasta da SVMA. Suas características pessoais, seus valores e ideais e sua capacidade de articular uma rede de atores foram capazes de gerar uma coerência social que resultou em mudanças práticas que impactaram o cotidiano dos cidadãos paulistanos. De toda sorte, é importante considerar que o mediador não tem superpoderes e sozinho não consegue gerar as mudanças desejadas; por isso, ele se utiliza de sua capacidade de construir alianças e criar relações com interlocutores para construir uma coerência social e fazer com que suas ideias se transformem em ações. Essas mudanças foram descritas e registradas ao longo do capítulo 3 desta dissertação.

Esta comunidade (rede) da política climática paulistana, sob liderança de Eduardo Jorge, foi capaz de implementar um conjunto de instrumentos da ação pública que permitiram o avanço dessa agenda. Ao mesmo tempo, esses dispositivos técnicos e sociais (LASCOUMES e LE GALÈS, 2012) colaboraram para a construção de uma coerência social direcionada para a implementação de políticas de mitigação e adaptação.

Resgatando a classificação proposta por Lascoumes e Simard (2011), é possível identificar, ao menos, a existência de instrumentos econômicos, legislativos, normativos e comunicacionais.

Do ponto de vista econômico, a venda de créditos de carbono no mercado internacional, via MDL, a partir do aproveitamento energético dos aterros Bandeirantes e São João, teve uma importância central para o processo de legitimação da política climática junto aos agentes políticos locais e a sociedade como um todo. Nesse processo o então secretário de planejamento, Francisco Vidal, foi decisivo. Conforme descrito, esses instrumentos começaram a serem implementados desde os anos de 2001 e seguiram sendo utilizados ao longo dos anos.

Ainda no campo econômico, um fator que também fortaleceu a política climática foi o aumento do orçamento da SVMA, saindo de R\$ 75 milhões em 2005 para R\$ 400 milhões em 2012, equivalendo a 1,1\% de todo orçamento da Prefeitura. Sendo a SVMA a pasta que assumiu a 
liderança da política climática, o fortalecimento de seu orçamento contribuiu indiretamente para as iniciativas climáticas. A importância do aumento da capacidade orçamentária da pasta ambiental é relembrada em diversas ocasiões, seja no livro "Três ou quatro sementes de araçá", em que Eduardo Jorge atribui grande parte dessa conquista à força que o prefeito Kassab deu a questão ambiental, seja nas entrevistas dadas por ele. Hélio Neves, chefe de gabinete de Eduardo Jorge, compreende, por sua vez, que os avanços na agenda climática foram possíveis por causa da capacidade de Jorge de criar vínculos intersetoriais e do fortalecimento do orçamento interno da SVMA.

O principal instrumento legislativo que consolidou e indicou os avanços necessários para a questão climática na cidade de São Paulo foi a própria Lei 14.933 de junho de 2009, que criou a Política de Mudança do Clima, indicando metas e objetivos claros. Mais do que um instrumento legislativo local, a lei também desempenhou um papel de instrumento político, uma vez que legitimava a cidade de São Paulo no cenário nacional e internacional, exigindo inclusive que a União e o Estado também tivessem suas próprias leis. Nesse caso, a pressão surtiu efeitos a curto prazo, dado que em menos de cinco meses o estado de São Paulo criava sua política estadual e em seis meses era promulgada a política nacional de mudanças climáticas. Para a construção e aprovação da lei, figuras como Fabio Feldmann, Rachel Biderman, Laura Valente, Volf Steinbaum e Gilberto Natalini tiveram grande importância.

Em relação à construção do texto da $\mathrm{PMMC/SP}$, uma descoberta relevante surgiu durante a entrevista com Fabio Feldmann. O entrevistado, que fora Secretário Estadual de Meio Ambiente de 1995 a1998, destacou que, no processo de elaboração da minuta do projeto de lei, da qual ele participou a partir da FGV, foram resgatados trechos da proposta de lei que instituía a Política Estadual de Controle da Poluição Veicular e de Transporte Sustentável. Essa proposta fora apresentado pela própria SMA em 1998, quando Feldmann era secretário, mas não teve sucesso. De todo modo, parte de seu conteúdo foi resgatado para ser incorporado na primeira proposta que daria origem a PMMC/SP. Nesse sentido, é interessante notar a capacidade de representar parcialmente um mesmo instrumento, com uma nova roupagem, em um novo contexto, mas com propósitos similares.

A maioria dos entrevistados no âmbito desta dissertação chamou a atenção para o fato de que o conteúdo do projeto de lei enviado pelo Executivo para ser apreciado na Câmara Municipal foi bastante "arrojado", incluindo metas objetivas e que exigiram um grande esforço para que 
fossem cumpridas. Stela Goldenstein fez um comentário adicional em relação à legislação, reconhecendo sua importância, mas relativizando sua capacidade de influência em questões práticas. Segundo a ex-Secretária Estadual de Meio Ambiente, a lei que cria a PMMC/SP tem um caráter simbólico relevante; porém, não garante os avanços necessários. Hoje, dezenove anos depois da criação da política, nota-se que, de fato, a legislação não assegurou os avanços e que as metas não foram cumpridas.

O inventário de emissões de gases de efeito estufa do município, publicado em 2005, pode ser considerado um instrumento normativo central para a política climática paulistana. Foi esse documento que, em sua origem, o ICLEI, na figura de Laura Valente, foi o grande animador, diagnosticando a situação da cidade. De certa maneira, além de cumprir um papel de alerta, comunicacional, o ICLEI também norteou as ações, como as necessárias iniciativas de controle de poluição do setor automotivo, muitas delas coordenadas por Volf Steinbaum e Hélio Neves. A importância do inventário encontra-se, inclusive, documentada na publicação oficial da Prefeitura de São Paulo, intitulada "Diretrizes para o Plano de Ação da Cidade de São Paulo para Mitigação e Adaptação às Mudanças Climáticas”, publicada em maio de 2011. Nesse material, na abertura escrita por Eduardo Jorge, encontra-se:

\footnotetext{
"O instrumento que desde 2005 norteia as ações é o Inventário de Emissões de Gases de Efeito Estufa da Cidade de São Paulo. (...) Foram inventariados uso de energia, mudança de uso no solo e florestas, setor agropecuário, disposição final de resíduos sólidos e tratamento de esgotos domésticos e comercias e de efluentes industriais" (Prefeitura de São Paulo, 2011, p. 10).
}

O Comitê de Mudança Climática foi um espaço importante de articulação, troca de informações e legitimação da agenda, podendo, portanto, ser considerado um instrumento de ordem comunicacional de extrema relevância. Nesse caso, Volf Steinbaum e Leda Ascherman desempenharam funções relevantes representando a SVMA. Além deles, destaca-se o papel de Miguel Bucalem enquanto presidente do Comitê.

Em diversas entrevistas realizadas o Comitê surgiu como um acontecimento fundamental e fórum permanente ao longo do processo. Para citar apenas duas, Adalberto Maluf, representante do C40 para São Paulo de 2007 a 2014, cita o Comitê como um espaço estratégico dentro da administração municipal, capaz de reunir o primeiro escalão do governo em uma mesa, de legitimar a política climática em construção e, igualmente, de reunir o corpo técnico das diferentes secretarias, de modo a construir diretrizes importantes. Gilberto Natalini, representante do Poder 
Legislativo, também enfatizou em sua entrevista a relevância do Comitê, de tal maneira que este foi um dos pontos que integrou a denúncia que o vereador apresentou ao Ministério Público em 2014, alegando que a gestão do prefeito Haddad descumpria a PMMC/SP, ao, por exemplo, não reunir sequer uma vez o Comitê Municipal até aquele momento.

Dessa forma, é o conjunto de elementos apresentados acima que permite afirmar que Eduardo Jorge foi o mediador da política climática paulistana: “La figure du 'médiateur', qui oint le RGS [rapport global sectoriel], rejoint celle d'autres types de dealers qui, à la croisée des secteurs sociaux et des réseaux d'action publique, articulent une cohérence sociale" (MASSARDIER, 2003, p. 157). Essas qualidades do mediador foram igualmente registradas pela quase unanimidade dos entrevistados.

Mônica Ribeiro, responsável pela comunicação da SVMA, destacou a capacidade de Eduardo Jorge de construir relações e alianças suprapartidárias com seus pares das outras secretarias da administração municipal. Além disso, ela ressaltou a estratégia deliberada de formar alianças com pastas que tivessem peso político e orçamento maior do que a SVMA, como foi o caso de passar a presidência do CMMCE da SVMA para a SDMU.

Stela Goldenstein, que esteve no comando da SVMA de 2001 a 2002, destacou a capacidade de Eduardo Jorge em criar e gerir articulações tanto internamente na Prefeitura quanto com agentes externos. Segundo a entrevistada, Jorge teve a sapiência de compreender a necessidade de se aproximar de especialistas em mudanças climáticas que possibilitassem a formulação de propostas para São Paulo, uma vez que ele próprio tinha conhecimentos mais profundos na área da saúde.

Volf Steinbaum, integrante da equipe da SVMA com participações importantes no programa de inspeção veicular e na secretaria-executiva do CMMCE, afirmou durante a entrevista que as políticas públicas dependem de um grande articulador para que possam ter avanços e que, no caso da política climática na cidade de São Paulo, o principal animador foi Eduardo Jorge.

Hélio Neves, chefe de gabinete na SVMA, já conhecia e se relacionava com Eduardo Jorge desde os tempos da Faculdade de Medicina da USP. Ambos optaram pela medicina sanitarista e, desde o início da vida acadêmica, Hélio começou a participar dos trabalhos do Centro Acadêmico Osvaldo Cruz, aproximando-se, então, do grupo de influência de Eduardo Jorge e do trabalho realizado na zona leste paulistana. Em relação ao que foi realizado durante os oito anos na SVMA, 
Hélio destacou durante a entrevista a "capacidade incomum" de Eduardo Jorge de abrir diálogos com outras áreas e influenciá-las para gerar mudanças comportamentais.

Rachel Biderman, integrante da FGV naquela época e participante da construção do anteprojeto de lei que criou a política de mudança do clima para a cidade de São Paulo, enfatizou a inteligência de Eduardo Jorge em reconhecer que necessitava consubstanciar o trabalho da SVMA na agenda climática em bases cientificas que justificassem e rebatessem as críticas. Mais do que isso, especificamente na condução dos trabalhos junto ao Comitê de Mudança Climática, Biderman destaca a liderança carismática que Jorge exerceu.

Laura Valente, diretora regional do ICLEI, ressaltou durante sua entrevista o trabalho que desenvolveu com as diversas prefeituras no Brasil e demais países da América Latina. Ela ressaltou que, naquela época, havia uma facilidade muito grande em implementar as propostas que o ICLEI trazia, pois os administradores públicos viam aquela parceria como uma oportunidade. Entretanto, Laura relatou que o trabalho com Eduardo Jorge foi diferente de todos os demais, uma vez que Jorge e sua equipe eram proativos nas iniciativas em mudanças climáticas e viam o ICLEI como parceiro estratégico e não como simples oportunidade.

Gilberto Natalini, que viria a ser secretário da SVMA por oito meses durante o ano de 2017, afirmou que um de seus principais objetivos à frente da pasta ambiental foi elevar o patamar da secretaria para o primeiro escalão do governo municipal, assim como havia feito Eduardo Jorge em sua gestão.

Adalberto Maluf, durante a entrevista, relembrou uma conjuntura importante, que demonstra a força político-institucional que Eduardo Jorge construiu especificamente com o prefeito Kassab. Kassab se insere na administração municipal enquanto vice de Serra, após a chapa vencer as eleições de 2004. Após um pouco mais de um ano à frente da Prefeitura, Serra deixa o cargo e abre espaço para que Kassab assumisse a liderança. Até 2008, quando houve novo pleito municipal, Kassab carregava ainda um determinado vínculo com determinadas diretrizes de Serra. Após vencer as eleições de 2008 e assumir ainda maior protagonismo, essa força política gerou impactos na composição das secretarias, momento este em que houve uma quantidade significativa de mudança de posições. Apesar disso, Kassab manteve Eduardo Jorge na SVMA até praticamente os últimos dias de seu mandato. 
Os trechos acima relatados são destacados, portanto, para consubstanciar a conclusão acerca do papel realizado pelo líder-mediador Eduardo Jorge. É importante esclarecer, mais uma vez, que essa liderança gerou resultados unicamente porque estava alicerçada em uma rede de articulações. Essa rede e seus subgrupos elencados aqui, com destaque para as funções de Hélio Neves e Volf Steinbaum, que permitiu que a política climática paulistana lograsse os avanços relatados no capítulo 3 .

As eleições de outubro de 2012 consagraram a vitória a outro grupo político, liderado por Fernando Haddad, que assumiria a administração municipal em janeiro de 2013. Resta saber como interpretar a maneira como a nova gestão tratou dessa agenda.

\subsection{A política climática a partir de 2013}

No capítulo 3 encontra-se a descrição de detalhada dos principais acontecimentos relacionados à política de mudança climática na cidade de São Paulo. Nesta seção desta dissertação já é possível compreender os períodos de maiores avanços e, de outro lado, os períodos em que a agenda sofreu maiores reveses. O capítulo 4 analisou com maior profundidade, até o presente momento, as ideais e valores que contribuíram para a construção da política climática, bem como os atores que estiveram envolvidos nesse processo.

O entendimento a que se chegou é que os anos de 2005 a 2012 foram marcados pela presença de um líder-mediador que foi capaz de construir uma rede de atores que compartilharam um objetivo comum e conseguiram implementar uma série de iniciativas nessa agenda. A investigação científica nesse momento se volta para o período que vai de janeiro de 2013 até dezembro de 2016, quando esse grupo articulado pelo mediador deixou a gestão municipal e outro grupo tomou o poder a partir das eleições de outubro de 2012.

No final do capítulo 2 foram descritos os principais acontecimentos da gestão de Fernando Haddad (PT) em termos de mudanças climáticas. A revisão bibliográfica e as pesquisas em

noticiários e legislações permitem compreender que muitas das iniciativas em curso foram enfraquecidas, outras foram extirpadas e algumas poucas foram criadas. 
O fato é que a política climática enquanto campo próprio e autônomo, capaz de criar sinergias entre setores e implementar mudanças, foi gradativamente enfraquecido, até que deixou de existir. Algumas poucas iniciativas que tiveram impacto positivo, seja em termos de mitigação ou de adaptação, de fato existiram. O principal exemplo foi a política de mobilidade urbana, com incentivos ao transporte público e não motorizado, representando uma significativa vitória do prefeito petista. Entretanto, a "etiqueta" das mudanças climáticas jamais foi evocada. Por que isso aconteceu? As entrevistas realizadas deram algumas pistas que permitem aprofundar a análise.

Assim como os referenciais setorial e global foram os grandes gatilhos para a criação da política climática, esses elementos também estão no centro da justificativa da extinção dessa agenda na gestão municipal paulistana.

Por óbvio, os referenciais do grupo que Haddad e o Partido dos Trabalhadores têm são distintos da rede de política pública que Eduardo Jorge articulou entre os anos de 2005 e 2012. Além dessa alteração e das diferenças político-ideológicas, é importante considerar o poder e a influência do discurso nesse contexto.

O grupo político que venceu as eleições de outubro de 2012 não considerou as mudanças climáticas uma pauta relevante, o que ficou evidenciado desde o programa de governo, os debates eleitorais e a narrativa construída ao longo dos quatro anos de mandato. Ainda que alguns atores desse grupo pudessem concordar com as necessidades de implementar políticas de mitigação e adaptação e que as evidências científicas reforçassem esse entendimento, as ações tomadas e o discurso construído não traçavam essa relação.

Nesse sentido, a interpretação descrita nessa seção e ao final do capítulo 3 desta dissertação encontrou respaldo em praticamente todas as entrevistas realizadas.

Durante a entrevista realizada em julho de 2017, Eduardo Jorge reconheceu que o discurso das mudanças climáticas praticamente desapareceu da administração municipal paulistana a partir de 2013. Entretanto, o entrevistado foi enfático ao afirmar que a gestão de Haddad teve grande sucesso em determinadas políticas que geraram impactos positivos para o combate ao aquecimento global. Entre os exemplos citados estão a política de resíduos sólidos, que o entrevistado reconhece que a gestão de Kassab não teve êxito em lidar, e a política de mobilidade urbana, ancorada em significativos avanços no transporte público com os corredores de ônibus e no transporte não motorizado com os incentivos às bicicletas. 
Laura Valente, por sua vez, entende que agenda climática paulistana resultou de um processo de engajamento contínuo durante doze anos, desde o governo de Marta Suplicy, a partir de 2001, até o final do mandato de Gilberto Kassab, em 2012. Contudo, a entrevistada entende que esse processo foi quebrado a partir do início da gestão de Fernando Haddad, em 2013. Mônica Ribeiro também tem um entendimento similar, ao considerar que a nova gestão quebrou o processo de construção e implementação da política de mudanças climáticas que estava sendo engendrado há anos.

Ao avaliar a gestão Haddad, Stela Goldenstein também entende que a política climática foi em grande parte descontruída. A entrevistada relembrou que, no governo, entre anos de 2013 e 2016, a Ecofrota parou de ser ampliada e sofreu reveses, além da descontinuidade do programa de inspeção veicular - este último havia sido reanimado, com a estruturação do contrato, durante sua gestão em 2001.

Até o próprio Adriano Diogo, integrante do mesmo grupo político que Fernando Haddad, reconhece a importância da política de mobilidade urbana na gestão petista, mas afirma que a política climática foi descontruída, dando como exemplos o fim da inspeção veicular e a ausência de uma política de recursos hídricos.

Fábio Feldmann e Gilberto Natalini também concordam com a interpretação de que a agenda climática perdeu quase que a totalidade de sua força no governo Haddad - com exceção da implantação das ciclovias, sendo um ponto positivo, mas com ressalvas -, com destaque para o fim da inspeção veicular, as ocupações irregulares nas áreas de mananciais e o arrefecimento da implementação dos parques lineares. Ambos chamaram igualmente a atenção para o fato de que na gestão do petista passaram pela SVMA quatro diferentes secretários, de diferentes partidos e sem conexão histórica com a área, o que demonstra a importância dada às questões ambientais naquele governo, entre elas as mudanças climáticas.

Ricardo Young, vereador durante o governo Haddad, também apresentou uma leitura bastante crítica a respeito da postura do poder Executivo em relação à agenda climática. Segundo Young, apesar do programa de governo de Haddad apresentar alguns compromissos com a agenda da sustentabilidade, sua gestão foi um desastre nesse quesito. $\mathrm{O}$ ex-vereador segue em sua análise listando um conjunto de retrocessos, entre eles, o enfraquecimento da pasta ambiental, o fim da inspeção veicular e o não cumprimento da meta de troca da frota de ônibus. $O$ único avanço 
liderado pelo Executivo que Young relata é a criação de duas usinas de reciclagem que, após visitalas, pôde constatar que operavam com uma boa eficiência (ainda que a promessa do governo tivesse sido de criar quatro usinas).

De maneira geral, a avaliação de Young é que no período de 2013 a 2016 a política climática paulistana sofreu grandes retrocessos. O ex-vereador entende que a Câmara Municipal passou então a ser um espaço onde os movimentos ambientalistas encontravam apoio, destacando o papel dos demais colegas vereadores, especialmente, Natalini, Nabil e Aurélio Nomura. Por fim, Young destaca que "Os poucos avanços e os não-retrocessos na pauta da sustentabilidade durante o governo Haddad foram frutos do trabalho do Legislativo".

Adalberto Maluf, em sua entrevista, também compartilhou percepções relevantes em relação à gestão Haddad e suas políticas em termos de mitigação e adaptação. Maluf permite uma leitura diferenciada, uma vez que participou indiretamente, via $\mathrm{C} 40$, de dois momentos diferentes da administração municipal desde 2007, quando Kassab ainda estava em seu primeiro mandato, até 2014, após dois anos de mandato de Haddad.

Em relação ao governo Haddad, Maluf expôs dois comentários, um em relação à visão internacional, e outro em relação aos termos internos de políticas na agenda do clima.

Do ponto de vista da inserção internacional de São Paulo em fóruns internacionais, Adalberto Maluf julga que Haddad tinha pouca sensibilidade a ações desse tipo. Além da própria percepção do prefeito em relação aos fóruns internacionais, Maluf entende que essa realidade também resultou da baixa habilidade do então secretário de relações internacionais, Leonardo Osvaldo Barchini Rosa. Nesse sentido, Maluf destaca que, somente em 2016, último ano de seu mandato, Haddad participou do encontro do C40, que aconteceu na Cidade do México.

Em termos das políticas implementadas por Haddad, Maluf tem uma visão um pouco diferente dos demais entrevistados. O entrevistado reconhece que, ainda que Haddad se negasse a utilizar a bandeira das mudanças climáticas - para o então prefeito as políticas eram sobretudo sociais -, o prefeito petista logrou avanços significativos nas políticas de transporte e resíduos sólidos. Com as políticas de transporte público, aumentando os corredores de ônibus e promovendo as ciclovias, Haddad avançou em termos de política de mitigação, segundo Maluf, uma vez que este é o setor que mais emite GEEs no contexto local. A interpretação de Maluf não é, portanto, 
de todo negativa em relação ao mandato de Haddad, ainda que outros aspectos, como o Comitê Municipal e o C40, tenham perdido muita força.

A partir das entrevistas é possível inferir que a agenda climática havia sido incorporada no imaginário social como uma bandeira vinculada a Eduardo Jorge e seu grupo político por causa do discurso construído e das ações implementadas durante seu mandato. Em função disso, o cálculo político que Haddad e seu grupo fizeram resultou na impossibilidade de usar a mesma bandeira, ainda que, possivelmente, compreendessem a importância da agenda.

Conclui-se, por fim, que os valores que possibilitaram os avanços inicias e a consolidação da política climática paulistana ficaram, em grande parte, restritos à rede construída pelo mediador Eduardo Jorge. Os referenciais que consubstanciaram o entendimento acerca da importância dessa política não foram perenizados e introjetados nem em outros grupos políticos nem na sociedade como um todo. Foram poucos os grupos sociais que demandaram um posicionamento de Fernando Haddad e sua equipe na questão climática. Assim, a consequência foi uma extinção praticamente completa dessa política na gestão municipal paulistana. 


\section{Conclusão}

As mudanças climáticas representam um dos maiores, se não o maior, desafio da humanidade no presente. $\mathrm{O}$ avanço do conhecimento vem gradualmente permitindo compreender esse fenômeno, identificando suas causas, a participação do homem nesse processo e seus impactos a curto, médio e longo prazo. As descobertas da comunidade científica possibilitaram sensibilizar a opinião pública e a percepção dos agentes políticos, o que indica uma chance de enfrentar esse desafio, seja sob o ponto de vista da mitigação de suas causas, seja sob o ponto de vista de adaptação frente a seus impactos.

O próprio conhecimento científico sobre o aquecimento global é recente, com a publicação do primeiro relatório do IPCC em 1990, e ainda está em processo de constante aprendizagem. Mais recente ainda é a tomada de consciência da sociedade global de que se trata de um tema da mais alta relevância. A princípio, a maneira como a política se organizou para tratar do tema se estabeleceu a partir de seus governos nacionais, com suas políticas internas e, especialmente, do âmbito da estrutura de governança criada no sistema internacional, tendo como principais exemplos a UNFCC e as COPs, que tiveram início em 1995.

Paulatinamente, os governos subnacionais começaram a reivindicar uma participação e um protagonismo político nessa agenda, uma vez que seu leque de competências legais permitia contribuir com um conjunto de políticas públicas tanto na adaptação quanto na mitigação da emissão de gases de efeito estufa. Estudar as mudanças climáticas a partir da perspectiva dos governos locais se constitui, por isso, um tema de pesquisa relevante.

Compreender a ação pública paulistana no campo das mudanças climáticas é, nesse sentido, extremamente fundamental. Além do impacto objetivo das emissões de gases de efeito estufa na maior cidade do país, São Paulo exerceu uma liderança e protagonismo importante, tanto na implementação de um conjunto de instrumentos quanto na promulgação de uma legislação específica sobre mudança climática.

A escolha na presente dissertação de considerar o período histórico de quatro mandatos, iniciando em 2001 e terminando em 2016, demonstrou-se acertada, permitindo observar e analisar, com o auxílio do referencial teórico escolhido, como se estabeleceu o processo de construção da política climática paulistana desde os aspectos subjetivos, considerando os valores relacionados a 
essa agenda, identificando os atores-chave, os instrumentos da ação pública implementados e os momentos de avanços e freios até o período recente.

O referencial teórico selecionado também merece uma nota na conclusão deste trabalho. A abordagem cognitiva, os múltiplos atores e os instrumentos da ação pública auxiliaram positivamente na compreensão do fenômeno escolhido para análise e possibilitaram uma leitura aprofundada do caos social e da complexidade da política climática da principal aglomeração urbana do Brasil.

No sentido contrário, o caso selecionado também contribuiu para uma leitura mais crítica das múltiplas teorias que se propõem a analisar as políticas públicas. A política climática paulistana demonstrou que as políticas públicas não se desenvolvem em ciclos, com etapas bem definidas. E foi assim que a Política de Mudança Climática do Município de São Paulo se desenvolveu, a partir de uma construção ao longo do tempo, mas que não necessariamente envolvia um planejamento, execução e avaliação bem detalhados, com ações que ocorriam paralelamente em diferentes áreas, com uma legislação que seria criada somente em 2009 e com objetivos e metas que não foram observados atentamente.

De fato, as primeiras ações no governo municipal de São Paulo relacionadas mais diretamente com os desafios das mudanças climáticas aconteceram no mandato de Marta Suplicy (PT), que esteve à frente da Prefeitura de 2001 a 2004. Naquela época, quando Stela Goldenstein e, em seguida, Adriano Diogo, ocuparam a chefia na SVMA, a cidade de São Paulo começava as tratativas para então contratar a elaboração do $1^{\circ}$ inventário de emissões de gases de efeito estufa do município. Foi também nesse período que São Paulo aderiu ao ICLEI, rede internacional de governos locais para tratar de assuntos relacionados à sustentabilidade e que viria a ser um ator de grande relevância para a construção da política climática paulistana. Já no último ano daquele governo iniciava-se o aproveitamento do biogás do aterro Bandeirantes, o que permitiria no futuro a venda créditos de carbono por parte da cidade no âmbito do Mecanismo de Desenvolvimento Limpo (MDL), criado a partir das negociações internacionais que resultaram no Protocolo de Kyoto em 1997. Apesar desses avanços, nesse momento as mudanças climáticas ainda não haviam constituído um campo autônomo e independente dentro do governo local de São Paulo.

Em 2005 assumia a prefeitura José Serra (PSDB), político que fazia oposição ao governo e ao partido da então ex-prefeita Marta Suplicy. Serra escala Eduardo Jorge (PV), ex-Secretário 
Municipal de Saúde e recém ex-filiado ao PT, para liderar os trabalhos na SVMA. Desde o início do ciclo que se iniciaria, Serra orienta todas as demais pastas da administração municipal a trabalhar em conjunto com a SVMA e, ao mesmo tempo, fortalece e legitima o papel de Eduardo Jorge no governo. A partir daquele momento, Jorge passaria a exercer o cargo mais longevo na pasta ambiental da cidade, mantendo-se na SVMA até 2012.

Com a saída de Serra do governo em 2006, cerca de um ano após assumir o cargo, seu vice, Gilberto Kassab (PFL), assume o comando da cidade e mantém Jorge na SVMA. Kassab exerceria o cargo de prefeito durante onze anos consecutivos, vencendo uma eleição em 2008. Durante sua gestão, além de manter Jorge na pasta ambiental e seguir com a diretriz para que as demais secretarias trabalhassem em parceria com esta, Kassab fortaleceu a SVMA, inclusive sob o ponto de vista orçamentário.

Nesse período de 2005 a 2012 a Secretaria do Verde e Meio Ambiente exerceria a liderança na agenda climática local. Essa característica era o reflexo da postura do próprio secretário Eduardo, Jorge que viria a se constituir como o principal agente da política climática paulistana, classificado como mediador, segundo à nomenclatura da abordagem teórica adotada. Nesse ponto, mais uma reflexão teórica merece destaque. As nomenclaturas e classificações que as produções teóricas fornecem auxiliam na compreensão dos fatos, mas merecem parcimônia e criticidade ao serem utilizadas, pois o caso paulistano demonstrou que há uma dificuldade em "enquadrar" os atores segundo as definições impostas pela literatura.

A liderança intelectual e política de Eduardo Jorge permitiu que as mudanças climáticas passassem a representar o principal "guarda-chuva" de políticas públicas, encampando ações desde a esfera educacional, a construção civil até os transportes. Grande parte das ações implementadas nesse período só foi possível porque Jorge teve a capacidade de construir uma rede de colaboradores, trabalhando em conjunto com as demais secretarias, envolvendo atores da sociedade civil e da academia e participando de redes internacionais.

Do ponto de vista dos instrumentos da ação pública, houve um conjunto deles, de diferentes naturezas, que contribuiu para o avanço da política de mudanças climáticas no município de São Paulo, desde instrumentos econômicos como o MDL e os orçamentos das secretarias aos instrumentos de participação e integração, como o Comitê de Mudança do Clima e Economia, o inventário de emissões como instrumento de planejamento, entre tantos outros. 
Entre os diferentes instrumentos, é importante relembrar a importância da Lei 14.933, de 5 de junho de 2009, que institucionalizou a Política Municipal de Mudança do Clima. A partir dessa legislação o município de São Paulo legitimou e cristalizou seu protagonismo na agenda climática, antecipando-se em relação ao governo estadual de São Paulo e ao governo federal. A temporalidade da promulgação dessa lei, de modo que o município de São Paulo criou uma política climática antes do Estado brasileiro e do estado de São Paulo é reflexo de uma competição multinível implícita que merece ser investigada, a partir dessa abordagem, com maior profundidade.

Somado a isso, a legislação paulistana foi inovadora ao incorporar metas específicas para o cumprimento da pauta climática na cidade, entre elas a redução de $30 \%$ nas emissões de GEEs até 2012 e a substituição integral da frota de ônibus para um modelo de combustível renovável não-fóssil até 2018.

Diferentes ações foram implementadas, correlacionadas a diferentes políticas setoriais, com importante contribuição para o campo climático. Para mencionar apenas alguns deles, houve o aproveitamento energético nos aterros sanitários, com a venda de créditos de carbono no mercado internacional; o Programa Ambientes Verdes e Saudáveis, com agentes de saúde; a divulgação da Carta da Terra nas escolas da rede municipal; a aprovação de lei que obrigava as novas edificações a terem equipamentos de aquecimento solar; a inspeção veicular para controle de poluentes; os parques municipais criados que aumentaram a cobertura verde da cidade; e a Ecofrota, com a substituição da frota de ônibus por modelos com utilização de combustível de fonte renovável.

Durante esse período de 12 anos foi possível identificar, ao resgatar os documentos existentes e ao realizar as entrevistas, a importância da perspectiva internacional e seus impactos na realidade local. O contexto internacional prévio aos anos 2000 contribui ao divulgar as descobertas cientificas a respeito das mudanças climáticas, ao construir um campo de valores relacionados a esse tema e ao sensibilizar a sociedade, de modo que a partir de 2005 foi possível defender essa agenda na gestão municipal de São Paulo. Os acontecimentos internacionais também impactaram no desenvolvimento das ações em São Paulo, como as negociações durante a COP em Copenhagen, em 2009, e a votação na Câmara Municipal sem grandes dificuldades para aprovar a criação da PMMC. Os fóruns e as viagens internacionais também permitiram que a administração paulistana conhecesse as experiências de outras cidades, ao mesmo tempo que serviam de 
plataforma para divulgar os avanços internos, a exemplo do que fez a Prefeitura no encontro do C40 em São Paulo em 2011.

Em 2013, Fernando Haddad (PT) iniciou seu mandato como prefeito de São Paulo. A partir de então as mudanças climáticas perderam força e a SVMA perdeu seu protagonismo. Durante essa gestão passaram pela pasta ambiental três diferentes secretários, com pouca experiência no campo. O Comitê deixou de se reunir por um longo período de tempo e houve alguns retrocessos, a exemplo do fim da inspeção veicular. Apesar de alguns avanços na implantação de ciclovias e ciclofaixas, além da expansão dos corredores de ônibus, a "bandeira" das mudanças climáticas deixou completamente de existir. É possível notar nesse período um deslocamento do protagonismo do Poder Executivo na pauta climática para o Poder Legislativo, com a atuação da Frente Parlamentar pela Sustentabilidade e as reivindicações de vereadores como Gilberto Natalini (PV).

A análise da política climática de São Paulo ao longo deste período possibilitou compreender que existe uma dependência muito forte entre o avanço de determinada agenda e a atividade do mediador daquela política pública. O desafio de perenizar determinada agenda por um período longo e entre atores de grupos políticos diferentes depende da superação dessa dependência com determinado ator a partir do compartilhamento dos valores e ideais que consubstanciam determinada política pública. Foi exatamente o que aconteceu com São Paulo, onde, a partir do momento que o mediador da política climática e a rede de política que se formatou deixaram o governo, a agenda climática perdeu força e se desestruturou.

A presente dissertação se encerra, por fim, com o desejo de ter contribuído, dentro de suas limitações, para o avanço do campo da Ciência Ambiental, lançando um olhar interdisciplinar para a complexidade das relações sociais e da produção de políticas públicas. Espera-se, igualmente, ter contribuído no campo teórico, ao resgatar e utilizar com criticidade importantes referenciais. Além disso, este autor tem a expectativa de ter resgatado com seriedade e fidelidade um importante período da história política da cidade de São Paulo, registrando as iniciativas de uma megacidade ao enfrentar um desafio de proporções ainda desconhecidas, como as mudanças climáticas. 
6. Referências bibliográficas

ALVES SOBRINHO, Eduardo Jorge Martins. Três ou quatro sementes de araçá: coletânea de artigos de Eduardo Jorge Martins Alves Sobrinho (2005 a 2012). Organização de Mônica C. Ribeiro e Volf Steinbaum. São Paulo: Conteúdo \& Afins, 2013.

ANGELO, Claudio. A espiral da morte: como a humanidade alterou a máquina do clima. São Paulo: Companhia das Letras, 2016.

ÁVILA, Mário Lúcio de. Ação pública territorializada de desenvolvimento rural: o caso do território das águas emendadas. Tese (Doutorado) - Universidade de Brasília, Centro de Desenvolvimento Sustentável, Brasília: 2011.

BACK, A. G. Política climática paulistana: agenda em contínuo aprimoramento. Dissertação (Mestrado) - Universidade Federal de São Carlos, Programa de Pós-Graduação em Ciência Política, São Carlos: 2012.

Agenda climática no município de São Paulo: contribuição das redes transnacionais de governos locais. Teoria \& pesquisa v. 21, n. 2, p. 97-107, jul/dez. 2012.

BALAZINA, Afra. Prefeitura exige compensação por Rodoanel. Folha de São Paulo. Disponível em: <http://www1.folha.uol.com.br/fsp/cotidian/ff0609200510.htm>Acesso em: 10 jul. 2017.

BBC Brasil. Marta Suplicy vai presidir a ONU das cidades: Disponível em: $<$ http://www.bbc.com/portuguese/noticias/story/2004/05/printable/040503 martams.shtml $>$ .Acesso em: $10 \mathrm{dez} 2016$

BETSILL, Michele M. e BULKELEY, Harriet. Cities and the multilevel governance of global climate change. Global governance, 2006.

BHASKAR, R. et al. Interdisciplinarity and climate change. Oxford: Routlege, 2010.

BULKELEY, Harriet e BETSILL, Michele M. Cities and climate change, 2003. 
CALDAS, E. L.; MOREIRA, I. Políticas de desenvolvimento territorial e intermunicipalidade no Brasil: complementaridades e tensões. Sustentabilidade em Debate, Brasília, v. 4, n. 2, p. 41-61, jul. /dez. 2013.

CÂMARA MUNICIPAL DE SÃO PAULO. Decreto Municipal nº 49.463, de 30 de abril de 2008. Dispõe sobre o Programa de Inspeção e Manutenção de Veículos em Uso - I/M-SP: Disponível em: $<$ http://www3.prefeitura.sp.gov.br/cadlem/secretarias/negocios juridicos/cadlem/integra.asp? alt $=30042008 \mathrm{D} \% 20494630000>$ Acesso em: 10 jan. 2016

. Decreto Municipal no 50.886, de 21 de setembro de 2009. Dispõe sobre as competências, a composição e o funcionamento do Comitê Municipal de Mudança do Clima e Ecoeconomia.

. Justificativa PL 167/2015: Disponível em:

$<\underline{\text { http://documentacao.camara.sp.gov.br/iah/fulltext/justificativa/JPL0167-2015.pdf }>\text { Acesso em }}$ 10 jan. 2016

CAMPOS, Paulo Prado de Sousa Campos. Gestão integrada de políticas públicas relacionadas às mudanças climáticas na região metropolitana de São Paulo. Tese (Doutorado) Universidade de São Paulo, Faculdade de Saúde Pública, São Paulo: 2014.

CLIMATE Action in Megacities 3.0: networking works, there is no global solution without local action. C40 Cities. ARUP, 2015.

COMEÇA em 15 dias reforma da marginal Tietê. Folha de São Paulo Disponível em: $<$ http://www.agora.uol.com.br/saopaulo/ult10103u576871.shtml $>$ Acesso em 10: 10 jul. 2017.

COMITÊ Municipal de Mudança do Clima e Ecoeconomia. Atas de todas as reuniões: $<$ http://www.prefeitura.sp.gov.br/cidade/secretarias/meio ambiente/comite do clima/atas do c onselho/index.php? $\mathrm{p}=15108>$ Acesso em: 10 jul. 2017

COMITÊ Municipal de Mudança do Clima e Ecoeconomia . Contratação de serviços de consultoria para elaboração de inventário municipal de emissões e remoções antrópicas de gases de efeito estufa (GEE) e outros produtos, no município de São Paulo, apresentação feita em 20 de outubro de 2011: Disponível em:

$<$ http://www.prefeitura.sp.gov.br/cidade/secretarias/upload/chamadas/apres patricia $20 \quad 10 \quad 11$ 1320937643.pdf>. Acesso em: 10 jul. 2017. 
COMPACT OF MAYORS. Disponível em: $<$ http://www.compactofmayors.org $>$. Acesso em 10 jul. 2017.

CORTESE, Tatiana Tucunduva Philippi. Mudanças climáticas na cidade de São Paulo: avaliação da política pública municipal. Tese (Doutorado), Universidade de São Paulo, Faculdade de Saúde Pública, São Paulo: 2013.

CROZIER, Michel e FRIEDBERG, Erhard. L'acteur et le système: les contraintes de l'action collective. Editions du Seuil, Paris, 1977.

DIÁRIO DO PAVS: Disponível em: < http://diariodopavs.blogspot.com.br/> Acesso em: 10 jul. 2018.

EDUARDO Jorge. Disponível em: <. http://www.eduardojorgepv.com.br $>/$. Acesso em: 10 jul 2017.

ENTREVISTA de Eduardo Jorge. Revista Página 22, maio, 2012. Disponível em:

<file://C:/Users/Adm/Downloads/29343-54423-1-PB.pdf > Acesso em : 20 jul. 2017.

ERICKSON, Peter e TEMPEST, Kevin. Advancing climate ambition: How city-scale actions can contribute to global climate goals. Stockholm Environment Institute, working paper no. 201406.

GERAQUE, Eduardo. Plano climático de SP quer reduzir emissão de gases em 30\%”. Folha de São Paulo Disponível em: <http://www1.folha.uol.com.br/fsp/cotidian/ffl408200802.htm> Acesso em: 10 jul. 2017.

GERAQUE, Eduardo . TCM suspende licitação e nova inspeção pode ficar para 2015. Folha de São Paulo. Disponível em: http:/www1.folha.uol.com.br/cotidiano/2014/05/1455196-tcmsuspende-licitacao-e-nova-inspecao-pode-ficar-para-2015.shtml. Acesso em: 10 jul. 2017.

FURRIELA, Rachel Biderman. Limites e alcances da participação pública na implementação de políticas subnacionais em mudanças climáticas e o município de São Paulo. Tese (Doutorado) -Fundação Getúlio Vargas, Escola de Administração de Empresas, São Paulo: 2011. 
FRIEDBERG, Erhard. Le Pouvoir et la Règle. Dynamiques de l'action organisée. Seuil, 1993.

GIDDENS, Anthony. A política da mudança climática. São Paulo: Zahar, 2010.

HALL, Peter A.; TAYLOR, Rosemary C. R. Political Science and the three new institutionalisms. MPIFG Scientific Advisory Board. Cambridge, 1996.

INSPEÇÃO veicular em São Paulo. Folha de São Paulo. Disponível em:

$<$ http://www.prefeitura.sp.gov.br/cidade/secretarias/meio ambiente/comite_do_clima/noticias/?p $=15472>$ Acesso em 10 jul. 2017.

INSTITUTO DE PESQUISAS DATAFOLHA. Mudanças climáticas: o que pensa o brasileiro. Maio de 2015.

INTERGOVERNMENTAL PANEL ON CLIMATE CHANGE. Summary for Policymakers. In: Climate Change 2014: Mitigation of Climate Change. Contribution of Working Group III to the Fifth Assessment Report of the Intergovernmental Panel on Climate Change [Edenhofer, O., R. Pichs-Madruga, Y. Sokona, E. Farahani, S. Kadner et al., K. Seyboth, A. Adler, I. Baum, S. Brunner, P. Eickemeier, B. Kriemann, J. Savolainen, S. Schlömer, C. von Stechow, T. Zwickel and J.C. Minx (eds.)]. Cambridge University Press, Cambridge, United Kingdom and New York, NY, USA.

KAHN, Suzana ; BRANDÃO, Isabel. The contribution of low-carbon cities to Brazil's greenhouse gas emissions reduction goals: briefing on urban energy use and greenhouse gas emissions. Stockholm Environment Institute e Universidade Federal do Rio de Janeiro (UFRJ), 2015.

KASSAB participa leilão de crédito de carbono em SP. O Estado de São Paulo, São Paulo, 25 set. 2008. Disponível em: <http://politica.estadao.com.br/noticias/eleicoes,kassab-participaleilao-de-credito-de-carbono-em-sp,248137> Acesso em 10 jul. 2017.

KINGDON, J. Agendas, alternatives and public policies. Boston: Little Brown, 1984.

LANDIN, Rubens. Mudanças climáticas, impactos urbanos e a capacidade de adaptação: um estudo crítico sobre a inserção do Setor Saúde na Política de Mudança do Clima do Município de 
São Paulo. Dissertação (Mestrado) - Universidade de São Paulo, Faculdade de Saúde Pública, São Paulo: 2013.

LASCOUMES, Pierre e LE GALÈS, Patrick. A ação pública abordada pelos seus instrumentos. Dossiê, Revista UFMA, 2012.

Conclusion: de l'inovation instrumentale à la recomposition de l'Etat. In: Gouverner par les instruments, Presses de Sciences Po, 2005, p. 357-370. 2011.

. L'action publique au prisme de ses instruments. Presses de Sciences Po, v. 61, p. 5-22.

LASSWELL, Harold. The Decision Process: Seven Categories of Functional Analysis. College Park, Maryland: University of Maryland Press, 1956.

LEITE, Fabiane. Eduardo Jorge deixa Secretaria da Saúde e retorna à Câmara. Folha de São Paulo. Disponível em: $<$ http://www1.folha.uol.com.br/fsp/cotidian/ff0612200215.htm $>$ Acesso em 10 jul. 2017

MARTINS, Rafael D'Almeida e FERREIRA, Leila da Costa. Opportunities and constraints for local and subnational climate change policy in urban areas: insights from diverse contexts. Int. Global Environmental Issues, v. 11, n. 1, 2011.

MASSACHUSETTS InSTITUTE OF TECHNOLOGY. Joint Program on the Science and Policy of Global Change. Food, Water, Energy \& Climate Outlook. Cambridge, 2016.

MASSARDIER, G. Politiques et action publiques. Paris: Armand Colin, 2003.

MASSADIER, Gilles. Cognição, políticas e ações públicas: entre coerência, fragmentação e aprendizados" IN BONNAL, P. e LEITE, S. (Org). Análise comparada de políticas agrícolas: uma agenda em transformação”. Rio de Janeiro: Mauad X, 2011.

MATIAS, Eduardo Felipe P. A humanidade contra as cordas. São Paulo: Paz e Terra 2014.

MERCHANTS OF DOUBT. Direção: Robert Kenner, Local: Estados Unidos da América, 2014, Produtora: Participant Media. 
MULLER, Pierre. Politiques publiques. Paris: PUF, 2003 [1990].

MULLER, Pierre. Esquisse d'une théorie du changement dans l'action publique. Revue française de science politique, Presses de Sciences Po, v. 55, p. 155-187, 2005.

NOBRE, C. A. et al. Vulnerabilidade das megacidades brasileiras às mudanças climáticas: região metropolitana de São Paulo. Junho de 2010.

OSTROM, Elinor. A polycentric approach for coping with climate change. World Development Report, 2009.

Green from the grassroots. Project Syndicate, 2012

PALIER, Bruno e SUREL, Yves. Les trois i et l'analyse de l'état en action. Revue française de science politique. Sciences Po, 2005.

PLANO de Governo Fernando Haddad, eleições municipais de São Paulo em 2012. Disponível em: $<$ https://jornalggn.com.br/sites/default/files/documentos/programa_de_governo_haddad.pdf $>$. Acesso em 10 set 2017.

POR um transporte menos poluente em SP. Folha de São Paulo. Disponível em: $<$ http://www1.folha.uol.com.br/fsp/opiniao/fz1512201008.htm> Acesso em: 10 jul.2017 PORTAL da Prefeitura de São Paulo. Prefeitura arrecada R \$ 4,5 milhões em leilão de Créditos de Carbono: Disponível em :

$<\underline{\text { http://www.prefeitura.sp.gov.br/cidade/secretarias/comunicacao/releases/?p=142021 }>\text {. Acesso }}$ em: 10 set 2017 .

PREFEITURA DE SÃO PAULO. Para entender o desenvolvimento sustentável. São Paulo: Editoria 34, 2015. Diário Oficial do Município de São Paulo, 20 maio 2004. Disponível em: $<\underline{\mathrm{http}}$ //www.docidadesp.imprensaoficial.com.br/NavegaEdicao.aspx?ClipId=6EBGMMDC1EF M1e46PS76F145T28> Acesso em: 20 jun. 2018.

Diretrizes para o plano de ação da cidade de São Paulo para mitigação e adaptação às mudanças climáticas. Elaborado pelo Comitê Municipal de Mudança do Clima e Ecoeconomia 
e Grupos de Trabalho de Transporte, Energia, Construções, Uso do Solo, Resíduos e Saúde. Maio de 2011.

- Secretaria Municipal do Verde e Meio Ambiente de São Paulo. Inventário de Emissões de Gases de Efeito Estufa do Município de São Paulo. Julho de 2005.

. Secretaria Municipal do Verde e Meio Ambiente de São Paulo. Inventário de Emissões e Remoções Antrópicas de Gases de Efeito Estufa do Município de São Paulo de 2003 a 2009, com atualização para 2010 e 2011 nos setores de Energia e Resíduos. Novembro de 2013.

Secretaria Municipal do Verde e Meio Ambiente de São Paulo. Lei n⿳0 14.933, de 5 de junho de 2009.

Secretaria Municipal do Verde e Meio Ambiente de São Paulo. Edital de concorrência para o programa de inspeção veicular. Disponível em:

$<$ http://www.prefeitura.sp.gov.br/cidade/secretarias/upload/meio ambiente/arquivos/edital\%20pr ograma\%20inspecao.pdf $>$. Acesso em: 10 set 2017.

Climáticas:

Plano de Ação da cidade de São Paulo para Mitigação e Adaptação às Mudanças

$<$ http://www.prefeitura.sp.gov.br/cidade/secretarias/upload/chamadas/apresenta170211 plano d e_acao_mudancas_climaticas_com_as_contribuicoes_de_todos_os_gts_1299847549.pdf> Acesso em: 10 set 2017.

PREFEITURA DE SÃO PAULO. Prefeitura transfere mais de 4 mil famílias de áreas de risco. Disponível em:

$<$ http://www.prefeitura.sp.gov.br/cidade/secretarias/comunicacao/releases/?p=141736>. Acesso em: 10 jan. 2017.

. DECRETO No 45.959, DE 6 DE JUNHO DE 2005. Cria o Comitê Municipal sobre Mudanças Climáticas e Ecoeconomia Sustentável: Disponível em:

$<$ http://www3.prefeitura.sp.gov.br/cadlem/secretarias/negocios juridicos/cadlem/integra.asp?alt $=07062005 \mathrm{D} \% 20459590000>$. Acesso em: 10 set. 2018 . 
$<$ http://www.prefeitura.sp.gov.br/cidade/secretarias/meio_ambiente/comite_do_clima/c40/impre nsa/index.php? $\mathrm{p}=47756>$. Acesso em: 10 ago. 2017.

RAMIRES, J. Z. dos S. Políticas Públicas, Mudanças Climáticas e Riscos em São Paulo. Tese (Doutorado) - Universidade de São Paulo, Faculdade de Filosofia, Letras e Ciências Humanas, Departamento de Geografia. São Paulo, 2015.

REDE NOSSA SÃO PAULO. Emissão de poluentes cresce $\mathbf{7 , 2} \%$ e SP não cumpre lei. Disponível em: $<$ http://www.nossasaopaulo.org.br/noticias/emissao-de-poluentes-cresce-72-e-spnao-cumpre-lei $>$. Acesso em: 10 set. 2017.

Prefeitura de SP regulamenta lei de aquecedores solares, mas cede parcialmente a lobby contrário: Disponível em: < http://www.nossasaopaulo.org.br/portal/node/200>. Acesso em: 10 set. 2017.

Principais metas da Lei de Mudança do Clima de São Paulo não estão sendo cumpridas. Disponível em: <http://www.nossasaopaulo.org.br/noticias/principais-metas-da-leide-mudanca-do-clima-de-sao-paulo-nao-estao-sendo-cumpridas>. Acesso em 10 set. 2017.

SABATIER, P. A. An Advocacy Coalition Framework of policy change and the role of policyoriented learning therein. Policy Sciences, 21, n. 2-3, p. 129-68, 1988.

Knowledge, Policy-oriented Learning, and Policy Change. Knowledge, v. 8, n. 4, 1987.

et al. (Ed.). Policy Change and Learning, an Advocacy Coalition Approach. Boulder,

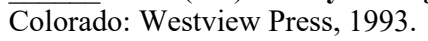

SAFATLE, Amália. Um mandato em quatro atos. São Paulo: 1 ed. dez. 2016.

SANGIOVANNI, Ricardo. Aluguel de bicicletas começa hoje em 4 estações do Metrô. Folha de São Paulo. Disponível em :< http://www1.folha.uol.com.br/fsp/cotidian/ff2709200838.htm>

Acesso em: 10 jul. 2016. 
SECRETARIA ESTADUAL DE MEIO AMBIENTE. O licenciamento Ambiental do Rodoanel. Disponível em: < http://www.ambiente.sp.gov.br/rodoaneltrechosul/licenciamento/>. Acesso em: 10 jul. 2017.

SERRA deixa cargo hoje para se candidatar. Folha de São Paulo. Disponível em: $<$ http://www1.folha.uol.com.br/fsp/brasil/fc3103200618.htm> Acesso em: 10. Jul. 2017.

TOLY, Noah J. Transnational municipal networks in climate politics: from global governance to global politics. Globalizations, 2008.

UNITED NATIONS, Department of Economic and Social Affairs, Population Division . World Urbanization Prospects. 2014.

U.S. GLOBAL CHANGE RESEARCH PROGRAM. Climate Science Special Report: Fourth National Climate Assessment. Washington, 2017.

POR 2016, Haddad dá posse a secretário do PR. Veja. Disponível em: $<$ http://veja.abril.com.br/politica/por-2016-haddad-da-posse-a-secretario-do-pr/> Acesso em: 10 jun. 2018.

VEIGA, José Eli da A desgovernança mundial da sustentabilidade. São Paulo: Editora 34, 2013.

WEBER, Max. Ciência e política: duas vocações. $2^{\mathrm{a}}$ ed., Martin Claret. 1919.

ZANCHETTA, Diego. PT vence disputa com comunistas e ganha Secretaria do Verde. O Estado de São Paulo, São Paulo, 18 fev. 2014. Disponível em: <http://saopaulo.estadao.com.br/blogs/diego-zanchetta/pt-vence-disputa-com-comunistas-e-ganhasecretaria-do-verde/> Acesso em 10 set 2017. 
7. Notas metodológicas

Esclarecer o caminho percorrido durante o processo de construção desta dissertação é central, uma vez que permite ao leitor compreender em detalhes como o autor conseguiu sair do ponto de inércia até alcançar o ponto final desta investigação científica, esmiuçando as estratégias e dificuldades encontradas. Deste modo, esse capítulo é dedicado a explicar as diferentes etapas da pesquisa, desde a definição do tema, o estudo de caso, a escolha do referencial teórico, o que ficou de fora do escopo definido, as pesquisas e entrevistas ${ }^{6}$. Desde o princípio o leitor deve ter claro que, apesar dos passos metodológicos serem apresentados aqui como etapas sequenciais, o processo de pesquisa dificilmente é linear e rígido, e que portanto acontecem de maneira bastante dinâmica durante o transcorrer de sua elaboração.

As trajetórias do autor e do orientador tiveram impacto significativo no desenvolvimento desta dissertação. De um lado, o autor tem uma formação acadêmica em relações internacionais, o que lhe nutriu interesse específico nas negociações internacionais relacionadas à clima. Por outro lado, sendo uma formação fortemente interdisciplinar e, mais especificamente, voltada às questões de ciência social e política, também contribuiu para que houvesse interesse em investigar como as políticas públicas são construídas e o relacionamento entre os atores envolvidos em determinado processo, especialmente na cidade natal do autor. Ademais, a atuação profissional do autor num instituto de pesquisa voltado a políticas públicas (Instituto Democracia e Sustentabilidade - IDS), sendo uma ONG com relações próximas a academia e a diversos agentes políticos, também representaram fatores que influenciaram tanto na escolha da temática quanto na decisão de aprofundar a formação acadêmica.

Em relação ao orientador, destaca-se o fato de que já esteve nos dois lados do "balcão", atuando tanto como analista e pesquisador de políticas públicas e enquanto agente político implementador de políticas públicas. Especialmente em relação a sua atuação acadêmica, é importante apontar sua importante contribuição no que se refere às teorias de análise de políticas públicas, fator que foi muito relevante para o desenvolvimento desta produção acadêmica, como pretende se demonstrar ao longo desta leitura.

\footnotetext{
${ }^{6}$ O capítulo metodológico da tese de doutorado de Mário Lúcio de Ávila foi considerada como referência para o desenvolvimento do presente capítulo.
} 
Assim, vale destacar que, ainda que os erros e acertos do conteúdo aqui descrito sejam de responsabilidade do próprio autor, o processo de definição do objeto de estudo e as aprendizagens de que dele decorrem são frutos de uma relação de troca muito ativa entre o orientado e o orientador.

O pressuposto preliminar que orientou as demais decisões foi a vontade, além da importância, de trabalhar com a relação entre governos locais e mudanças climáticas. Sem dúvidas, o tema das mudanças climáticas está na pauta e, para um pesquisador que trabalha diariamente com o escopo da sustentabilidade, o que por si só reforça a necessidade de que seja tratado pela academia em suas diversas abordagens, sobretudo com um olhar interdisciplinar. O tema das mudanças climáticas foi sendo "consumido" por esse autor e assumido como imprescindível de ser tratado a partir da leitura de várias obras, tais como Nobre et al. (2010), Giddens (2010), Matias (2014) e Da Veiga (2015).

Somada às reflexões propostas por estes autores juntou-se a leitura de diversas produções acadêmicas, as quais chamam a atenção para a necessidade de que os desafios impostos pelo aquecimento global sejam tratados a partir do olhar, das competências e do alcance dos governos locais. Destacam-se aqui os trabalhos de Ostrom (2009) e Martins e Ferreira (2011), já mencionados na introdução deste trabalho, que tiveram importante relevância no momento inicial da pesquisa e que, portanto, vale a pena serem ressaltados novamente. Ostrom (2009) estabelece seu raciocínio a partir do conceito de "governança policêntrica", considerando que a participação dos governos locais deve ter maior relevância na construção de políticas sobre mudanças climáticas. Martins e Ferreira (2011) identificam, a partir de revisão da literatura, três maneiras como as mudanças climáticas estão relacionadas com as cidades: a maioria das emissões de gases de efeito estufa provém das cidades e portanto está aí a maior necessidade de políticas de mitigação; os impactos das mudanças climáticas serão sentidos sobretudo nos grandes centros urbanos, sendo portanto necessário o desenvolvimento de políticas de adaptação; a existência de uma série de sinergias entre as políticas de desenvolvimento sustentável urbano e as políticas relacionadas às mudanças climáticas. Assim, desde o início autor e orientador estavam de acordo da necessidade de se trabalhar na perspectiva dos governos locais e suas políticas públicas voltadas às mudanças climáticas.

Então, partindo do pressuposto inicial de trabalhar com mudanças climáticas e governos locais, o desafio se concentrou em definir se o estudo abrangeria somente uma única experiência 
ou não. Desde então, o município de São Paulo apontou como um caso que não poderia ser descartado por diversos motivos. A cidade paulistana é a maior cidade do Brasil, uma das maiores aglomerações do mundo e, além disso, local de residência do autor e um processo que o orientador acompanhou de perto. Além disso, São Paulo foi protagonista na aprovação de uma legislação municipal que tratasse propriamente das mudanças climáticas, a partir da Lei $n^{\circ} 14.933$, de 5 de junho de 2009 (antes mesmo da Política Nacional e da Política Estadual).

Vale a pena descrever minimamente em qual contexto internacional, nacional e estadual, e como isso justificou a relevância do caso paulistano. Apesar de no âmbito do sistema internacional o arranjo e as negociações sobre as mudanças climáticas existirem desde pelo menos a Rio 92, com a assinatura do tratado conhecido como Cúpula da Terra (1992), até o ano de 2009 o Brasil não contava com uma legislação nacional que versasse sobre o tema. É nesse contexto que surge o protagonismo do município de São Paulo ao promulgar em 5 de junho de 2009 sua política municipal, a qual representa a primeira legislação no território nacional sobre mudanças climáticas (PMMC). A importância desse processo foi de tamanha grandeza que influenciou o Estado de São Paulo, que promulgou sua própria lei sobre mudanças climáticas (PEMC) em novembro do mesmo ano (5 meses após a cidade), e o governo federal ao promulgar em dezembro também do mesmo ano (6 meses após a cidade de São Paulo) a política nacional sobre mudanças climáticas (PNMC).

Assim, restava avançar sobre a definição e possível inclusão de outra experiência em nível local e, assim, foi considerado o município de Belo Horizonte. A cidade mineira é um dos maiores do País em termos de população, tendo assim uma relevância em termos de emissão de GEEs, além de ter criado seu Comitê Municipal sobre mudanças climáticas em 2006 e instituído sua política municipal de mudanças climáticas alguns anos após São Paulo, em maio de 2011. Outro fato relevante que foi descoberto sobre Belo Horizonte é sua participação no Iclei desde 1993, sendo um dos membros mais antigos. Como o Iclei teve uma participação relevante no processo paulistano, imaginou-se que esse era um fator relevante para considerar Belo Horizonte na pesquisa.

Não obstante, em pouco tempo essa opção foi desconsiderada por alguns motivos. Em primeiro lugar, as pesquisas preliminares demonstraram a existência de uma enorme dificuldade em encontrar informações sobre o caso, tais como produções acadêmicas, notícias de jornais, informações oficiais no site da prefeitura e da câmara municipal. Em segundo lugar, o caso de Belo Horizonte não representou o mesmo protagonismo que a cidade de São Paulo, dado que sua 
política municipal foi instituída somente após a própria PNMC. Além destas justificativas, autor e orientador chegaram ao entendimento de que o caso de São Paulo já era demasiadamente complexo e que, juntamente com o processo de entrevistas, as distâncias territoriais iriam dificultar demasiadamente, sobretudo considerado o curto prazo de dois anos para o processo de mestrado.

Tomada a decisão de que a pesquisa se concentraria no estudo de caso único da cidade de São Paulo foi realizada uma revisão não sistemática da produção acadêmica a respeito deste caso, identificando assim quatro teses de doutorado (FURRIELA, 2011; CORTESE, 2013; CAMPOS, 2014; RAMIRES, 2015) e duas dissertações de mestrado (BACK, 2012; LANDIM, 2013). As áreas de concentração dessas cinco produções acadêmicas se dividem em três na saúde pública, uma em ciência política e uma em administração pública.

Ainda que todas as produções sejam relativamente recentes, nota-se que há cerca de quatro anos não há nenhuma nova produção acadêmica que investigou o caso da política municipal de São Paulo sobre mudanças climáticas, o que abre uma janela de oportunidade para a presente dissertação.

A leitura e análise dessas produções acadêmicas permitiu compreender quais as lacunas existentes, as possibilidades de abordagem sobretudo em termos teóricos e como este autor poderia contribuir para o avanço do campo da ciência ambiental.

Após a opção pela via do caso único e da compreensão de quais são as produções acadêmicas que abordam um momento similar da vida política paulistana, o desenvolvimento desta dissertação se voltou para a definição de qual seria a cronologia a ser objeto do estudo. Para isso foram feitas pesquisas em notícias, sites oficiais e na própria produção acadêmica supracitada e, então, decidiu-se pelo recorte temporal iniciando em 2001 com o mandato da então Prefeita Marta Suplicy (PT), passando pelo mandato de José Serra (PSDB)/Gilberto Kassab (PFL/DEM) no período de 2005 a 2012 e terminando no mandato de Fernando Haddad (PT), em 2016.

O recorte temporal selecionado se justifica pelos seguintes motivos: ao final do mandato de Marta Suplicy foi contratado um instrumento de suma importância para a construção da política municipal sobre mudanças climáticas, o Inventário de Emissões, disponibilizando um diagnóstico detalhado da situação da cidade; o mandato Serra/Kassab, com a reeleição para mais um mandato em 2008, foi central para o caso estudado, uma vez que foi nesse período em que foi instituída de fato no ordenamento jurídico do município uma política pública sobre mudanças climáticas; e o 
mandato de Fernando Haddad, por ter sido o último, por não ter sido objeto de análise de nenhuma das outras produções acadêmicas e, sobretudo, por ter acontecido um aparente desmonte dos instrumentos dessa política pública.

O referencial teórico selecionado representa uma importante contribuição que o autor desta dissertação traz para o campo da ciência ambiental. As reflexões da escola francesa de políticas públicas, especialmente a sociologia política, abrem possibilidades distintas das análises já realizadas. Especialmente quando consideradas as produções acadêmicas sobre o mesmo fenômeno político e social, a construção da política municipal de mudanças climáticas em São Paulo, nota-se que as teorias selecionadas nesta dissertação lançam um olhar diferente, que permite novas descobertas.

Desde o início já foi estabelecido que seriam feitas entrevistas semiestruturadas, de modo a obter informações qualificadas, que permitissem compreender o caso a partir das "lentes" das teorias selecionadas, além de complementar eventuais lacunas da produção acadêmica já existente. Assim, o primeiro passo para essa etapa do trabalho foi, a partir das leituras das produções existentes, de notícias da época e de documentos oficiais, identificar quem seriam os principais atores a serem entrevistados.

Feita essa identificação, o próximo passo foi ter clareza de quais teorias seriam utilizadas para o desenvolvimento do trabalho, de modo que você possível então elaborar o protocolo e roteiro de entrevistas (o roteiro encontra-se no anexo desta dissertação). Para aqueles em que não fora o caso, contou-se com a valiosa ajuda de Mônica Ribeiro, a qual esteve presente no governo durante o mandato do então Secretário Municipal do Verde e Meio Ambiente, Eduardo Jorge, de 2004 a 2012.

Feitas as entrevistas o autor tinha em mãos todos os materiais necessários para finalizar a elaboração de determinadas reflexões já iniciadas e avançar sobretudo nas análises finais e fechamento da dissertação. Esse percurso metodológico encontra-se organizado no quadro abaixo. 
Quadro 8. Percurso metodológico.

\begin{tabular}{|l|l|l|}
\hline Etapa & Descrição & Referências \\
\hline $\begin{array}{l}\text { Pressuposto preliminar } \\
\text { motivação inicial }\end{array}$ & $\begin{array}{l}\text { Importância do tema das mudanças climáticas e a } \\
\text { necessidade de abordar seus desafios a partir da } \\
\text { perspectiva dos governos locais }\end{array}$ & $\begin{array}{l}\text { Nobre } \text { et al.; Giddens; Matias; Da Veiga } \\
\text { Ostrom; Martins e Ferreira }\end{array}$ \\
\hline Definição do caso & $\begin{array}{l}\text { São Paulo é a primeira cidade brasileira a ter sua própria } \\
\text { política de mudança climática }\end{array}$ & - \\
\hline $\begin{array}{l}\text { Revisão não sistemática } \\
\text { da produção acadêmica }\end{array}$ & Investigação do que já existe sobre o caso selecionado & $\begin{array}{l}\text { Furriela; Cortese; Campos;Ramires; Back; } \\
\text { Landim }\end{array}$ \\
\hline $\begin{array}{l}\text { Recorte cronológico e } \\
\text { identificação dos } \\
\text { principais elementos } \\
\text { (atores, instituições, } \\
\text { ideias) }\end{array}$ & $\begin{array}{l}\text { Delimitação do período de criação da política, até sua } \\
\text { implementação e avaliação; Pesquisas prévias para } \\
\text { identificação dos principais acontecimentos e atores }\end{array}$ & $\begin{array}{l}\text { Pesquisas em sites, notícias, legislação e } \\
\text { documentos oficiais }\end{array}$ \\
\hline Referencial teórico & $\begin{array}{l}\text { Definição de qual "lente" será utilizada para observar o } \\
\text { caso }\end{array}$ & $\begin{array}{l}\text { Muller; Massardier; Palier e Surel; Lascoumes, } \\
\text { Le Galès e Simard }\end{array}$ \\
\hline Proposições & $\begin{array}{l}\text { Utilizadas como ferramenta auxiliar na construção das } \\
\text { reflexões }\end{array}$ & - \\
\hline Entrevistas & $\begin{array}{l}\text { Entrevistas semiestruturadas com atores-chave no processo } \\
\text { estudado }\end{array}$ & - \\
\hline Análise & Análise final após ter todo o material em mãos & - \\
\hline
\end{tabular}

Fonte: Elaboração do próprio autor. 


\subsection{Roteiro das entrevistas}

(i) Apresentação do propósito da dissertação

(ii) Autorização para gravação

0) Você poderia contar sua formação e trajetória profissional?

1) Quais foram as diferentes etapas de construção das políticas públicas de mudanças climáticas no município de São Paulo? (antes e depois da PMMC? Iniciou na gestão Serra/Kassab ou houve momentos importantes antes? Há uma quebra a partir da gestão Haddad?)

2) Considerando essas etapas, quais foram os principais atores de cada uma delas? (administração municipal, estadual, federal, academia, ONGs, associação de classe,...)

3) Para cada um desses atores, quais foram suas principais contribuições? (técnica, articulação política, financeira, científica, comunicação, engajamento social,...)

4) Como essas pessoas foram escolhidas? (Como ganharam voz?)

5) Como foi construída a minuta do Lei de Mudança do Clima e seu respectivo PL? Você participou desse processo?

6) O que a PMMC (Lei 14.933/2009) representou para a construção das diversas políticas públicas sobre mudanças climáticas?

7) Entre todas as ações, programas e políticas estabelecidos, cite três que você considera central para consolidar a agenda climática na cidade?

8) Como foi constituído o CMMCE em 2005 e 2009? Quem participou desse processo decisório?

9) Qual a importância do Comitê Municipal para o avanço das políticas sobre mudanças climáticas? O que mudou em seu funcionamento a partir das alterações de sua composição em setembro de 2009? (a presidência passa para a SMDU e a composição passa a contar com representantes fora da estrutura administrativa pública)

10) Qual o grau de relevância dos partidos e alianças políticas em relação à legitimação e possibilidade de avanços das políticas de mudanças climáticas? Essa variável foi determinante para a votação unânime e relativamente rápida do PL apresentado em agosto de 2008? (dez meses até a aprovação da lei em junho de 2009)

11) Quem, pessoa individual ou coletivo, foi essencial para a construção das políticas públicas de São Paulo sobre mudanças climáticas?

12) Você pode citar 3 nomes que julgue essencial para ser entrevistado? Qual motivo? 


\subsection{Lista dos entrevistados}

Os entrevistados foram selecionados a partir da identificação dos atores-chaves para o processo de construção da política climática paulistana.

As primeiras figuras foram os três secretários que estiveram à frente da SVMA entre os anos de 2001 a 2012. Uma vez que os principais avanços dessa agenda aconteceram durante os anos de 2005 a 2012, conforme descrito no capítulo 3, os demais entrevistados foram selecionados por conta da participação que tiveram em especial nesse período, sendo eles tanto figuras do governo, quanto de fora.

A última pergunta do roteiro de entrevista teve uma dupla função. Permitir avaliar se os entrevistados originalmente comporiam um mosaico suficiente para as entrevistas realizadas, o que se demonstrou assertivo. E, em segundo lugar, essa mesma pergunta permitiu aplicar a técnica de bola de neve, checando os nomes que se repetiam com maior frequência, auxiliando, portanto, a identificar os atores que compunham a rede de políticas públicas do mediador, descrita no capítulo 4.

De maneira geral, o roteiro para as entrevistas foi criado com o objetivo de reunir informações de ordem qualitativa que permitissem o autor desta dissertação compreender os motivos que influenciaram a adoção do discurso das mudanças climáticas como estratégia central da SVMA e de parte significativa do governo, os principais agentes e as funções que desempenharam, os instrumentos da ação pública que permitiram os avanços da agenda e as razões que impactaram o tempo de "vida útil" dessa política.

1. Adalberto Maluf, entrevista concedida via Skype em 12 de abril de 2018.

2. Adriano Diogo, entrevista concedida na Câmara Municipal cidade de São Paulo em 2 de outubro de 2017.

3. Eduardo Jorge, entrevista concedida na Secretaria Estadual de Saúde na cidade de São Paulo em 18 de julho de 2017.

4. Fabio Feldmann, entrevista concedida em seu escritório na cidade de São Paulo em 27 de março de 2018.

5. Hélio Neves, entrevista concedida na Secretaria Municipal de Saúde na cidade de São Paulo em 2 de agosto de 2017.

6. Gilberto Natalini, entrevista concedida na Câmara Municipal de São Paulo, em 14 de março de 2018. 
7. Laura Valente, entrevista concedida via Skype em 22 de setembro de 2017.

8. Mônica Ribeiro, entrevista concedida na cidade de São Paulo em 25 de março de 2017.

9. Rachel Biderman Furriela, entrevista concedida via Skype em 13 de setembro de 2017.

10. Ricardo Young, entrevista concedida via Zoom em 18 de julho de 2018.

11. Stela Goldenstein, entrevista concedida em sua residência na cidade de São Paulo em 4 de maio de 2017.

12. Volf Steinbaum, entrevista concedida em sua residência na cidade de Dourados (MS) em 23 de maio de 2017.

7.3. Atores que participaram da construção da política paulistana de mudanças climáticas

A presente seção tem a pretensão de registrar todos os nomes citados e encontrados durante o processo de elaboração desta dissertação, de modo que a lista abaixo possa servir de referência para os futuros trabalhos que pretendam compreender a construção da política paulistana de mudanças climáticas.

Entre os "alertas" que a abordagem teórica selecionada aponta está a trajetória de cada ator e sua influência no processo de produção de políticas públicas. Considerando esse aspecto, esse material auxilia igualmente a compreender a participação de cada ator, sua trajetória profissional e seus eventuais vínculos político-partidários.

Adalberto Maluf: Formado na primeira turma de relações internacionais da USP em 2005. Já no início do mandato de Serra na prefeitura, Adalberto integra a equipe da SMRI. Em janeiro de 2006, a partir de convite de Eduardo Jorge, Adalberto passa para a pasta da SVMA, sendo assessor do secretário para assuntos internacionais. Em agosto de 2007 Adalberto inicia seu enquanto diretor do C40 para São Paulo, cargo que ocupa durante os dois mandatos do prefeito Kassab e até a metade do mandato de Haddad, até julho de 2014.

Adriano Diogo: É geólogo sanitarista. Foi Secretário do Verde e Meio Ambiente do Município de São Paulo durante os anos de 2003 e 2004. Adriano Diogo foi o responsável pela contratação do inventário de emissões de gases de efeito estufa do município de São Paulo. Adriano Diogo é filiado ao Partido dos Trabalhadores (PT) e já exerceu o cargo de vereador de São Paulo entre 1998 a 2001 e de 2001 a 2002.

Alexandre Alves Schneider: Foi Secretário de Educação durante o mandato de Gilberto Kassab, de 2006 a 2011. Schneider é filiado ao Partido Social Democrata (PSD) e concorreu como vice- 
prefeito nas eleições municipais de outubro de 2012. Schneider teve papel importante na articulação com Eduardo Jorge para introdução da Carta da Terra na rede de escolas estaduais.

Alexandre de Moraes: Atual ministro do Supremo Tribunal Federal, Moraes ocupou o cargo de Secretário Municipal de Transportes de São Paulo de 2007 a 2010, acumulando simultaneamente a função de Secretário de Serviços de fevereiro de 2009 a junho de 2010.

Alfredo Cotait Neto: Engenheiro civil de formação é o atual presidente em exercício do PSD, partido de Gilberto Kassab. Na administração de Kassab na Prefeitura de São Paulo, Cotait exerceu o cargo de Secretário de Relações Internacionais de 2007, quando Helena Gasparian deixou o cargo, até 2012, ao final do mandato do então prefeito.

Ana Paula Garcia Martins: Citada na ata da 23a reunião do CMMCE como participante importante da elaboração do termo de referência para a contratação do $2^{\circ}$ inventário de gases de efeito estufa do município de São Paulo.

Aurélio Nomura: Vereador de São Paulo, tendo exercido sua quinta legislatura durante os anos de 2013 a 2016, sendo reeleito em 2017. Filiado ao PSDB, integra a Frente Parlamentar pela Sustentabilidade. Durante o governo de João Dória foi escolhido para ser líder do governo na Câmara Municipal.

Carlos Roberto Fortner: Engenheiro civil pela Escola Politécnica da USP. Possivelmente por conta de seu período na faculdade, desde então construiu uma relação próxima a Gilberto Kassab. Fortner foi Chefe de Gabinete da SVMA de janeiro de 2010 a julho de 2012, a partir do momento em que Hélio Neves se afastou do cargo para tratar do contrato da Prefeitura com a Controlar. De julho de 2012 até o final do mandato de Kassab em dezembro do mesmo ano, assumiu o cargo de Secretário do Verde e Meio Ambiente, quando Eduardo Jorge deixou a secretaria.

Eduardo Coelho e Mello Aulicino: Titular da SVMA no GT de Sustentabilidade na Construção dentro do CMMCE.

Eduardo Jorge Martins Alves Sobrinho: Médico sanitarista formado na Universidade Federal da Paraíba, especializou-se em medicina preventiva e saúde pública na Universidade de São Paulo entre os anos de 1974 e 1976. Durante a década de 1970, Eduardo Jorge teve uma participação política importante no movimento de saúde na Zona Leste de São Paulo, acompanhado de outros companheiros como Carlos Neder e Roberto Gouveia. Durante os anos de 1987 e 1988 foi Deputado Federal Constituinte. Foi Secretário de Saúde do município de São Paulo durante a gestão de Luiza Erundina (1989-1990) e Marta Suplicy (2001-2002). Foi Secretário do Verde e Meio Ambiente durante o mandato de José Serra/Gilberto Kassab (2005-2012). Eduardo Jorge 
deixou a SVMA em julho de 2012, 5 meses antes do término do mandato de Kassab, por conta de uma acusação não comprovada de irregularidade em processo de licenciamento ambiental. Foi fundador e filiado ao Partido dos Trabalhadores (PT) durante o período de 1980 a 2003. Em 2003 filiou-se ao Partido Verde (PV). Em 2014, Eduardo Jorge foi candidato à Presidência da República pelo PV.

Edsom Ortega Marques: Secretário Municipal de Segurança Urbana de São Paulo e Coordenador Executivo da Operação Defesa das Águas de maio de 2008 a 2012.

Elisabeth França: Secretária Municipal de Habitação (2010-2012) durante o período de realocação de populações em áreas de risco.

Francisco Vasconcelos: Vice-presidente do Sinduscon-SP durante a criação e regulamentação da "lei solar".

Fábio Feldmann: Foi Deputado Federal (PSDB) por três mandatos consecutivos (1986 - 1998) e participou como Deputado Constituinte (PMDB) na elaboração da Constituição de 1988, quando teve grande participação na criação do capítulo de meio ambiente na Constituição Federal. Em 1992, foi chefe da delegação brasileira dos parlamentares na Conferência das Nações Unidas sobre Meio Ambiente e Desenvolvimento - Rio 92. Feldman foi secretário estadual do meio ambiente de São Paulo de 1995 a 1998, no governo de Mário Covas (PSDB). De 1997 a 2002, foi membro oficial da delegação brasileira nas Conferências das Partes da Convenção Quadro das Nações Unidas sobre Mudanças Climáticas. De 2000 a 2004, foi secretário-executivo do Fórum Brasileiro de Mudanças Climáticas. De 2005 a 2010 foi secretário-executivo do Fórum Paulista de Mudanças Climáticas Globais e de Biodiversidade. Feldmann se candidatou a governador do estado de São Paulo pelo Partido Verde (PV) nas eleições de 2010.

Fernando de Mello Franco: Arquiteto, foi Secretário Municipal de Desenvolvimento Urbano durante toda a gestão Haddad (2013-2016).

Fernando Haddad: Professor universitário com formação em direito, mestrado em economia e doutorado em filosofia. Filiou-se ao PT em 1983. Haddad exerceu o cargo de subsecretário de Finanças e Desenvolvimento Econômico da cidade de São Paulo durante a gestão de Marta Suplicy (2001-2003), quando ambos eram do mesmo partido. Foi Secretário-Executivo do Ministério da Educação quando Tarso Genro chefiava a pasta (2003-2004) e então tornou-se Ministro da Educação (2005-2012) durante o governo de Luiz Inácio Lula da Silva. Foi prefeito de São Paulo de 2013 a 2016 e candidato a reeleição em 2016. 
Flavio Goldman: Diplomata do Itamaraty, Goldman foi Secretário-Adjunto na SMRI na época em que Cotait era o secretário, de 2007 a 2012.

Francisco Vidal Luna: Foi Secretário Municipal de Planejamento de São Paulo e presidente do Conselho Municipal de Política Urbana de 2005 a 2007. Foi um dos responsáveis pela venda no mercado internacional dos créditos de carbono advindos da captação de metano dos aterros sanitários.

Gilberto Kassab: Engenheiro civil pela Escola Politécnica da USP. Foi deputado federal pelo PFL durante duas legislaturas (1990-2003 e 2003-2007). Assumiu a Prefeitura de São Paulo em 2006 após o então Prefeito José Serra ter renunciado ao cargo. Em 2008 participou das eleições municipais quando então ganhou em segundo turno e assumiu a prefeitura até 2012. Kassab foi filiado ao Partido da Frente Liberal (PFL) de 1995 a 2007, quando então o partido mudou de nome para Democratas (DEM), partido ao qual ficou filiado até 2011. Em março de 2011, Kassab saiu do DEM para criar o Partido Social Democrático (PSD) onde é o atual presidente do partido.

Gilberto Natalini: Médico de formação, iniciou sua participação política na década de 1970 durante a ditadura militar. Foi Secretário Municipal de Saúde de Diadema (1997-2000). Natalini iniciou seu primeiro mandato como Vereador na Câmara Municipal de São Paulo em 2001, e em 2016 venceu mais uma eleição, dando início ao seu quinto mandato consecutivo como Vereador. Exerceu o cargo de Secretário do Verde e Meio Ambiente do Município de São Paulo de janeiro a agosto de 2017, durante a gestão do Prefeito João Doria (PSDB). Natalini foi filiado ao PSDB de 2000 a 2011, e desde sua saída do PSDB passou a ser filiado ao PV. Natalini também foi um dos integrantes da Frente Parlamentar pela Sustentabilidade na Câmara Municipal de São Paulo, exercendo sua presidência durante o ano de 2015.

Gil Scatena: Assessor de Planejamento Urbano de março de 2013 a novembro de 2014 durante o mandato do vereador Ricardo Young (PPS/Rede).

Helena Maria Gasparian: Diplomata de carreira, foi Secretária Municipal de Relações Internacionais de 2005 a 2007. Helena foi uma das responsáveis pela organização de viagem de comitiva oficial da Prefeitura de São Paulo à Londres, para conhecerem as experiências na agenda climática da capital do Reino Unido.

Hélio Neves: Médico especialista em Saúde Pública pela USP. Desde o período de faculdade Hélio já se aproximou do grupo de Eduardo Jorge e dos demais médicos que atuavam fortemente na Zona Leste (Carlos Neder e Roberto Gouveia). Dirigiu a Coordenadoria de Vigilância em Saúde da Secretaria Municipal da Saúde de São Paulo (2002-2004) e foi chefe de gabinete da SVMA 
durante a gestão de Eduardo Jorge (2005-2010). De 2010 a início de 2012 Hélio ficou responsável pela revisão do contrato da Prefeitura de São Paulo e a empresa Controlar, responsável pela inspeção veicular. No início de 2012 Hélio deixou a SVMA.

Jilmar Tatto: Filiado ao PT desde 1984, foi deputado estadual na década de 1990, secretário de Transportes na gestão de Marta Suplicy (2001-2004) e Fernando Haddad (2013-2016).

João Castro: Engenheiro químico representante do consórcio Geoklock-Ekos, vencedor da licitação para elaboração do $2^{\circ}$ inventário de emissões de gases de efeito estufa do município de São Paulo.

José Eduardo Cardozo: Advogado e político brasileiro filiado ao PT desde 1980. Foi Secretário Municipal de Governo de São Paulo na gestão de Luiza Erundina (PT) de 1989 a 1992. Durante o mandato de Marta Suplicy, então do mesmo partido, na Prefeitura de São Paulo de 2001 a 2004, Cardozo atuou em várias ocasiões assessorando a prefeita, ainda que não tivesse um cargo formalizado na administração municipal. Nesse período, destaca-se o assessoramento na estruturação jurídica do contrato de inspeção veicular. Posteriormente, viria a ser Ministro de Justiça de 2011 a 2016, nos governos Lula e Dilma e Advogado-Geral da União no mandato de Dilma.

José Goldemberg: Durante o governo do Presidente Fernando Collor de Mello, exerceu os cargos de Secretário da Ciência e Tecnologia (1990-1991), Ministro da Educação (1991-1992) e Secretário do Meio Ambiente (março a julho de 1992). Goldemberg foi um dos responsáveis, ao lado de Celso Lafer e José Lutzemberger, pela organização da Rio 92, fórum internacional, no Brasil, considerada um marco importante para a agenda climática. Foi Secretário de Meio Ambiente do estado de São Paulo de 2002 a 2006, durante o governo de Geraldo Alckmin.

José Police Neto: Foi presidente do Diretório Municipal do PSDB na capital paulista de 2000 a 2002. Assumiu seu primeiro mandato como vereador da cidade de São Paulo em 2005, pelo PSDB. Licenciou-se do cargo em 2006, assumindo a Secretaria Municipal de Participação e Parceria. Retornou à Câmara em 2007 e foi Líder do Governo Gilberto Kassab entre 2007 e 2010. Filiou-se ao PSD em 2011. Durante a gestão do prefeito Fernando Haddad exerceu seu segundo mandato como vereador da cidade de São Paulo. Atualmente está em seu terceiro mandato (2017-2020). Neto é integrante da Frente Parlamentar pela Sustentabilidade.

José Tadeu Candelária: Economista de formação e filiado ao Partido Republicano (PR). Candelária ocupou o cargo de secretário na SVMA de junho de 2015 a dezembro de 2016, a partir de uma indicação do então Ministro dos Transportes (Antônio Carlos Rodrigues) durante a gestão de 
Fernando Haddad (PT). À época, Candelária era também o presidente estadual do PR. Candelária já havia sido candidato a $1^{\circ}$ suplente do então senador Eduardo Suplicy (PT) nas eleições de 2014. José Serra: Em 1988 foi um dos fundadores do Partido da Social Democracia Brasileira (PSDB). Eleito a Prefeito de São Paulo para iniciar o mandato em 2005, tendo como vice-Prefeito Gilberto Kassab (PFL). Em março de 2006 renunciou ao governo de São Paulo para concorrer à eleição de governador do estado de São Paulo, quando ganhou no primeiro turno. Renunciou ao cargo de governador em abril de 2010 para concorrer pela segunda vez à presidência da república.

Laura Lúcia Ceneviva: Citada na ata da $23^{\text {a }}$ reunião do CMMCE como participante importante da elaboração do termo de referência para a contratação do $2^{\circ}$ inventário de gases de efeito estufa do município de São Paulo.

Laura Valente: Exerceu o cargo de Diretoria Regional para América Latina e Caribe da ONG Iclei (2003-2011).

Leda Maria Aschermann: Filiada ao PV, foi suplente de Eduardo Jorge no CMMCE.

Leonardo Osvaldo Barchini Rosa: Foi Secretário de Relações Internacionais e Federativas da Prefeitura de São Paulo (2013-2015) e chefe de gabinete do Prefeito Fernando Haddad em seu último ano de mandato, em 2016.

Luiz Ricardo Pereira Leite: Foi Secretário Municipal de Habitação de São Paulo de 2010 a 2012.

Marcelo Cardinale Branco: Secretário Municipal de Infraestrutura e Obras (2006-2010), durante a criação da "lei solar", e Secretário Municipal de Transportes (2010-2012) após a implementação da inspeção veicular e ecofrota. Branco já havia sido presidente da Companhia de Desenvolvimento Habitacional e Urbano (CDHU), além de ter bons relacionamentos com atores do PSDB e pessoalmente com o então prefeito Kassab.

Maria de Fátima Andrade: Professora representante do consórcio Geoklock-Ekos, vencedor da licitação para elaboração do $2^{\circ}$ inventário de emissões de gases de efeito estufa do município de São Paulo.

Marta Suplicy: Foi filiada ao Partido dos Trabalhadores (PT) de 1981 a 2015. Foi Prefeita de São Paulo durante o mandato de 2001 a 2004, tendo como vice-prefeito Hélio Bicudo, ganhando a disputa contra Paulo Maluf (PPB). Disputou a reeleição para a prefeitura de São Paulo em outubro de 2004, quando perdeu no segundo turno para José Serra.

Mônica Ribeiro: Coordenadora de comunicação corporativa e relações com a mídia da Secretaria do Verde e Meio Ambiente durante o período de 2005 a 2012. Mônica co-organizou o livro "Três ou quatro sementes de araçá: coletânea de artigos de Eduardo Jorge Alves Sobrinho". Mônica tem 
formação em jornalismo e iniciou sua trajetória na agenda do meio ambiente em 2001 no Jornal da Tarde, iniciativa em parceria da SVMA e SMA. Em seguida Mônica também trabalhou na Boitempo Editorial. Especificamente na gestão pública, Mônica iniciou sua carreira a partir do convite da então Secretária do Verde e Meio Ambiente, Stela Goldenstein, em 2002, passando a exercer a função de assessora de gabinete da secretária. Quando Stela deixa a secretaria em novembro de 2002, a SVMA passa a ser coordenada por Adriano Diogo até o final de 2004 e Mônica desenvolvera então um trabalho mais relacionado ao Departamento de Controle da Qualidade Ambiental (Decont). Após as eleições de 2004, e com a vitória de José Serra, Eduardo Jorge passa a comandar os trabalhos na SVMA e Mônica também seguira a contribuir na secretaria. Mônica e Eduardo Jorge se conhecem desde então e, uma aproximação entre os dois começa a se desenvolver, fazendo com que Mônica passasse a coordenar toda a parte de comunicação da SVMA. Inclusive, quando Eduardo Jorge é lançado candidato à Presidência da República em 2014, Mônica Ribeiro também esteve à frente da comunicação da campanha. Mônica não tem nenhuma filiação partidária.

Miguel Luiz Bucalem: Formado em engenharia civil pela Escola Politécnica da Universidade de São Paulo. Secretário de Desenvolvimento Urbano (2009-2012), que viria a se filiar ao Partido Social Democrático (PSD) criado pelo ex-prefeito Gilberto Kassab em 2011. Miguel exerceu o cargo de Presidente do Comitê Municipal de Mudança do Clima e Economia durante o período de 2009 a 2012.

Nabil Bonduki: Foi Vereador de São Paulo pelo PT de 2013 a 2016. Foi secretário da Frente Parlamentar pela Sustentabilidade e integrante Fórum Suprapartidário por uma São Paulo Saudável e Sustentável.

Oswaldo Massambani: Professor Titular do IAG/USP, participou da coordenação na elaboração das diretrizes para o plano de ação de SP para mitigação e adaptação às mudanças climáticas, publicado em 2011.

Patrícia Marra Sepe: geóloga de formação, funcionária de carreira na Prefeitura de São Paulo. Foi Chefe de Gabinete de Adriano Diogo na SVMA (2002-2004). Patrícia foi Suplente da SVMA dentro do GT Sustentabilidade e Uso do Solo no CMMCE. Patrícia representa um ator chave, uma vez que esteve na SVMA nas gestões de Marta, Serra e Kassab e na SDMU, que exercia a presidência do CMMCE, na gestão Haddad.

Paulo Carrara de Castro: Médico, membro do Departamento de Saúde Coletiva da Faculdade de Ciências Médicas da Santa Casa de São Paulo. Paulo Carrara teve participação relevante durante 
a gestão de Eduardo Jorge na SVMA, especialmente nas explicações científicas a respeito do impacto das mudanças climáticas na saúde pública.

Paulo Saldiva: Médico e professor livre docente da USP. Saldiva teve participação relevante na argumentação a respeito dos danos à saúde pública que as emissões de GEEs de automóveis causam, tendo dado entrevista a vários veículos de comunicação na época da implantação da inspeção veicular em São Paulo.

Rachel Biderman Furriela: Integrante da equipe do Centro de Estudos em Sustentabilidade da Fundação Getúlio Vargas (Gvces) durante os anos de 2004 a 2011, participou do processo de elaboração do $1^{\circ}$ inventário de emissões do município de São Paulo. Rachel teve participação relevante na construção do anteprojeto de lei da Política Municipal do Clima e no seu aprimoramento junto à Secretaria de Governo nos anos de 2008 e 2009.

Ricardo Teixeira: No período de 2005 a 2007, durante a gestão Serra/Kassab, Ricardo, então filiado ao PSDB, foi Chefe de Gabinete e Secretário Adjunto da Secretaria de Coordenação das Subprefeituras. Em 2008 foi eleito vereador pelo PSDB. Em 2012, foi reeleito vereador de São Paulo, agora pelo PV. Em 2013, quando iria iniciar sua vereança, foi convidado a assumir a SVMA, cargo que ocupou até janeiro de 2014. Durante o trabalho na SVMA, Ricardo foi responsável pelo fim da CONTROLAR, empresa responsável pelo programa de controle de emissões de automóveis. De 2015 a 2016 esteve à frente da Secretaria Municipal de Coordenação das Subprefeituras. Em 2016 concorreu novamente às eleições e foi eleito vereador de São Paulo, agora pelo PROS, sendo também o presidente municipal do partido.

Ricardo Young: Foi eleito Vereador de São Paulo pelo PPS nas eleições de 2012 e exerceu o mandato de 2013 a 2016, durante a gestão do prefeito Fernando Haddad. Em 2013 foi um dos criadores da Frente Parlamentar pela Sustentabilidade, da qual foi presidente durante os anos de 2013, 2014 e 2016. Em fevereiro de 2016 Young deixa o PPS e passa a ser membro fundador da Rede Sustentabilidade, sendo o único deste ultimo na Câmara Municipal de São Paulo. Young foi o autor do PL 167/2015 que propunha a compensação da emissão de GEEs de grandes eventos.

Rita de Cássia Ogera: Citada na ata da $23^{\mathrm{a}}$ reunião do CMMCE como participante importante da elaboração do termo de referência para a contratação do $2^{\circ}$ inventário de gases de efeito estufa do município de São Paulo.

Rose Marie Inojosa: Diretora da Universidade Aberta do Meio Ambiente e Cultura de Paz (Umapaz) de 2006 a 2012. Rose foi suplente da SVMA no GT Sustentabilidade no Gerenciamento de Resíduos no CMMCE. 
Sérgio Watanabe: Presidente do Sinduscon-SP durante a criação e regulamentação da "lei solar". Stela Goldenstein: Geógrafa, Stela teve uma série de passagens na gestão estadual e municipal de São Paulo, trabalhando sobretudo com os temas de meio ambiente, recursos hídricos e habitação. Durante a gestão do Governador Mário Covas (PSDB), Stela foi Secretária Adjunta na Secretaria do Meio Ambiente (1995-1998), quando Fábio Feldman ocupava a chefia da Secretaria. Após a saída de Feldman, Stela passou a ser a Secretária Estadual do Meio Ambiente (1998-1999). Durante parte do mandato de Marta Suplicy (PT) na Prefeitura de São Paulo, Stela foi Secretária do Verde e Meio Ambiente, de 2001 a novembro de 2002. Após sua saída, Adriano Diogo (PT) assumiu a SVMA. Nos anos de 2003 e 2004 Stela atuou na iniciativa privada em sua própria consultoria. Durante o período de 2005 a 2008, Stela foi Secretária Adjunta de Governo e Assessora do Prefeito, nos mandatos de José Serra (PSDB) e Gilberto Kassab (PFL), e teve importante participação na construção e negociação do PL 530/08, que propunha a criação da Política Municipal de Mudança do Clima. De 2008 a 2010 Stela foi Assessora do Governador José Serra.

Tatiana Tucunduva Cortese: Representante do gabinete do vereador Gilberto Natalini no CMMCE. Tatiana é também autora da tese de doutorado "Mudanças climáticas na cidade de São Paulo: avaliação da política pública municipal”, publicada em 2013 pela Faculdade de Saúde Pública da USP.

Toninho Vespoli: Vereador de São Paulo pelo PSOL, Vespoli foi integrante da Frente Parlamentar pela Sustentabilidade durante a gestão de Fernando Haddad.

Volf Steinbaum: Em sua adolescência, Volf foi filiado ao Partido Socialista Brasileiro (PSB), além de ter participado do ato de fundação do Partido dos Trabalhadores (PT), apesar de nunca ter sido filiado a este último. Graduado em Ciências Sociais, trabalhou como jornalista nos jornais Estado de São Paulo e Folha de São Paulo durante alguns anos da década de 1960. Após esse período, Volf trabalhou na consultoria ASPLAN - Assessoria em Planejamento S.A., quando participou da elaboração do $1^{\circ}$ plano urbanístico de São Paulo, lançado em 1968. Durante o ano de 1974, Volf passou alguns meses estudando em Edimburgo, na Escócia, quando teve a oportunidade de acompanhar algumas pesquisas científicas que já tratavam das questões climáticas. Ao retornar ao Brasil, trabalhou com planejamento urbano na cidade de São Bernardo do Campo. Em seguida trabalhou na Secretaria de Planejamento da cidade de São Paulo, quando Candido Malta Campos Filho era o Secretário. Após esse período, Volf entrou para o quadro da Cetesb, Companhia Ambiental do Estado de São Paulo, instituição vinculada à Secretaria Estadual de Meio Ambiente 
atuando nos setores de transporte e qualidade do ar. Após essas experiência foi trabalhou como diretor da Emplasa, empresa pública preocupada com o desenvolvimento e planejamento das cidades da RMSP. Durante essa experiência também teve a oportunidade de investigar e compartilhar conhecimentos com algumas experiências internacionais que já estavam mais avançadas em políticas climáticas. Quando retornou à Cetesb, exercia o cargo de assessor à Presidência, e foi consultado para auxiliar na construção do termo de referência para contratação do inventário de emissões do município de São Paulo, no ano de 2002. Volf foi responsável pelo Programa de Qualidade do Ar e Coordenador do Programa de Inspeção Veicular, ambos da SVMA, durante a gestão de Eduardo Jorge. Secretário-Executivo do Comitê Municipal de Mudança do Clima e Ecoeconomia no período de 2009 a 2012. Volf co-organizou o livro "Três ou quatro sementes de araçá: coletânea de artigos de Eduardo Jorge Alves Sobrinho. Volf saiu da vida pública após o ano de 2012, quando desde então lecionou na Universidade Católica de Santos, se aposentando em 2016.

Xico Graziano: Agrônomo de formação, Graziano ocupou vários cargos políticos, sendo filiado ao PSDB. Em 1995 foi presidente do Instituto Nacional de Colonização e Reforma Agrária (INCRA), depois assumiu a Secretaria Estadual de Agricultura (1996-1998), então elegeu-se a deputado federal pelo PSDB/SP (1998-2006). De 2007 a 2010 foi Secretário Estadual de Meio Ambiente, momento em que teve de negociar com Eduardo Jorge as compensações ambientais ao município de São Paulo que seriam incorporadas ao licenciamento ambiental da ampliação das faixas de rolamento da via Marginal do Rio Tietê. Essa negociação e a compensação ambiental permitiu o plantio de 83 mil árvores ao longo do rio e a retomada das obras do Parque Linear da APA do Tietê, dando origem ao maior parque linear do mundo a época, com a construção de uma estrada-parque e uma ciclovia de $14 \mathrm{~km}$.

Wanderley Meira do Nascimento: Arquiteto, filiado ao PT e integrante da corrente "Novo Rumo" deste partido. Wanderley trabalhou na gestão municipal durante o mandato de Luiza Erundina (1889-1992) quando esta também era do PT. Wanderley ocupou o cargo de secretário na SVMA de fevereiro de 2014 a junho de 2015. 